UNIVERSITÉ DU QUÉBEC À CHICOUTIMI

MEMOIRE PRESENTÉ À

L'UNIVERSITÉ DU QUÉBEC À CHICOUTIMI COMME EXIGENCE PARTIELLE DE LA MAITRISE EN SCIENCES DE LA TERRE LAKE FORMATIONS, SLAVE PROVINCE, NORTHWEST TERRITORIES

\author{
Par \\ Clarence Pickett
}

Mai 2002

Droits réservés 


\section{Bibliothèque}

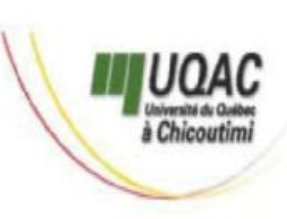

\section{Mise en garde/Advice}

Afin de rendre accessible au plus Motivated by a desire to make the grand nombre le résultat des results of its graduate students' travaux de recherche menés par ses research accessible to all, and in étudiants gradués et dans l'esprit des accordance with the rules règles qui régissent le dépôt et la governing the acceptation and diffusion des mémoires et thèses diffusion of dissertations and produits dans cette Institution, theses in this Institution, the I'Université du Québec à Université du Québec à Chicoutimi (UQAC) est fière de Chicoutimi (UQAC) is proud to rendre accessible une version make a complete version of this complète et gratuite de cette œuvre. work available at no cost to the reader.

L'auteur conserve néanmoins la The author retains ownership of the propriété du droit d'auteur qui copyright of this dissertation or protège ce mémoire ou cette thèse. thesis. Neither the dissertation or Ni le mémoire ou la thèse ni des thesis, nor substantial extracts from extraits substantiels de ceux-ci ne it, may be printed or otherwise peuvent être imprimés ou autrement reproduced without the author's reproduits sans son autorisation. permission. 


\title{
A SEDIMENTARY FACIES ANALYSIS OF THE $>2.8$ GA BENIAH AND BELL LAKE FORMATIONS, SLAVE PROVINCE, NORTHWEST TERRITORIES
}

\begin{abstract}
RÉSUMÉ
La Province des Esclaves, située dans les Territoires du Nord-Ouest, possède plusieurs dépôts sédimentaires de plate-forme d'âges archéens (2,8-2,9 Ga) adjacents à des zones de failles d'extension régionale d'orientation nord-sud. Les bassins sédimentaires comprennent des quartzarénites, c'est-à-dire des grès minéralogiquement matures qui se forment dans des conditions climatiques, hydrauliques et tectoniques particulières. Ces roches sédimentaires sont interprétées comme ayant été déposées en discordance sur un complexe lité mafique et des gneiss tonalitiques à granodioritiques et elles sont recouvertes par des roches volcaniques mafiques et felsiques de 2,6-2,7 Ga.

La Formation de Beniah qui se trouve à environ $150 \mathrm{~km}$ au nord-est de la ville de Yellowknife a une épaisseur de 100 à 1000 mètres et est composée de quatre lithofaciès distincts. Ces lithofaciès sont: 1) des conglomérats de 2 à $13 \mathrm{~m}$ d'épaisseur, 2) des quartzarénites de 10 à $120 \mathrm{~m}$ d'épaisseur, 3) des grès-siltstones de 10 à $16 \mathrm{~m}$ d'épaisseur et 4) des siltstone-grès de 5 à $13 \mathrm{~m}$ d'épaisseur. Le lithofaciès de conglomérat se subdivise en deux sous-lithofaciès soit celui de conglomérat à cailloux de quartz et celui de brèche sédimentaire. Le lithofaciès de siltstone-grès regroupe le sous-lithofaciès de siltstone à litage ondulé et planaire et le sous-lithofaciès de formation de fer. Localement, les roches volcaniques et volcanoclastiques sont en contact dépositionnel avec les roches sédimentaires de la Formation de Beniah. Ces roches volcaniques sont considérées comme représentant la stratigraphie de la partie supérieure de la formation.

La géométrie tabulaire des lithofaciès, la présence de lits entrecroisés composites, les patrons de paléocourants bimodaux et bipolaires et l'abondance des films d'argile suggèrent que les roches sédimentaires de la Formation de Beniah se sont déposées dans un environnement influencé par la marée. De plus, les lits granoclassés, l'alternance entre certains lits de grès et siltstone et les rides superposées sur le flanc des lits entrecroisés indiquent une faible influence des courants de tempêtes et des vagues. L'environnement de déposition proposé est celui d'un milieu sous-marin de faible profondeur d'un complexe estuaire qui contient: 1) des barres de gravier côtières (le lithofaciès de conglomérat), 2) des coulées de débris (lithofaciès de brèche sédimentaire), 3) une série de chenaux de marées(lithofaciès de siltstone-grès et grès-siltstone), 4) des bancs de sable le long de l'avant-plage (lithofaciès de quartzarénite) et 5) des sédiments hétérolithiques et sédiments à grain fin déposés en suspensiọn à la transition entre l'avant-plage inférieure et la haute mer (lithofaciès de grès-siltstone et sous-lithofaciès de formation de fer).
\end{abstract}


Les informations supplémentaires apportées par la Formation de Bell Lake (environ 45 $\mathrm{km}$ au nord de Yellowknife) indiquent la présence des trois lithofaciès, suivant: 1) quartzarénite de 2 à $10 \mathrm{~m}$ d'épaisseur, 2) grès-siltstone de 1 à $12 \mathrm{~m}$ d'épaisseur et 3) formation de fer de moins de 1 à $30 \mathrm{~m}$ d'épaisseur. L'abondance des laminations parallèles et des lits entrecroisés de faible pente en forme de lits tabulaires peu épais sont caractéristiques des dépôts de milieu de plate-forme non protégée. Ce milieu fourni des conditions favorabled pour la formation de grès en feuillets (sheet sandstones) influencés par la combinaison de changement dans la marée, les vagues et les tempêtes. La pétrographie et la cartographie suggèrent une discordance plutôt qu'un contact intrusif entre le socle granitique et les roches sédimentaires sus-jacentes.

L'empilement des lithofaciès de la Formation de Beniah indique la présence de plusieurs séquences négatives de 10 à 110 mètres de puissance. Cette répétition séquentielle des lithofaciès commence avec le siltstone-grès à la base, suivi du grès-siltstone au milieu, puis de la quartzarénite ou localement du conglomérat au sommet. Un contact net entre la quartzarénite ou le conglomérat et le siltstone-grès indique le commencement d'une nouvelle succession. La formation de ces successions négatives est attribuée à la combinaison d'une variation eustatique du niveau de la mer et d'une activité tectonique. Le tectonisme semble avoir une importance considérable dans le développement de la Formation de Beniah. La présence des complexes lités mafiques, les séquences négatives des roches sédimentaires, l'abondance des dykes et le volcanisme syn-sédimentaire suggèrent un environnement d'extension. Le modèle tectonique proposé pour la Formation de Beniah et pour d'autres successions de quartzarénite similaires dans la Province des Esclaves (incluant la Formation de Bell Lake et des roches sédimentaires des lacs Patterson, Brown et Winter) implique la présence, il y a 3 milliards d'années, d'un protocontinent de grande étendue formé de tonalite et granodiorite. L'amincissement de la croûte par l'extension et le rifting aurait permis la mise en place des complexes ignés stratiformes. Les failles majeures à grande échelle formées à la suite de l'amincissement de la croûte et le déplacement des blocs ainsi créés ont généré les bassins où les séquences négatives ont pu se développer. L'atténuation subséquente et la séparation du proto- continent ont permis la mise en place des séquences volcaniques subaquatiques aux environs de $2,8 \mathrm{Ga}$.

L'accumulation des quartzarénites des Formations de Beniah et de Bell Lake implique un climat tropical avec des concentrations élevées de $\mathrm{CO}_{2}$ et des températures élevées. De plus, un système plus dynamique entre la terre et la lune pendant l'Archéen en conjonction avec un milieu sédimentaire à haute énergie ont pu favoriser le développement des grès très riche en quartz.

Les successions sédimentaires archéennes riches en quartz existent partout dans le monde. Le Craton du Zimbabwe en Afrique, le Craton de Dharwar en Inde et la Province du lac Supérieur du bouclier Canadien en sont des exemples. La lithostratigraphie et l'environnement de déposition pour ces successions sont comparables à ceux des Formations de Beniah et de Bell Lake. Des épisodes de rifting ont également été interprétés pour chacune de ces régions, suggérant ainsi la possibilité d'un événement tectonique majeur et mondial aux environs de 2,8-3,0 Ga sur l'ensemble de la croûte continentale juvénile de la Terre. 


\title{
A SEDIMENTARY FACIES ANALYSIS OF THE $>2.8$ GA BENIAH AND BELL LAKE FORMATIONS, SLAVE PROVINCE, NORTHWEST TERRITORIES
}

\begin{abstract}
The Slave Province, located in the Northwest Territories, hosts a number of Archean shelf-type sedimentary successions (ca. 2.8-2.9 Ga) that lie adjacent to major, northtrending crustal-scale lineaments. These basins contain mineralogically mature quartzarenites that have formed under specific climatic, hydraulic and tectonic conditions. The sedimentary rocks unconformably overlie $>3.0$ Ga tonalite-granodiorite basement and layered igneous complexes and are overlain by 2.6-2.7 Ga mafic and felsic volcanic rocks.

The 100 to 1000 m-thick Beniah Formation $(-150 \mathrm{~km}$ northeast of Yellowknife, NWT) contains four distinct lithofacies including: 1) the 2-13 m-thick conglomerate (CL), 2) the 10-120 m-thick quartz-arenite (QAL), 3) the 10-16-m-thick sandstone-siltstone (SaSL) and 4) the 5-13 m-thick siltstone-sandstone (SiSL) lithofacies. The conglomerate lithofacies is subdivided into the quartz-pebble conglomerate (QPSL) and sedimentary breccia sublithofacies (SBSL). The siltstone-sandstone lithofacies contains both the wavyto planar-bedded (WPSL) and iron-formation (IFSL) sublithofacies. Minor volcanic and volcaniclastic rocks locally indicate conformable depositional contacts with the underlying sedimentary rocks and represent the upper-most stratigraphic level of the Beniah Formation.

The ubiquitous tabular geometry of the lithofacies, the multiform composite crossstrata, bimodal/bipolar paleocurrent patterns and abundance of mudstone drapes strongly support tidal influence for the Beniah Formation with evidence of lesser wave and storm activity. Deposition occurred in a shallow marine estuarine/embayment complex containing: 1) coastal gravel bars within an embayment and along a shoreline (QPSL), 2) local debris flow deposits (SBSL), 3) a series of tidal channels and shoals (SaSL \& WPSL), 4) migrating sandwaves along the shoreface (QAL) and 5) heterolithic sediments deposited in a deeper, transitional lower shoreface to offshore setting (WPSL/IFSL \& SaSL).

Supplementary data from the Bell Lake Formation ( $45 \mathrm{~km}$ north of Yellowknife) revealed three distinct lithofacies: 1) the 2-10 m-thick quartz-arenite, 2) the 1-12 m-thick sandstone-siltstone and 3) the 0.5-30 m-thick iron formation lithofacies. The abundance of parallel laminae and low-angle cross-laminae bounded by thin, extensive tabular beds are characteristic of a coastal depositional setting open to the ocean, providing favourable conditions to form sheet sandstones under the influence of tides, waves and possible storms. Petrography coupled with field evidence advocates an unconformable, rather than intrusive contact between the basement and overlying Bell Lake Formation.

Lithofacies stacking in the Beniah Formation reveals the presence of up to 12 coarsening-upward sequences (10-105 $\mathrm{m}$ thick) that begin with a basal SiSL, grading upward into the SaSL and terminating with the QAL or CL. A sharp contact between the QAL (or CL) and the SiSL marks the commencement of a new sequence. The upwardcoarsening sequences have been attributed to a combination of eustatic sea level change
\end{abstract}


and tectonic activity. The role of tectonism was significant in the development of the Beniah Formation. The presence of layered intrusions, upward-coarsening sedimentary cycles, the abundance of cross-cutting mafic dykes and contemporaneous volcanism strongly support extension. The proposed model for the Beniah Formation and for similar quartz-arenite sequences throughout the Slave Province (including Bell Lake, Patterson, Brown and Winter lakes) presupposes the presence of an extensive proto-continental crust of tonalite and granodiorite $\sim 3.0$ billion years ago. Crustal attenuation from extension and rifting allowed for the emplacement of layered igneous complexes. Large crustal-scale faults developed in response to crustal thinning, thus forming topographic lows where sediment accumulated in shallow marine basins. Subsequent episodes of extension resulted in flooding of the basin and the development of upward-coarsening sedimentary cycles. Continued crustal attenuation and break-up of the proto-continent resulted in subaqueous effusive volcanism covering the sedimentary succession at about $2.8 \mathrm{Ga}$.

The accumulation of the quartz-arenites from the Beniah and Bell Lake formations imply a tropical-like climate due to high $\mathrm{CO}_{2}$ levels and elevated surface temperatures. A more dynamic Earth-Moon system in the Archean combined with a high-energy environment resulted in the development of these extremely quartz-rich sandstones.

Archean quartz-rich sedimentary successions from the Zimbabwe Craton of Africa, the Indian Dharwar Craton and the Superior Province of the Canadian Shield are comparable to the Beniah and Bell Lake formations in both lithology and depositional setting. In addition, episodic rifting has been inferred for each of these areas, thus alluding to the possibility of a major, worldwide tectonic event that transpired 2.8-3.0 billion years ago on parts of the Earth's earliest continental crust. 
TABLE OF CONTENTS

RÉSUMÉ ii

ABSTRACT iv

TABLE OF CONTENTS vi

LIST OF FIGURES

LIST OF PLATES

LIST OF TABLES xiii

ACKNOWLEDGEMENTS xiv

1. INTRODUCTION 1

1.1. Introduction 1

1.2. Methodology 2

1.3. Geological Setting 4

1.3.1. Regional Geology 4

1.3.2. Yellowknife Volcanic Belt Stratigraphy 7

1.3.3. Local Geology 10

1.4 Characteristics and Origin of Quartz-Arenites 13

2. LITHOFACIES DISTINCTION 19

2.1. Introduction 19

2.2. Sedimentary Lithofacies $\quad 21$

2.2.1. Conglomerate Lithofacies 21

2.2.2. Interpretation 27

2.2.3. Quartz-Arenite Lithofacies 30

2.2.4. Interpretation 33

2.2.5. Sandstone-Siltstone Lithofacies 40

2.2.6. Interpretation 43

2.2.7. Siltstone-Sandstone Lithofacies 45 
2.2.8. Interpretation $\quad 50$

2.3. Relationship Between Volcanic and Sedimentary Rocks 54

2.4. Cross-Cutting Mafic Dykes 56

2.5. Petrography of the Lithofacies 61

2.5.1. Conglomerate Lithofacies 61

2.5.2. Quartz-Arenite Lithofacies 62

2.5.3. Sandstone-Siltstone Lithofacies $\quad 62$

2.5.4. Siltstone-Sandstone Lithofacies 66

$\begin{array}{ll}\text { 2.6. Interpretation of Petrography } & 67\end{array}$

3. BELL LAKE FORMATION 69

3.1. Introduction $\quad 69$

3.2. Local Geology 69

3.3. Lithofacies Distinction 71

3.3.1. Quartz-Arenite Lithofacies 71

3.3.2. Sandstone-Siltstone Lithofacies 76

3.3.3. Iron-Formation Lithofacies $\quad 80$

3.4. Petrography of the Lithofacies 80

3.5. Stratigraphic Correlation of the Bell Lake Formation 85

3.6. Basement and Cover Sequence Relationship 87

4. LITHOFACIES ANALYSIS 95

4.1. Introduction 95

4.2. Association of Lithofacies: Beniah Lake 95

4.3. Facies Successions: Beniah Lake 99

4.3.1. Significance of Coarsening-Upward Successions 103

4.4. Depositional Setting: Beniah Lake 105

4.5. Lithofacies Analysis of Bell Lake Formation 107 
$\begin{array}{ll}\text { 5. DISCUSSION/CONCLUSIONS } & 109\end{array}$

$\begin{array}{ll}\text { 5.1. Introduction } & 109\end{array}$

$\begin{array}{ll}\text { 5.2. Provenance } & 109\end{array}$

5.3. Tectonic Influence on Sedimentation 111

5.3.1. Tectonism and Basin Development $\quad 112$

5.4. Paleogeographic Reconstruction 115

$\begin{array}{ll}\text { 5.4.1. Beniah Formation } & 115\end{array}$

$\begin{array}{ll}\text { 5.4.2. Bell Lake Formation } & 117\end{array}$

$\begin{array}{ll}\text { 5.5. Archean Analogues } & 117\end{array}$

$\begin{array}{ll}\text { 5.5.1. Correlative Stratigraphy } & 121\end{array}$

5.6. Archean Climate and Atmospheric Conditions 123

$\begin{array}{ll}\text { 5.7. Conclusions } & 124\end{array}$

$\begin{array}{ll}\text { REFERENCES } & 126\end{array}$

APPENDIX I. 


\section{LIST OF FIGURES}

Figure 1.1 Lithological map of the Slave Province $\quad 6$

Figure 1.2 Pan-Slave stratigraphic correlation $\quad 8$

Figure 1.3 Lithological map of Location A: Fault Zone 16

Figure 2.1 Simplified geological map of the Beniah Lake area 20

Figure 2.2 Composite stratigraphic section of the Beniah Formation 23

Figure 2.3 Outcrop sketch of quartz-pebble conglomerate sublithofacies 26

Figure 2.4 Outcrop sketch of quartz-arenite lithofacies 34

Figure 2.5 Detailed sketches of sedimentary structures in quartz-arenite lithofacies 35

$\begin{array}{lll}\text { Figure 2.6 Rose diagrams from paleocurrent data } & 39\end{array}$

Figure 2.7 Outcrop sketch of transition from SaSL to SiSL

Figure 2.8 Detailed stratigraphic columns of the siltstone-sandstone lithofacies 49

Figure 2.9 Stratigraphic column from Location D 53

Figure 2.10 Regional map of Location B

Figure 2.11 Composite stratigraphic column from Location B-2 57

Figure 2.12 Outcrop map of Location B-1 60

$\begin{array}{lll}\text { Figure 2.13 Point-counting results and QFL ternary diagram } & 68\end{array}$

Figure 3.1 General stratigraphy of the Bell Lake Group/Formation 70

Figure $3.2 \quad$ Lithological map of the Bell Lake area 72

Figure 3.3 Composite stratigraphic section of the Bell Lake Formation 73

Figure 3.4 Stratigraphic correlation of the Bell Lake Formation 86

Figure 3.5 Unconformable contact between the basement and Bell Lake Formation 88

Figure 3.6 Ternary diagrams for the Bell Lake sedimentary and igneous rocks 94

Figure 4.1 Abrupt and erosive transition from the WPSL to SaSL 96

Figure 4.2 Detailed stratigraphic columns of the WPSL, SaSL and QAL 97

Figure 4.3 Stratigraphic section illustrating three coarsening-upward successions 100

Figure 4.4 Two coarsening-upward successions from Location C-2 101

Figure 4.5 Coarsening-upward successions from Locations A, C-3 and D 102

$\begin{array}{lll}\text { Figure 4.6 Profile of a shelf-type shallow marine setting } & 106\end{array}$

Figure 5.1 Distribution of basement and cover rocks in the Slave Province 113

Figure 5.2 Tectonic scenario for the formation of the $\sim 2.8$ Ga sedimentary basins 114

Figure 5.3 Paleogeographic reconstruction of the Beniah Formation 116

$\begin{array}{lll}\text { Figure 5.4 Late stage basin development with contemporaneous volcanism } & 118\end{array}$ 
Figure 5.5 Paleogeographic reconstruction of the Bell Lake Formation

Figure 5.6 World-wide stratigraphic correlation of Archean quartz-arenite successions 
LIST OF PLATES

Plate 1.1.
A Tabular sets of quartz-arenite
B Fine-to medium-grained gabbro/sill
C Polymictic conglomerate (Beaulieu Rapids equivalent?)
D Various sedimentary and mafic clasts in polymictic conglomerate

Plate 2.1......
A Close-up of mudstone drape in quartz-pebble conglomerate
B Massive to stratified and cross bedded quartz-pebble conglomerate

C Close-up of well-rounded quartz clasts

Plate 2.2
A Close-up of matrix-supported breccia with angular fragments
B Angular clasts of sedimentary and possible volcanic origin
C Diffuse bedding planes in sedimentary breccia sublithofacies

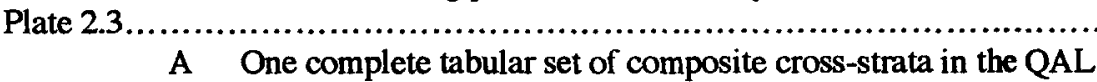

B Planar cross-bedding with cm-thick mudstone drape at the base

C Possible channel scour and medium- to small-scale cross-bedding

Plate 2.4
A Channel scours and tangential cross-bedding in the QAL
B Millimetre-thick mudstone drape between quartz-arenite beds
C Seven distinct tabular sets of composite cross-strata in QAL

Plate 2.5........
A Salient features of the sandstone-siltstone lithofacies
B Planar bedding and tangential cross-bedding in the SaSL
C Small-scale ripple marks with thin mudstone laminae
D Close-up of sandstone and thin siltstone interbeds

Plate 2.6.
A Wavy- to planar-bedded sublithofacies
B Alternating bands of sandstone and siltstone layers in WPSL
C Close-up of graded bedding in siltstone
D Planar to wavy laminae and ripple marks in WPSL

Plate 2.7......

$$
\begin{aligned}
& \text { A Iron-formation sublithofacies } \\
& \text { B Close-up illustrating the alternating quartz and clay-rich layers } \\
& \text { C Salient features of the IFSL }
\end{aligned}
$$

Plate 2.8
A Conformable contact between siltstone and pillowed flows
B Depositional contact between sedimentary and volcanic rocks
C Close-up of pillow with keel and chilled margin

Plate 2.9
A Thin-section of quartz-arenite under plane-polarized light
B Thin-section of siltstone with abundant mica and minor quartz
C Siltstone under cross-polarized light
D Iron-formation under cross-polarized light

Plate 3.1.
A Planar, parallel laminated, fuchsitic quartz-arenite
B Small-scale cross-bedding in thinly-bedded quartz-arenite
C Volcaniclastic sandstone with overlying iron-formation 


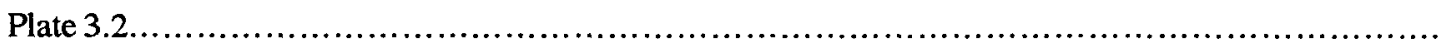

A Sharp contact between granitoid basement and overlying QAL

B Close-up of contact between basement and sedimentary rocks

C Onlapping structures of the QAL over the basement contact

Plate 3.3......

A Alternating bands of quartz-rich and clay-rich layers in the IFL

B Undulating parallel laminae in the IFL

C Transition between the SaSL and IFL intruded by a gabbro sill

Plate 3.4.......

A Cretaceous tidal rhythimites from the Horseshoe Canyon, Alberta

B Archean iron-formation from Bell Lake, NWT

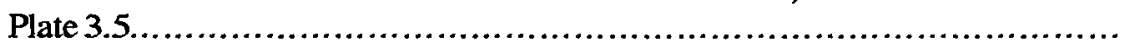

A Stained quartz-arenite sample indicating presence of K-feldspar

B Stained basement rocks with $\mathrm{K}$-feldspar

Plate 3.6........

A Thin-section of basement rock under plane-polarized light

B Basement rock under cross-polarized light

C Thin-section of quartz-arenite under cross-polarized light 


\section{LIST OF TABLES}

Table 2.1 Summary of the characteristics, processes and interpretation of the sedimentary lithofacies and corresponding sublithofacies in the Beniah Formation

Table 2.2 Point-counting results for the quartz-arenite and sandstonesiltstone lithofacies, Beniah Formation 


\section{CHAPTER 1}

\section{INTRODUCTION}

\subsection{Introduction}

Quartz-arenite deposits from the Proterozoic, Cambrian, Ordovician and Cretaceous have been well-documented (e.g. Suttner et al. 1981; Chandler 1988; Johnsson et al. 1988; Soegaard \& Eriksson 1989; Chakraborty \& Bose 1990), but Archean quartz-arenites are less well-known and their origin is poorly understood. Archean quartz-arenites have been documented from the Bababudan Group (3.2-3.0 Ga) of India (Srinivasan \& Ojakangas 1986) and the $3.0 \mathrm{Ga}$ Buhwa Greenstone Belt in South Africa (Fedo \& Eriksson 1996). In Canada, the Canadian Shield hosts quartz-arenite deposits in the Superior (Donaldson \& Ojakangas 19.77; Thurston \& Chivers 1990), the Hearne-Ray (Donaldson \& de Kemp 1998) and the Slave provinces (Covello et al. 1988). Studying Archean quartz-arenites is significant for understanding the Earth's early crustal evolution.

Younger quartz-arenite deposits commonly develop on the margins of emergent stable cratons, in shelf-type settings. Were there emergent cratons present in the Archean, ca. 2.8-2.9 billion years ago? Evidence from the. Beniah Lake area demonstrates that riftrelated tectonism might have taken place during basin development. Does this suggest that quartz-arenites form in tectonically active settings as well on stable cratons? All occurrences of quartz-arenites in the Slave Province overlie tonalite-gneissic basement. The average tonalite contains less than $20 \%$ quartz crystals. Could this basement have been the only source for all the framework quartz found in these deposits, or had there been recycling of pre-existing sedimentary deposits?

In order to address these problems many factors must be considered: 1) it is crucial to determine the depositional environment of the sedimentary rocks in question; 2) a facies 
analysis is required to reveal stratigraphic trends such as transgression, progradation and/or stratigraphic cyclicity and 3) a study of the tectonic implications will help to determine the origin of Archean quartz-arenites.

The Archean Beniah Formation is a 100-1000 m-thick succession of quartz-arenite and related siliciclastic rocks located in the Slave Province of the Northwest Territories. This formation provides an excellent opportunity to execute a detailed sedimentary facies analysis of Archean quartz-arenites. In addition, a sedimentary analysis of the 30-70 mthick Bell Lake Formation, another quartz-rich sedimentary sequence in the Slave Province, will be conducted for comparison.

The aim of this thesis is to document the physical sedimentology of the Beniah and Bell Lake formations using a sedimentary facies analysis, petrography and detailed bed-bybed mapping to determine the formational stratigraphy, which allows for the definition of the depositional setting and consideration of tectonic influence. Consequently, it will be possible to provide new information concerning the presence of Archean quartz-arenite successions, recount the history of the Beniah and Bell Lake formations in a coherent geodynamic context and discuss the presence or absence of an emergent stable craton in the Slave Province during the early Archean.

\subsection{Methodology}

The geological methods employed for this project include mapping, sampling, petrography and facies analyses. Two field seasons (1997-1998) were spent in the Northwest Territories to obtain the required data. The first season focused primarily on identifying prevalent outcrops and large-scale mapping (1:100 and 1:200) with less emphasis on detailed work, such as outcrop-scale sketches and stratigraphic columns. A vast selection of samples was collected and preliminary interpretations of the depositional setting were proposed. The majority of the data collected in the second field season included detailed, outcrop-scale mapping, revising the stratigraphic columns from the previous year and further sampling to ensure that all lithological units of the Beniah and Bell Lake formations were properly represented. Upon completion of the fieldwork, all 
diagrams and stratigraphic columns were scanned and digitized. This facilitated correlation and interpretation of the rocks. Distinct lithofacies were defined and characterized based on corresponding grain size, composition, modal abundance and contact relationships.

Facies mapping of the Beniah and Bell Lake formations was executed on both a large and small scale. Cartography of the region on a 1:100- and 1:200-scale allowed the identification of distinct rock-types and their contact relationships. In addition, detailed mapping (1:20- and 1:50-scale), including outcrop sketches and stratigraphic columns, helped define distinct lithofacies through the identification of assorted sedimentary structures, facies thickness and grain size. For all outcrops drawn, an orthogonal, 5-10 m spaced grid was established to ensure accuracy. A baseline oriented perpendicular to bedding was chosen and evenly spaced points were placed above and below the baseline until the entire mapable area was covered. The spacing interval between points depended on the detail sought and the size of the outcrop.

Structural and sedimentological measurements were integral components of the field mapping. Prominent sedimentary structures were used to determine stratification and younging direction of the sedimentary rocks. Consequently, the overall thickness of the formation and identification of any regional fold patterns could be established. Structural measurements provided evidence for the degree of deformation experienced by the rocks and the structural complexity of the study areas.

Extensive sampling of the sedimentary rocks provided representative examples of the corresponding lithofacies. Most samples were oriented, thus preserving their stratigraphic position and where possible, younging direction was indicated. The samples were cut for thin sections and used exclusively for petrographic analyses, which provided textural and compositional information of the quartz-arenites and related rocks on a microscopic scale. The majority of the sedimentary rocks sampled have been exposed to upper greenschist metamorphism, however, in many instances, primary textural features, such as grain-shape are preserved. Oriented samples also facilitated the identification of microscopic structural characteristics such as primary schistosity and crenulation cleavages. 
Regional and local stratigraphy of the sedimentary rocks was determined primarily using composite and detailed stratigraphic columns. These sections (3.5-165 m thick) illustrate the lateral and vertical continuity of the distinct lithostratigraphic units and along with the corresponding sedimentary structures, elucidate the depositional environment.

Petrography was used to support the characterization of these lithological units, in addition to the proper classification of the sedimentary rocks. In order to avoid shape bias in deformed samples, thin sections were cut both perpendicular and parallel to the primary schistosity or stretching lineation. As a result, both grain size and shape as well as bulk strain could be recorded.

The Gazzi-Dickinson (Dickinson \& Suczek 1979) point-counting method was used for statistical analyses of mineralogy. Four hundred points per thin section were counted in order to determine the modal percentage of each of the corresponding minerals. In addition, proper spacing intervals were chosen, depending on the overall grain size, to ensure that a representative sample population was counted. Once completed, the data was plotted on Quartz-Feldspar-Lithic Fragment (QFL) ternary diagrams (Folk 1980) to determine the precise classification of the sedimentary rocks. This method only includes framework grains and the matrix is therefore, not included in the classification.

Subordinate geotechnical methods, such as staining for potassium feldspars and paleocurrent analyses, were also applied to assist in supporting the overall aim of the thesis. Staining techniques (Bailey and Stevens 1960) required bathing of samples in both hydrofluoric acid and saturated sodium cobaltrinite. Potassium feldspars stained yellow, plagioclase grains turned beige and quartz stained grey. For paleocurrent analyses, only ripples and cross-laminae with exposed 3-D surfaces from a homoclinal section were measured. The resultant paleocurrent data was plotted on a stereonet, rotated to horizontal and plotted on rose diagrams for interpretation.

\subsection{Geological Setting}

\subsubsection{Regional Geology}


The Archean Slave Province $(510 \mathrm{~km} \mathrm{x} 710 \mathrm{~km})$, located in the Northwest Territories, Canada, contains: 1) felsic to mafic volcanic belts, 2.66-2.72 Ga (Isachsen \& Bowring 1997) with subordinate greenstone belts up to $3.3 \mathrm{Ga}$ (Hrabi et al. 1993; Hrabi \& Helmstaedt 1994); 2) sedimentary sequences including 2.8-3.0 Ga quartz-arenite deposits (Isachsen \& Bowring 1997), ca $2.67 \mathrm{Ga}$ turbiditic rocks (Henderson et al. 1987; Mortensen et al. 1992) and ca. 2.6 Ga. conglomeratic successions and 3) granitoid intrusions (Isachsen et al. 1991), all overlying a granitic-gneissic basement, 2.8-4.0 Ga (Isachsen \& Bowring 1997). Figure 1.1 is a lithological map of the Slave Province illustrating the spatial distribution of these rocks. The Slave Province is considered a distinct Archean Craton (Henderson 1981; Padgham \& Fyson 1992) and is characterized by: 1) more sedimentary rocks than volcanic rocks; 2) evidence of a sialic basement; 3) high felsic/mafic volcanic ratios and 4) abundant evolved K-rich granites. The Slave Province is host to the oldest known rocks in the world, the $3962 \pm 3$ Ma Acasta gneiss, dated by Bowring et al. (1989).

The Slave Province is characterized by crustal-scale, north-trending lineaments along which many of the volcanic belts, quartz-arenite sequences and most of the late-orogenic sedimentary rocks are restricted. Two of the most prominent fault zones include the ancestral Jackson Lake fault near Yellowknife and the Beniah Lake fault, located in the central Slave Province (Figure 1.1). Padgham \& Fyson (1992) suggested that the Beniah Lake fault represents a major tectonic break between an older, western terrane containing a sialic basement and a younger, eastern terrane. Turbidite assemblages (ca. 2.71-2.65 Ga) appear to cross the fault boundary, indicating that the fault is $2.8 \mathrm{Ga}$ or older.

A pan-Slave stratigraphic correlation has been developed, based on comprehensive mapping of the Yellowknife volcanic belt, defined by J. B. Henderson (1970). Mapping by the Geological Survey of Canada (Henderson 1970, 1975 and 1985; Lambert et al. 1992) and the Geology Division of Indian Affairs and Northern Development (Stubley \& Befin 1993; Jackson 1996; Stubley 1997), as well as radiometric age dating (Helmstaedt \& Padgham 1986; Bowring et al. 1989; Isachsen et al.1991; van Breemen et al. 1992; Isachsen \& Bowring 1994) resulted in establishing three distinct groups in the Yellowknife. 


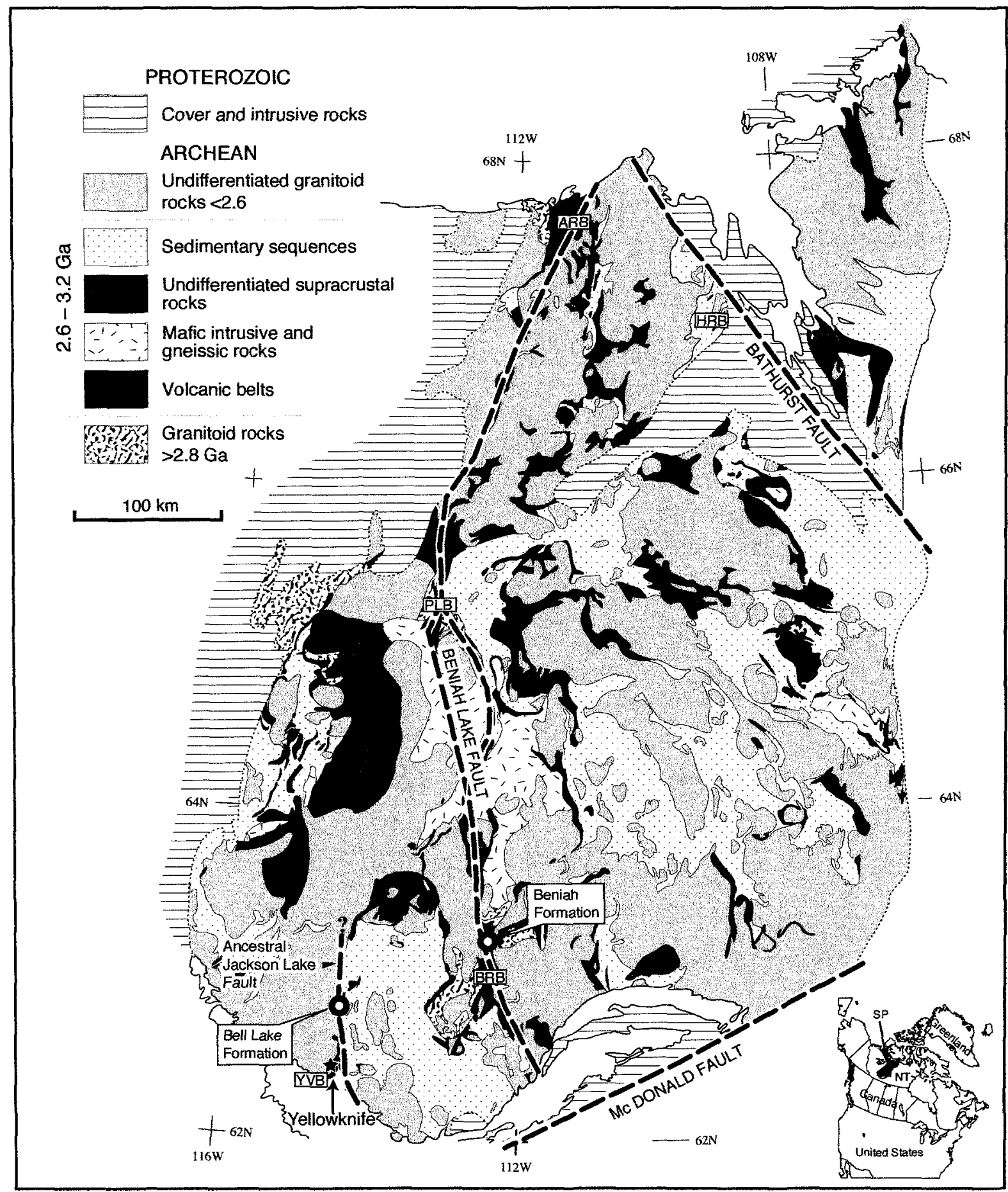

Figure 1.1. Lithological map of the Slave Province illustrating the location of the principal study areas, including the Beniah and Bell Lake Formations and various volcano-sedimentary successions mentioned in the text: BRB - Beaulieu River Volcanic Belt, YVB - Yellowknife Volcanic Belt, PLB - Point Lake Volcanic Belt, HRB - Hood River Volcanic Belt, and ARB - Anialik River Volcanic Belt. From Corcoran et al. 1998. 
volcanic belt with volcanic and sedimentary deposits spanning a period of 200 million years.

The Yellowknife volcanic belt (YVB), commonly referred to as the Yellowknife Supergroup, is divided into three principal groups including, the Kam, Banting and Duncan Lake groups (Figure 1.2). The YVB represents part of a continental supercycle, ca. 2722$2658 \mathrm{Ma}$ (Isachsen \& Bowring 1997), with the Kam Group corresponding to arc/back arc formation, the Banting and Duncan Lake groups representing arc unroofing and finally, arc/craton fragmentation represented by the overlying, younger Jackson Lake Formation (Mueller et al. 1998).

Underlying the YVB is the Bell Lake Group, which contains the oldest sedimentary sequence of the Slave Province overlying a granitoid basement. The Anton Complex contains well-foliated tonalite to granodiorite gneiss with $\mathrm{U}-\mathrm{Pb}$ ages in excess of $2.93 \mathrm{Ga}$ (Isachsen \& Bowring 1997). Directly overlying the basement is a series of clastic sedimentary rocks including fuchsite-bearing quartz-arenite and felsic volcaniclastic sandstone, as well as iron-formation and subordinate ultramafic rocks. These sedimentary sequences have been mapped in several locations throughout the Slave Province including: 1) the Dwyer and Bell Lake areas (Jackson 1996; Isachsen \& Bowring 1997); 2) Beniah Lake (Covello et al. 1988; Roscoe 1990; Roach \& Fyson 1992); 3) Beaulieu River (Rice et al. 1990); 4) Winter Lake (Hrabi et al. 1993) and the 5) Patterson and Brown Lake areas (Bleeker et al. 1999). The stratigraphy of this older sedimentary sequence is the focus of this study, with emphasis on Beniah and Bell lakes.

\subsubsection{Yellowknife Volcanic Belt Stratigraphy}

Figure 1.2 illustrates a detailed stratigraphic section through the Yellowknife Volcanic Belt (YVB), recently revised by Corcoran et al. (1999), along with lateral correlation throughout the Slave Province. The basement complex and pre-YVB-equivalent sedimentary successions (i.e. granitic-gneissic complex, quartz-arenite and iron-formation) underlie the Cameron River, Beaulieu River and Point Lake volcanic belts as well as the Anialik River Volcanic Belt, each of which is correlative with the Kam Group. The 


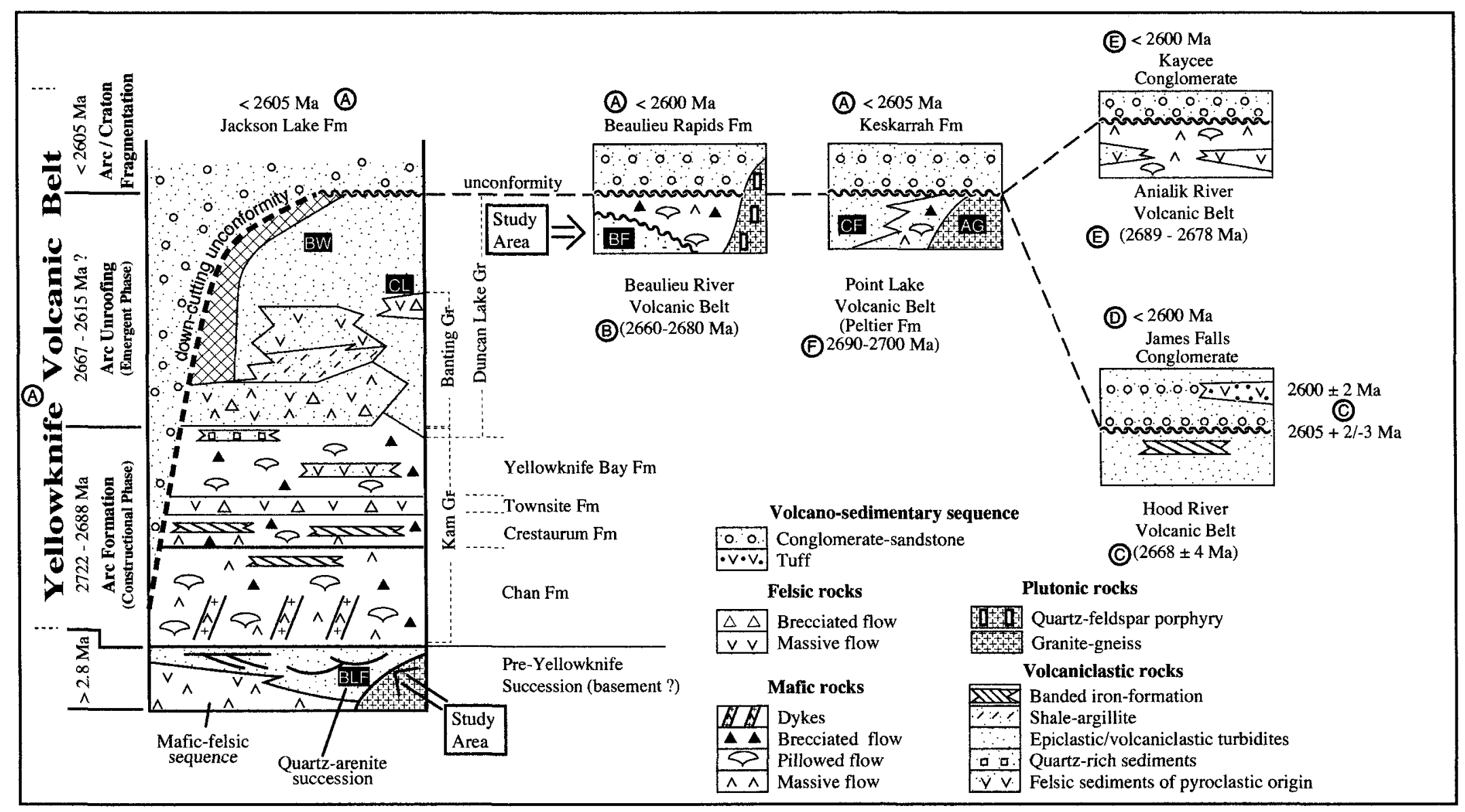

Figure 1.2. Stratigraphy of the Yellowkife Volcanic Belt, Slave Province and pan-Slave correlations (from Corcoran et al. 1998). BLF, Bell Lake Formation; BW, Burwash Formation; BF, Beniah Formation; CL, Clan Lake felsic volcanic complex; CF, Contwyto Formation; AG, Augustus Granite. References for age-dates: (A) Isachsen et al. (1991), Isachsen \& Bowring (1994); (B) Lambert et al. (1992); (C) van Breeman et al. (1992) (D) Villeneuve (1994); (E) Relf et al. (1994); (F) Northrup et al. (1997). 
Contoyto Formation in the Point Lake area contains epiclastic and volcaniclastic sedimentary rocks similar to Burwash Formation, while the Kaycee Conglomerate, Keskarrah Formation and Beaulieu Rapids Formation are all correlative with the $<2605 \mathrm{Ma}$ Jackson Lake Formation.

The 2722-2701 Ma (Isachsen \& Bowring 1994, 1997) Kam Group (10-12 km thick) is mainly composed of mafic volcanic flows and minor tuffaceous units, numerous dykes, sills and irregular gabbroic bodies. The Kam Group is subdivided into four formations including, from base to top, the Chan, Crestaurum, Townsite and Yellowknife Bay formations. The lowermost formations represent an ancient analogue of modern ocean-floor deposits with small felsic volcanic edifices, while the uppermost formations, with abundant volcaniclastic material, are related to the breaching of volcanic islands (Mueller et al. 1998).

The $\leq 6 \mathrm{~km}$-thick Chan Formation contains massive and pillowed flows, abundant gabbroic bodies and mafic dykes (Helmstaedt \& Padgham 1986). The Crestaurum Formation is made up of massive and pillowed mafic flows with numerous laterally continuous chert and felsic tuffs. Synvolcanic dykes are less abundant than in the Chan Formation, although post-volcanic mafic dykes are more numerous. Two lenticles of flows and gabbro sills with interbedded rhyodacite breccia, pillow dacite and locally welded units comprise the Townsite Formation. These units mark an important geochemical change from predominantly tholeiitic to calc-alkaline volcanism (Helmstaedt \& Padgham 1986). The lower part of the Yellowknife Bay Formation contains predominantly lenticular massive and pillowed flows and pillow breccia. Tuffaceous sedimentary rocks are present at various stratigraphic levels and coarse turbidite and quartz-rich sandstone are more abundant towards the top of the formation (Helmstaedt \& Padgham 1986).

The 2664-2658 Ma (Isachsen \& Bowring 1994) Banting Group is regionally unconformable with the Kam Group having both parallel and discordant bedding relationships at different localities. The Ingraham, Prosperous and Duck formations comprise the Banting Group. The Ingraham Formation contains sheared quartz monzonite with quartz-feldspar porphyry overlain by mafic flows, pillow breccia, felsic fragmental 
flows and bedded tuff with interlayered conglomerate. The Prosperous Formation consists of mainly massive to bedded felsic tuffs with interbedded mafic flows, tuffs, turbidites and subordinate conglomerate. Mafic to intermediate volcanic rocks are the main constituents of the Duck Formation. Volcanic facies include pillows, breccias and hyaloclastite with subordinate massive zones (Helmstaedt \& Padgham 1986).

The sedimentary-dominant Duncan Lake Group is divided into the Burwash and Walsh formations, both turbidite-dominated sequences. The Burwash Formation consists primarily of graywacke with interbedded slate that becomes more abundant near the top of the formation. The Walsh Formation differs from the Burwash only by its greater proportions of shale to siltstone and graywacke. The omnipresence of argillaceous material in the Walsh Formation has helped to preserve evidence of high levels of deformation and structural complexity.

The <2605 Ma (Isachsen et al. 1991) Jackson Lake Formation, composed of coarse clastic material, unconformably overlies both the Kam and Duncan Lake groups and is considered to be the youngest depositional event in the Slave Province. This formation contains alluvial sandstone and conglomerate that abruptly grade into a marine sequence (Mueller \& Donaldson 1994). The depositional model for the Jackson Lake Formation is a high-relief, fault- and unconformity-bounded basin with an embayment in close proximity to the open ocean and is interpreted to have formed during the terminal stage of Archean cratonization (Mueller et al. 2001)

\subsubsection{Local Geology}

The principal study area is located in the Beniah Lake region (lat. 63'19' $\mathrm{N}$, long. $\left.112^{\circ} 12^{\prime} \mathrm{E}\right)$, approximately $145 \mathrm{~km}$ northeast of Yellowknife, with additional information compiled from the Bell Lake area, approximately $45 \mathrm{~km}$ north of Yellowknife. The Beniah Lake area contains a variety of rocks including granitic-gneissic basement, ultramafic sills, siliciclastic sedimentary rocks, mafic volcanic with subordinate felsic to intermediate volcanic units, gabbro dykes, younger granitoid rocks with local quartz-feldspar porphyry and local polymictic conglomerates. The western extent of the Beniah Lake area is marked 
by the crustal-scale Beniah Lake fault. This major $\mathrm{N}$-trending fault zone is traceable for up to $600 \mathrm{~km}$ from the eastern reaches of Great Slave Lake to the northern margin of the Slave Province.

Appendix 1 includes a lithological map of the Beniah Lake area modified from data obtained by Roach in 1989-1990 (Roach 1990). This map also indicates the location of the four main study areas (A, B, C and D) that will be referred to throughout the text. This project focuses primarily on the sedimentary rocks of the Beniah Lake area, however descriptions of surrounding rock types are essential for understanding the geological history of the region. The metamorphic grade of the Beniah Lake rocks is predominantly upper greenschist to lower amphibolite facies. Locally, the presence of porphyroblastic hornblende and cordierite indicate higher metamorphic grade in rocks adjacent to pluton margins (Roach \& Fyson 1992). The prefix 'meta' is omitted to simplify rock descriptions.

Covello et al. (1988) first described the rocks at Beniah Lake and considered them part of the Beaulieu River volcanic belt, located $\sim 35 \mathrm{~km}$ to the south (see Fig. 1.1). The quartz-arenites and related rocks found at Beniah Lake were the first quartz-rich Archean clastic sedimentary rocks described from the Slave Province. Roscoe et al. (1989) considered the Beniah Lake sedimentary rocks and related ultramafic rocks to be a distinct lithology and named the sequence the Beniah Formation.

Highly deformed gneiss similar to the Anton and Sleepy Dragon complexes (Isachsen \& Bowring 1997; Bleeker \& Ketchum 1998) are basement to the Beniah Formation. The $3.11 \mathrm{Ga}$ (Isachsen \& Bowring 1997) basement contains massive granodiorite and cm-scale layers of strongly-foliated tonalite- and amphibolite-gneiss, commonly cut by mafic dykes. Ultramafic sills, including pyroxenites and dunites are situated stratigraphically between the top of the basement and the base of the sedimentary supracrustal assemblage. The chromite-bearing serpentinized dunites locally contain well-developed layered cumulate horizons. Detrital chromite found in the overlying sedimentary rocks may have been derived from the erosion of these Cr-rich dunites, indicating that the ultramafic rocks intruded the granitic-gneissic basement before or during deposition of the sedimentary rocks. 
The Beniah Formation contains a package of supracrustal rocks including siltstone, quartz-arenite, quartz-pebble conglomerate, iron-formation, felsic to intermediate volcaniclastic rocks and local mafic syn-tectonic rocks. The $\mathrm{Pb}-\mathrm{Pb}$ age of the siliciclastic rocks ranges from 3095-3395 $\mathrm{Ma}$, the former providing a maximum allowable depositional age (Isachsen \& Bowring 1997). Contacts between the basement and overlying rocks are lacking, however an unconformity is inferred. North-trending mafic dykes cross-cut the sedimentary rocks throughout the formation.

Extensive massive to pillowed and brecciated mafic flows overlie the sedimentary rocks of the Beniah Formation. Contacts are generally faulted and sheared, although in one location, the sedimentary succession is in conformable contact with overlying mafic volcaniclastic rocks and pillowed flows. In addition to the flows, numerous mafic dykes (fine- to coarse-grained) of thicknesses ranging from metres to tens of metres cut each of the above lithological units. In many instances, the dykes trend north to north-east, although due to the lack of exposed outcrops, it cannot be discerned whether or not all mafic dykes possess the same orientation, nor is it known if they originate from one or more geological events.

Two separate volcanic sequences are present in the Beniah Lake area, with one of Beniah Formation-equivalent age and the other related to a younger and entirely different event (possibly an extension of the ca. $2.7 \mathrm{Ga}$ Beaulieu River volcanic belt). Prior to this study, only one volcanic sequences had been described for the area, which was the younger Kam Group-equivalent volcanic rocks. The discovery of a new volcanic sequence is significant because the stratigraphy of the Beniah Lake area must be modified to include the older volcanic rocks.

Felsic to intermediate volcanic and volcaniclastic rocks are located in two distinct areas at Beniah Lake; one to the southeast and another in the central area (see Appendix 1). This lithological unit is predominantly composed of planar- and cross-laminated lapilli tuff with lesser lapilli-tuff breccia and tuff. The stratigraphic position of the volcaniclastic rocks is uncertain, although structural evidence, such as regional fold patterns, offer support that 
the felsic-intermediate rocks are younger than the Beniah Formation and stratigraphically overlie the $2.7 \mathrm{Ga}$ mafic pillowed flows.

A polymictic conglomerate is located in the northeastern part of Beniah Lake, within the Beniah Lake fault zone. The conglomerate, up to $15 \mathrm{~m}$ thick, is laterally exposed for 30 $\mathrm{m}$ and is bounded on either side by deformed quartz-arenite and medium- to coarse-grained mafic dykes/sills. Plate 1.1 A displays a photo of the deformed quartz-arenites. Primary sedimentary structures have been obliterated. An example of the mafic sill intruded by several small quartz veins is illustrated in Plate 1.1 B. The conglomerate contains a mix of angular to subangular, metre-sized boulders and cm-sized clasts of coarse-grained quartzarenite, siltstone, quartzofeldspathic material and deformed mafic dyke that lie within a matrix of finer quartz-rich material. Plates 1.1 C \& D show the variety of the angular to subangular clasts in the polymictic conglomerate.

This conglomerate is strikingly similar to those of the Beaulieu Rapids and Keskarrah formations, also located adjacent to the Beniah Lake Fault Zone. Both formations are ca. 2.6 Ga late-stage sedimentary basins influenced by movement along the Beniah Lake Fault (Corcoran et al. 1998, 1999). This outcrop could therefore mark a major unconformity between the $\geq 2.8 \mathrm{Ga}$ Beniah Formation and the ca. $2.6 \mathrm{Ga}$ Beaulieu Rapids Formation equivalent (Figure 1.3).

\subsection{Characteristics and Origin of Quartz-Arenites}

Quartz is generally the predominant mineral constituent of all sandstones, however quartz-arenites are particular in terms of their mineralogical and textural characteristics, as well as the depositional environments in which they form. They are, in fact, the most evolved and most mature of all sandstones. The definition of a quartz-arenite based on mineralogy varies slightly from one author to the next. Williams et al. (1982) defined a quartz-arenite as a sandstone with $>90 \%$ quartz (the definition utilized in this study). This was modified from and earlier classification of $>80 \%$ quartz (Williams et al. 1954). The definition of a quartz-arenite according to Pettijohn et al. (1987) is a sedimentary rock containing $95 \%$ or more detrital grains of quartz. Of the remaining $5 \%$, the mineralogy may 
Plate 1.1 (A) Tabular sets of quartz-arenite from the Beniah Formation. Generally, sedimentary structures have been obliterated due to the proximity of the rocks to the crustal-scale Beniah Lake Fault, although an east-younging direction, as indicated by the arrow (lower left corner), is inferred. Pen is 15 cm long.

Plate 1.1 (B) Fine- to medium-grained gabbro dyke/sill subsequently cut by thin quartz veinlets. Pen is $15 \mathrm{~cm}$ long.

Plate 1.1 (C) Polymictic conglomerate (Beaulieu Rapids equivalent?) containing both quartz-arenite and mafic dyke fragments (outlined). The arrow (upper right) indicates younging direction with pen for scale. For subsequent plates, the arrow indicating younging direction will be located in the upper right corner unless otherwise stated.

Plate 1.1 (D) Polymictic conglomerate with angular sedimentary and mafic clasts interpreted to represent a talus-scree breccia. Pen for scale and younging direction indicated by the arrow. 

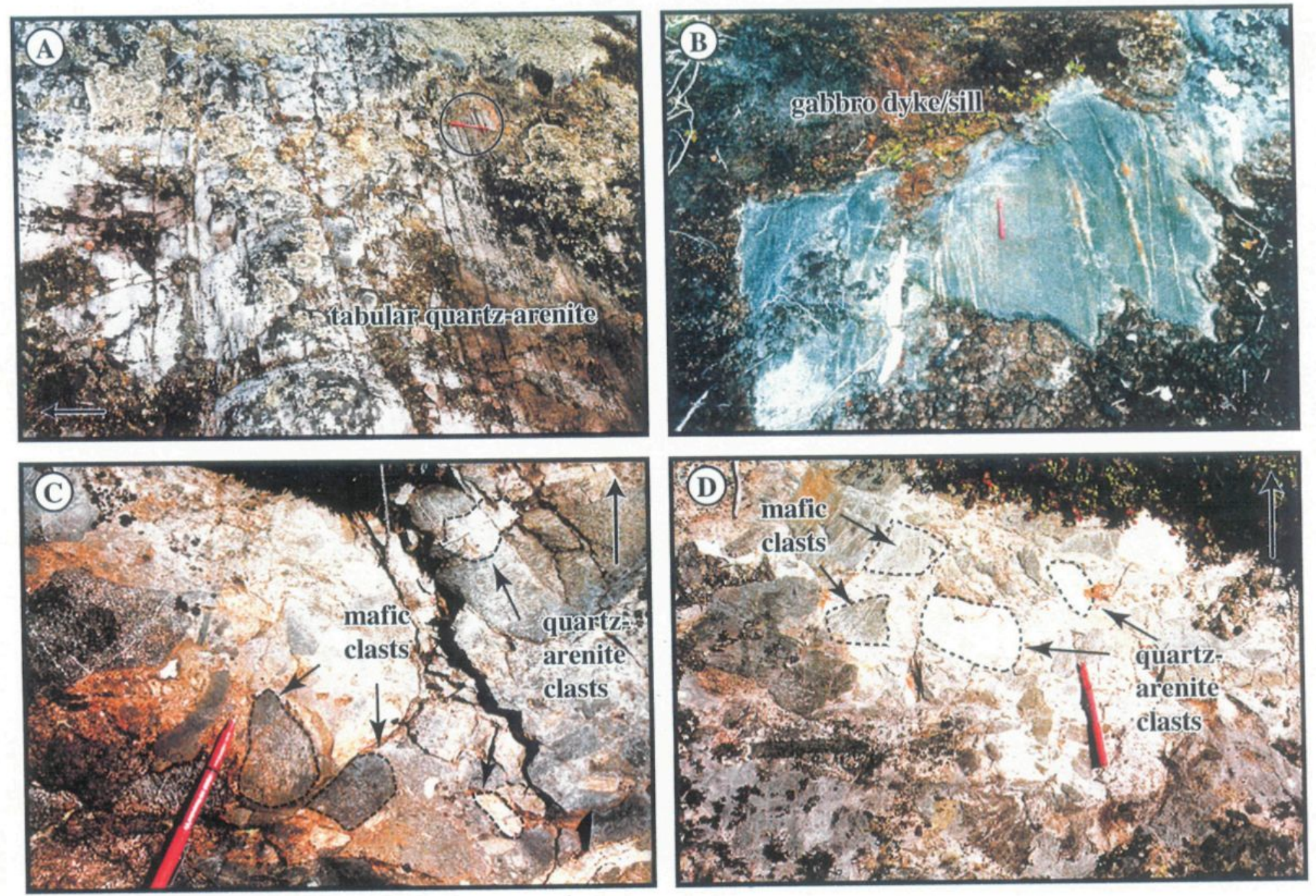

Plate 1.1 


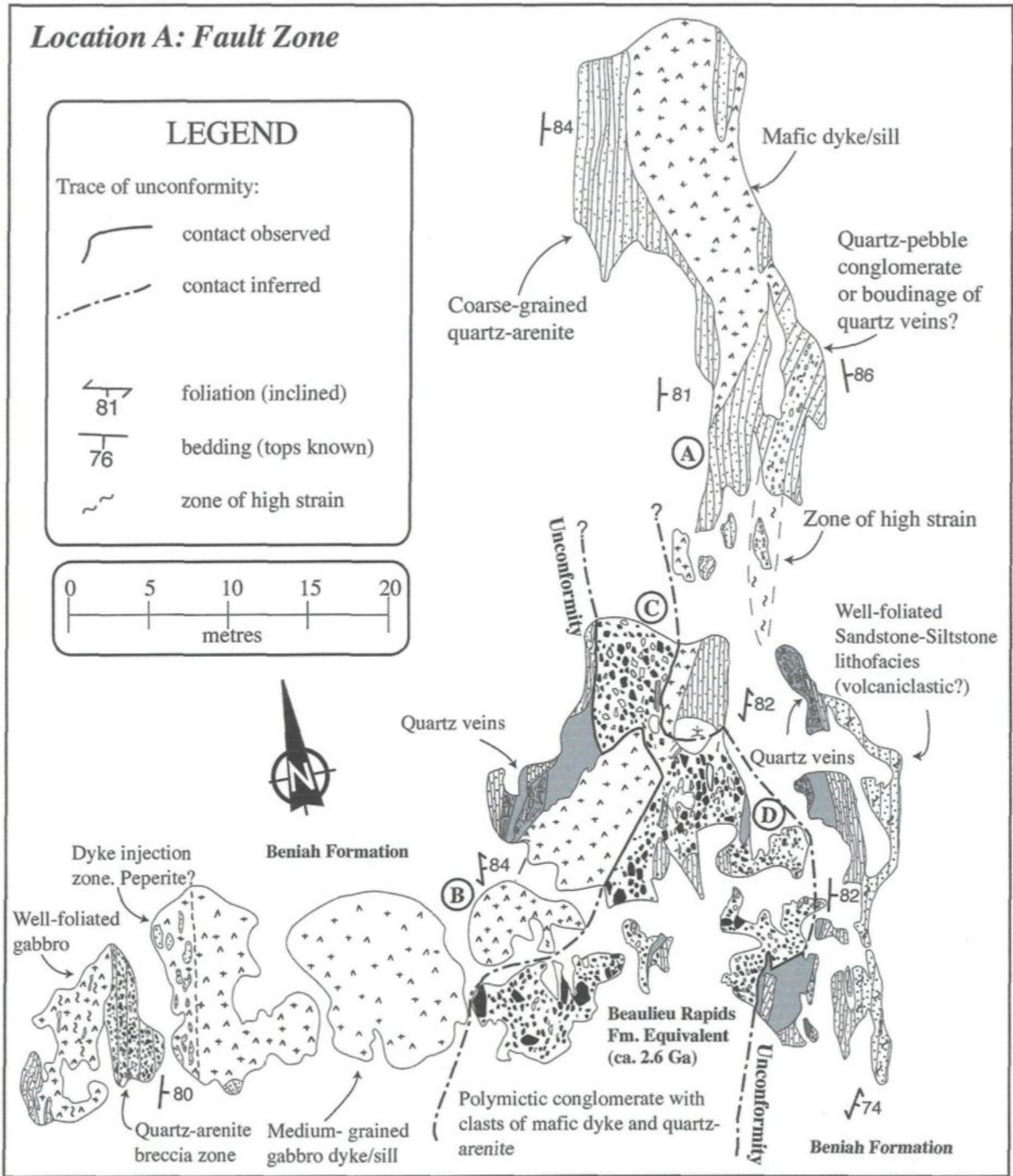

Figure 1.3. Local lithological map of location A with a major unconformity between the ca $2.8-2.9 \mathrm{Ga}$ Beniah Formation (quartz-arenite) and the ca $2.6 \mathrm{Ga}$ Beaulieu Rapids Formation equivalent (polymictic conglomerate). The mafic dykes/sills post-date the quartz-arenite and pre-date the conglomerate. The encircled letters A, B, C and D indicate the location of the photos illustrated in Plate 1.1. 
include feldspars, lithic rock fragments, detrital micas and a generally restricted suite of heavy minerals including zircon, rutile and tourmaline. Silica, carbonate and Fe-oxide are standard cements found in quartz-arenites. Quartz overgrowths and pressure-solution are common, resulting in a mosaic of interlocking quartz grains whereby grain boundaries may or may not be visible (Blatt et al. 1980). However, other quartz-arenites contain apparent well-rounded and well-sorted quartz grains.

Nomenclature generates further complication in classifying these rocks. The term quartz-arenite may be substituted for other terms such as orthoquartzite. These terms should not be mistaken with quartzite, which is, by definition, a metamorphosed sandstone. The quartz-arenites of the Beniah and Bell Lake formations have undergone metamorphism and therefore satisfy the definition of a quartzite, although the latter term will not be utilized to maintain consistency and simplicity.

Tropical weathering of coarse-grained quartz-bearing rocks such as granitoids enhances the formation of quartz-arenites (Folk 1980). In addition, pre-existing quartz-rich sedimentary rocks may be subject to erosion, thus creating more concentrated quartz-rich sands. The recycling of sedimentary rocks in this matter is more widely accepted as the link to the origin of quartz-arenites rather than the supposition that they were produced in a single sedimentary cycle (Suttner et al. 1981; Pettijohn et al. 1987).

Depositional environments vary from fluvial to eolian as well as shallow marine and are distinguishable mainly through textural evidence and sedimentary structures that are unique to each setting (Chandler 1988). Fluvial quartz-arenites commonly contain subangular to angular quartz grains, are poorly sorted, contain immature heavy mineral suites, as well as a kaolinitic matrix (Chandler 1988). Quartz-arenites derived from a fluvial setting occur in tropical climates with shield-like terranes whereby transport from the source is relatively short and a high residence time in the soil results in the chemical removal of less stable minerals such as feldspars and lithic fragments (Chandler 1988). Eolian quartz-arenites generally contain well-rounded quartz grains resulting from abrasion. These grains may also be pitted or frosted from interaction with other grains (Pettijohn et 
al. 1987). Sedimentary structures, such as large-scale cross-bedding, up to tens of metres thick, assist in identifying eolian quartz-arenites (Chandler 1988).

Shallow marine quartz-arenites are the most texturally mature, resulting from an extensive cumulative duration of transport (Suttner et al. 1981). The rising and falling of tides and/or wave action cause the grains to be in constant contact with one another, resulting in rounded to well-rounded, well-sorted sands (Chandler 1988). This depositional environment can also be readily identified through the presence of sedimentary structures such as low-angle tabular, tangential and herring-bone cross-bedding, mud drapes deposited on foresets of cross-laminae, channel scours, reactivation surfaces and tidal bundles (Nio \& Yang 1991). Fossil preservation in quartz-arenites, though uncommon, provides excellent evidence in support of shallow marine depositional environments, but must be restricted to the study of younger deposits.

Quartz-arenites are generally formed in tectonically stable settings, such as within a craton interior (fluvial) or on the continental shelf of passive margins comparable to the east coast of the Atlantic Ocean (Johnsson et al. 1988; Soegaard \& Eriksson 1989). In contrast, Chandler (1988) explains that quartz-arenites and quartz-wackes may be deposited both at the base of trailing edge continental prisms and/or in volcanic arc-related sequences in deep-sea turbiditic settings. These sediments were probably transported into such environments from marine shelves that subsequently became tectonically active. 


\section{CHAPTER 2}

\section{LITHOFACIES DISTINCTION}

\subsection{Introduction}

The sedimentary rocks of the Beniah Formation are divided into lithofacies defined by a combination of distinct mineralogy, grain size, textural characteristics and sedimentary structures. These lithofacies will be defined and characterized along with an interpretation of the processes involved in forming the corresponding structures. In addition, the petrography of each lithofacies will be described. All lithofacies represent a distinct sedimentary (volumetric) sub-environment within the Beniah Formation, which together correspond to a specific depositional setting that in turn delineates a geodynamic context.

The Beniah Formation contains four distinct sedimentary lithofacies including the 1) conglomerate, 2) quartz-arenite, 3) sandstone-siltstone and 4) siltstone-sandstone lithofacies. The conglomerate lithofacies is further divided into the quartz-pebble conglomerate and sedimentary breccia sublithofacies. In addition, the siltstone-sandstone lithofacies contains two sublithofacies, which include the wavy- to planar-bedded siltstone and the iron-formation sublithofacies. The locations of all distinct lithofacies are shown on a simplified lithological map of the Beniah Lake area (Figure 2.1). This map reveals four study areas (A, B, C \& D) where detailed mapping was implemented. Reference will be made to these locations throughout the text. The reader should refer to Appendix 1 for further detail.

Each sedimentary lithofacies is defined by the dominant grain size as well corresponding sedimentary structures. Mineralogical and textural maturity will also be examined, however these factors are limited by the degree of metamorphism and presence 


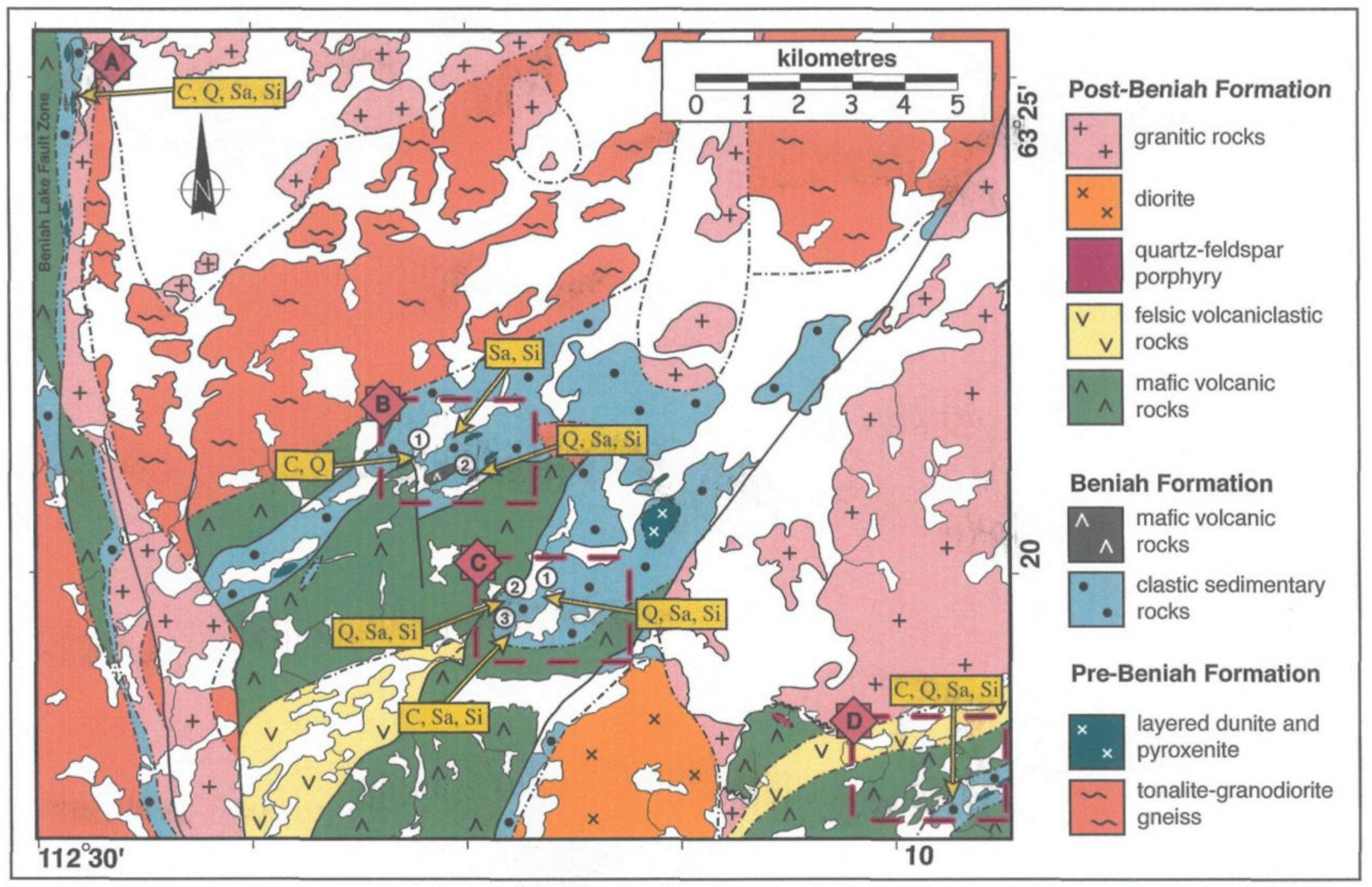

Figure 2.1. Simplified geological map of Beniah Lake (modified from Roach 1990) and location of study areas A, B, C and D. The encircled numbers 1, 2 and 3 indicate the location of specific outcrop areas discussed in the text. Also indicated are the distinct lithofacies found in each outcrop area: Conglomerate (C), Quartz-arenite (Q), Sandstone-Siltstone (Sa), Siltstone-Sandstone (Si). 
or absence of primary sedimentary features. Table 2.1 provides a summary of these sedimentary lithofacies including their characteristic structures, the processes controlling the structures and an interpretation of the consequent processes. A composite stratigraphic section, illustrated in Figure 2.2, represents the general stratigraphy of the Beniah Formation. A volcanic lithofacies that might be related to the Beniah Formation, including a sequence of mafic pillowed flows, will also be described.

\subsection{Sedimentary Lithofacies}

\subsubsection{Conglomerate Lithofacies}

The conglomerate lithofacies (CL) comprises $~ 5 \%$ of the Beniah Formation and is exposed in all four study areas (Fig. 2.1). The CL ranges in thickness from 3 to 13 metres with clast size ranging from $1-5 \mathrm{~cm}$ pebbles, $6-10 \mathrm{~cm}$ cobbles and local boulders $(>25 \mathrm{~cm})$. The $\mathrm{CL}$ is divided into a quartz-pebble conglomerate sublithofacies and a sedimentary breccia sublithofacies based on clast composition and shape.

The quartz-pebble conglomerate sublithofacies (QPSL), up to $13 \mathrm{~m}$ thick, is predominantly composed of pebble- to cobble-size quartz clasts, varying from $2-10 \mathrm{~cm}$ and constitutes $85 \%$ of the CL. Conglomerate beds (0.15-2.2 $\mathrm{m}$ thick) are massive to stratified and are locally capped with thin $(<1 \mathrm{~cm})$ mudstone drapes (Plate $2.1 \mathrm{~A})$. Conglomerate beds are clast-supported and moderately- to well-sorted. Cross-bedded, very coarse-grained to granular sandstones are locally interstratified with the conglomerate and range in thickness from 10 to $35 \mathrm{~cm}$ (Plate $2.1 \mathrm{~B}$ ). Foresets are locally capped by mudstone. Rip-up clasts from the mudstone drapes are found in the overlying conglomerate bed. Quartz clasts . are subrounded to well-rounded (Plate $2.1 \mathrm{C}$ ) with very low sphericity, exaggerated by a well-defined subvertical tectonic stretching lineation.

The overall geometry of the beds in the QPSL is tabular and individual beds are laterally traceable for several metres (limited by outcrop exposure). The QPSL both overlies and interstratifies the quartz-arenite lithofacies. In study area C-3, the QPSL is overlain by thin parallel laminated siltstone beds of the siltstone-sandstone lithofacies. Figure 2.3 depicts the QPSL and its corresponding characteristics including massive tabular 


\begin{tabular}{|c|c|c|c|}
\hline Lithofacies & Characteristics and Bedding Features & Processes & Interpretation/Architectural Elements \\
\hline $\begin{array}{l}\text { Conglomerate ( } 3 \text { to } 13 \mathrm{~m}) \\
\text { Quartz-pebble conglomerate } \\
\text { Overall thickness: } 1-13 \mathrm{~m} \\
\text { Bed thickness: } 0.15-2.2 \mathrm{~m}\end{array}$ & $\begin{array}{l}\text { Tabular geometry, massive, locally stratified, } \\
\text { minor mudstone drapes and rip-up clasts, } \\
\text { interbedded cross-stratified sandstone }\end{array}$ & $\begin{array}{l}\text { bedload transport } \\
\text { low to high flow regime } \\
\text { minor suspension deposition }\end{array}$ & $\begin{array}{l}\text { Gravel bars with migrating sandwaves. Shallow } \\
\text { marine, proximal to shoreline; tidally-influenced, } \\
\text { rapidly fluctuating flow-energy conditions }\end{array}$ \\
\hline $\begin{array}{l}\text { Sedimentary breccia } \\
\text { Overall thickness } 3-8 \mathrm{~m} \\
\text { Bed thickness: } 0.2-3 \mathrm{~m}\end{array}$ & $\begin{array}{l}\text { Massive, matrix-supported, diffused bedding, } \\
\text { angular sedimentary clasts }\end{array}$ & $\begin{array}{l}\text { limited transport of clasts, } \\
\text { catastrophic }\end{array}$ & Cohesive debris flow \\
\hline $\begin{array}{l}\text { Quart-arenite }(10-120 \mathrm{~m}) \\
\text { Tabular sets: } 0.25-1 \mathrm{~m} \\
\text { Individual beds: } 5-40 \mathrm{~cm}\end{array}$ & $\begin{array}{l}\text { Tabular sets, medium- to large-scale composite } \\
\text { cross-strata, tangential and planar cross-beds, } \\
\text { channel scours, reactivation surfaces, } \\
\text { superimposed ripples on larger cross-beds, } \\
\text { local mudstone drapes and planar bedding, } \\
\text { bimodal/bipolar paleocurrent pattern }\end{array}$ & $\begin{array}{l}\text { high sediment transport rates } \\
\text { scour filling, } \\
\text { settling of suspended load, low flow } \\
\text { regime }\end{array}$ & $\begin{array}{l}\text { Laterally migrating sandwaves, large dunes or } \\
\text { transverse bars. Tidally-influenced, high energy, } \\
\text { shallow water deposit; high sediment transport } \\
\text { rates, suspension deposition between tidal periods, } \\
\text { wave reworking }\end{array}$ \\
\hline $\begin{array}{l}\text { Sandstone-Siltstone }(10-16 \mathrm{~m}) \\
\text { Composite beds: } 0.25-1 \mathrm{~m} \\
\text { Individual beds: } 5-30 \mathrm{~cm}\end{array}$ & $\begin{array}{l}\text { Tabular geometry, tangential composite cross- } \\
\text { beds, planar to wavy beds, reactivation } \\
\text { surfaces, channel scours, ripple marks, } \\
\text { mudstone drapes, bimodal/bipolar paleocurrent } \\
\text { pattern }\end{array}$ & $\begin{array}{l}\text { low flow regime } \\
\text { scour filling } \\
\text { low-amplitude sandwaves and drape } \\
\text { deposition }\end{array}$ & $\begin{array}{l}\text { In channel migrating sandwaves. Wave- and tide- } \\
\text { induced, shallow marine, subtidal setting; possible } \\
\text { storm influence, highly fluctuating wave-energy } \\
\text { conditions }\end{array}$ \\
\hline $\begin{array}{l}\text { Siltstone-Sandstone }(2-28 \mathrm{~m}) \\
\text { Wavy- to planar bedded } \\
\text { Overall thickness } 5-13 \mathrm{~m} \\
\text { Bed thickness: } 0.1-3 \mathrm{~m}\end{array}$ & $\begin{array}{l}\text { Planar to wavy laminae, ripple marks, local } \\
\text { pebble lags, interbeds of medium- to coarse } \\
\text { grained, massive, planar bedded and cross- } \\
\text { bedded sandstone }\end{array}$ & $\begin{array}{l}\text { suspension deposition with lower } \\
\text { flow regime ripples } \\
\text { low flow regime planar bed flow } \\
\text { sandwave migration }\end{array}$ & $\begin{array}{l}\text { Channel levee. Low-energy environment, tide and } \\
\text { wave influenced; subordinate influxes of higher- } \\
\text { energy storm conditions }\end{array}$ \\
\hline $\begin{array}{l}\text { Iron-formation } \\
\text { Overall thickness } 2-28 \mathrm{~m} \\
\text { Bed thickness: } 1-20 \mathrm{~cm}\end{array}$ & Planar, parallel laminae, local wavy laminae & $\begin{array}{l}\text { predominantly suspended load } \\
\text { settling }\end{array}$ & $\begin{array}{l}\text { Subtidal pool, distal to shoreline, diagenetic } \\
\text { replacement }\end{array}$ \\
\hline
\end{tabular}

Table 2.1. Summary of the characteristics, processes and interpretations for the sedimentary lithofacies (in bold) and corresponding sublithofacies (in italics) of the Beniah Formation. 


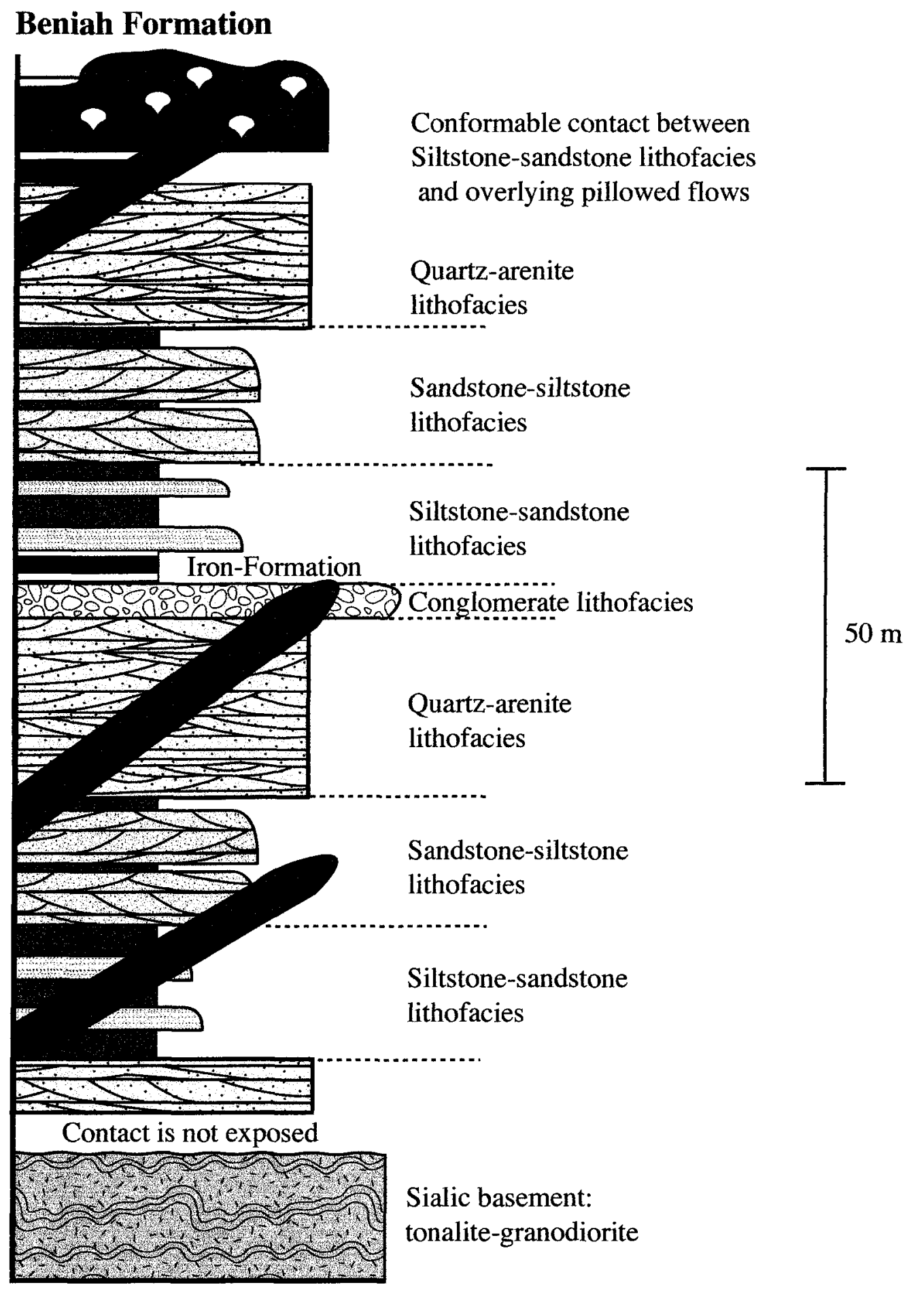

Figure 2.2. Composite section of the Beniah Formation including the basement rock, various sedimentary lithofacies, locally conformable mafic volcanic rocks and cross-cutting mafic dykes. 
Plate 2.1 (A) Close-up of mudstone drape separating two conglomerate beds, suggestive of fluctuating flow energy conditions during deposition. Pen $(15 \mathrm{~cm})$ indicates northward younging direction.

Plate 2.1 (B) Quartz-pebble conglomerate sublithofacies (QPSL) containing massive to stratified pebble beds and interstratified cross-bedded, very coarse-grained to granular sandstone. Locally, the beds are capped by $\mathrm{mm}$ - to $\mathrm{cm}$-thick mudstone drapes. Top is to the north as indicated by the arrow (lower right corner). Pen (circled) is $15 \mathrm{~cm}$.

Plate 2.1 (C) Close-up of quartz-pebble conglomerate illustrating the subrounded to well-rounded quartz clasts. Scale is $5 \mathrm{~cm}$ long and arrow indicates the younging direction. 

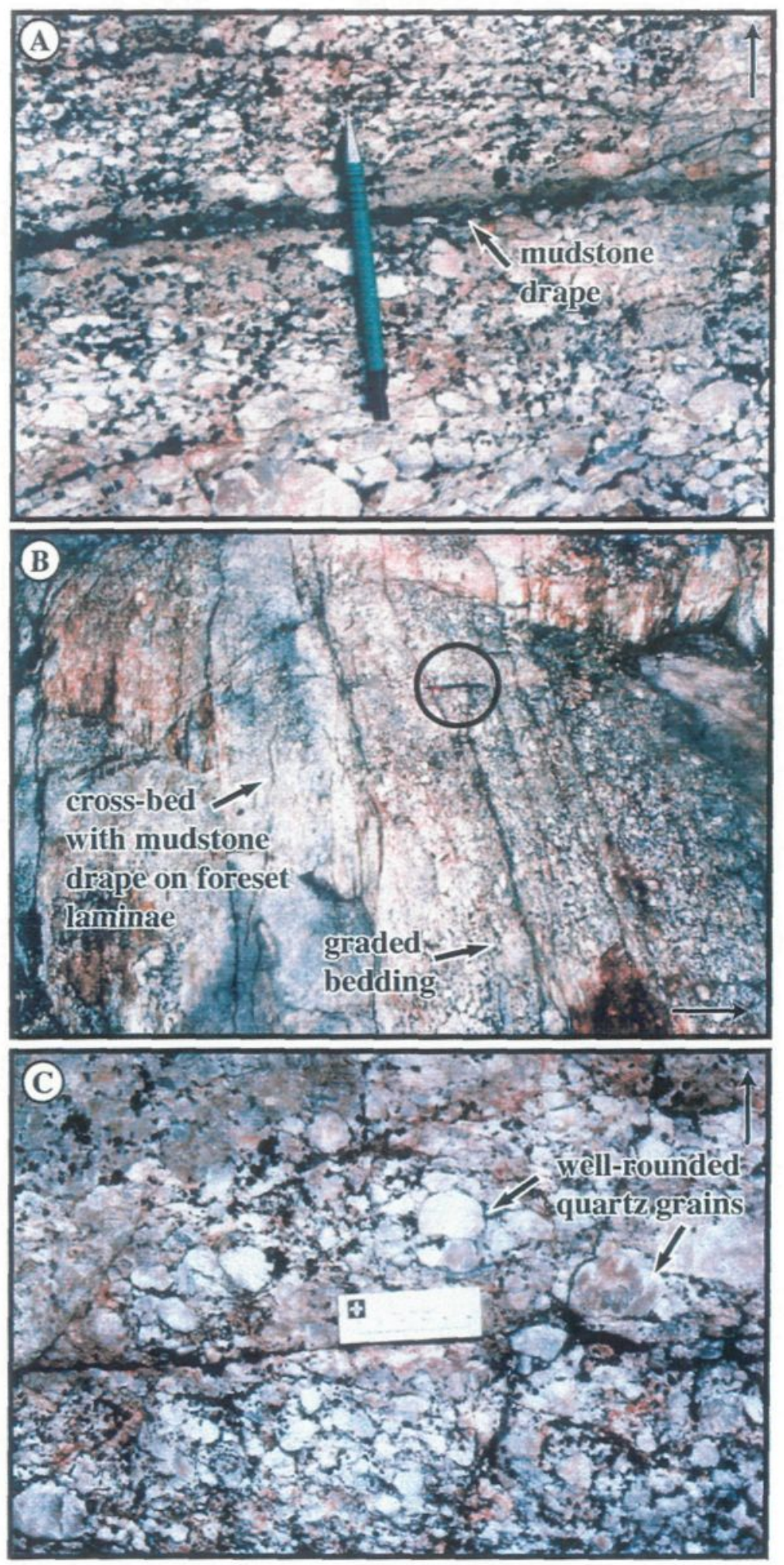

Plate 2.1 


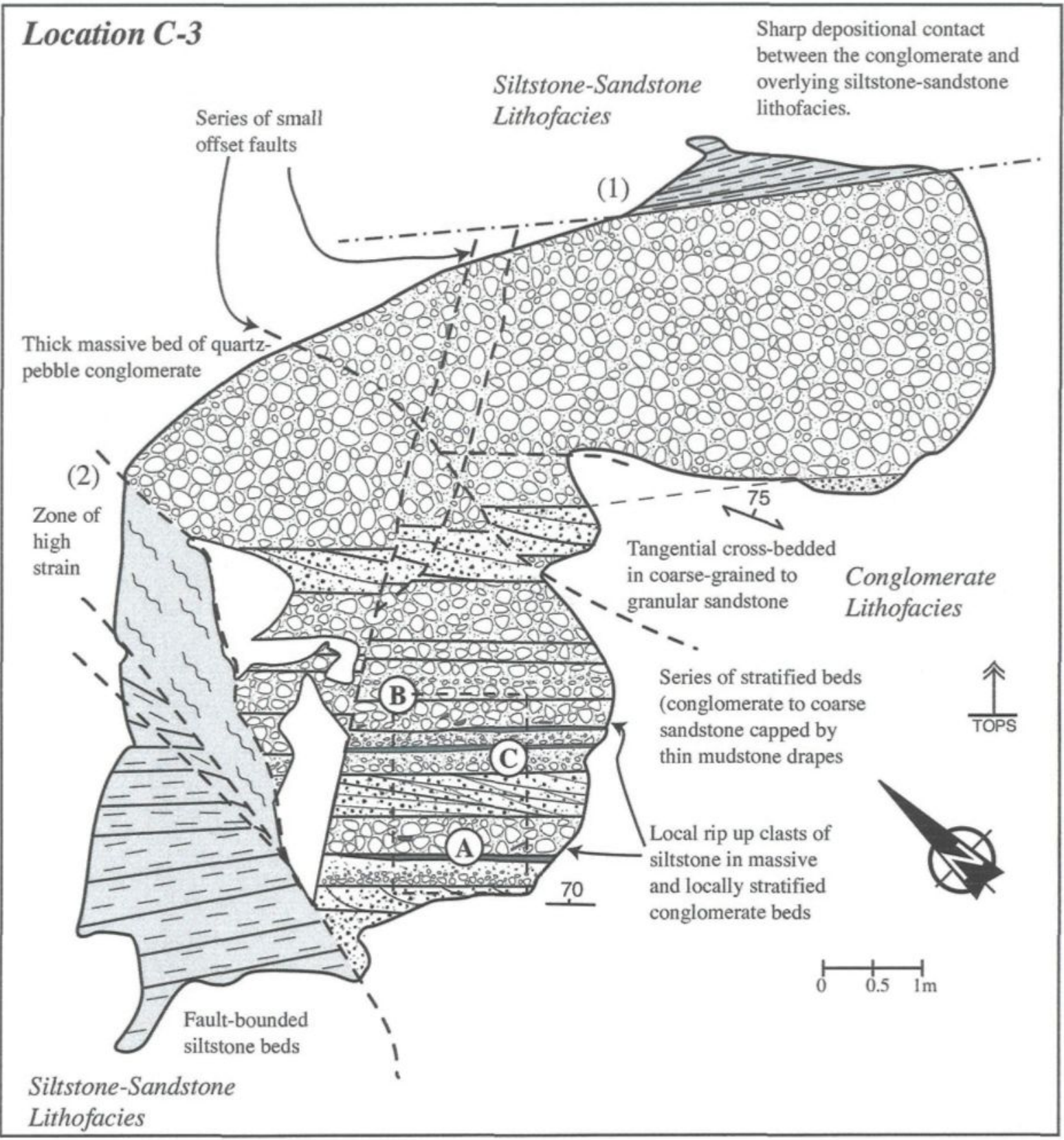

Figure 2.3. Sketch of the quartz-pebble conglomerate sublithofacies including massive and graded beds, very coarse-grained to granular sandstone interbeds containing cross-laminae, local rip-up clasts and clay drapes. Sharp contact between the conglomerate and overlying siltstone-sandstone lithofacies is observed near the top of the sketch (1). The contact between these units in area (2) is tectonic as indicated by the zones of high strain and off-setting faults. The encircled letters; A, $\mathrm{B}$ and $\mathrm{C}$ correspond to the photos in Plate 2.1. 
beds containing well-rounded quartz clasts, tangential cross-bedded, granular sandstone interbeds, rip up clasts and mudstone drapes. Also indicated is the sharp non-erosive contact between the QPSL and the overlying siltstone-sandstone lithofacies, which also straddles the QPSL on the western end of the outcrop. This contact is interpreted to be tectonic and evidence for faulting and high strain are obvious. The location of the photos from Plate 2.1 are indicated in Figure 2.3.

The sedimentary breccia sublithofacies (SBSL) comprises $\sim 15 \%$ of the $\mathrm{CL}$ and is represented by 3-8 $\mathrm{m}$ thick breccias composed primarily of angular sedimentary clasts (Plate $2.2 \mathrm{~A}, \mathrm{~B}$ ). Beds are massive and contacts within the sublithofacies are diffuse (Plate 2.2 C). No imbrication or stratification is present. The polymineralic breccia contains clasts ranging from $0.2-10 \mathrm{~cm}$ (granular to cobble) and is supported by a matrix of medium- to coarse-grained quartz-rich material. Framework clasts include coarse-grained quartzarenite, medium-grained sandstone and massive to laminated siltstone and iron-formation. Dark green, aphanitic fragments of possible volcanic origin are also present, though less abundant (see Plate 2.2 A). The SBSL, only encountered in study area D, is overlain by magnetite-rich iron-formation and coarse-grained quartz-rich sandstone.

\subsubsection{Interpretation}

Clast-supported conglomerates interstratified with cross-bedded sandstones comprising the QPSL are indicative of a high-energy environment with fluctuating flow velocities (Mueller \& Dimroth 1987; Reading \& Collinson 1996). A combination of wave and tidal influence is envisaged. Bedload was predominantly transported by traction currents, based on the overall grain size (Prothero \& Schwab 1996). Mudstone laminae intercalated with quartz-pebble conglomerate indicate rapidly fluctuating current energy conditions (Eriksson 1977) involving both bedload transport and suspension sedimentation. Mudstone drapes on foreset laminae and between beds reflect fluctuating energy conditions consistent with wave influence (Reading and Collinson 1996). Rip-up clasts indicate elevated erosive power and marked roundness of the clasts argues for significant clast interaction, abrasion and an overall high net movement of grains (Folk 1980). 
Plate 2.2 (A) Close-up of breccia with angular volcanic (?) and sedimentary fragments supported by a quartz-rich matrix. Pen is $14.5 \mathrm{~cm}$ long.

Plate 2.2 (B) Close-up of sedimentary breccia with angular clasts of various composition. Pen $(14.5 \mathrm{~cm})$ for scale.

Plate 2.2 (C) Sedimentary breccia sublithofacies containing angular fragments of predominantly sedimentary origin. The breccia is interpreted as a mass flow deposit. Bedding planes are diffuse. Pen is $14.5 \mathrm{~cm}$ and the arrow indicates tops to the south. 

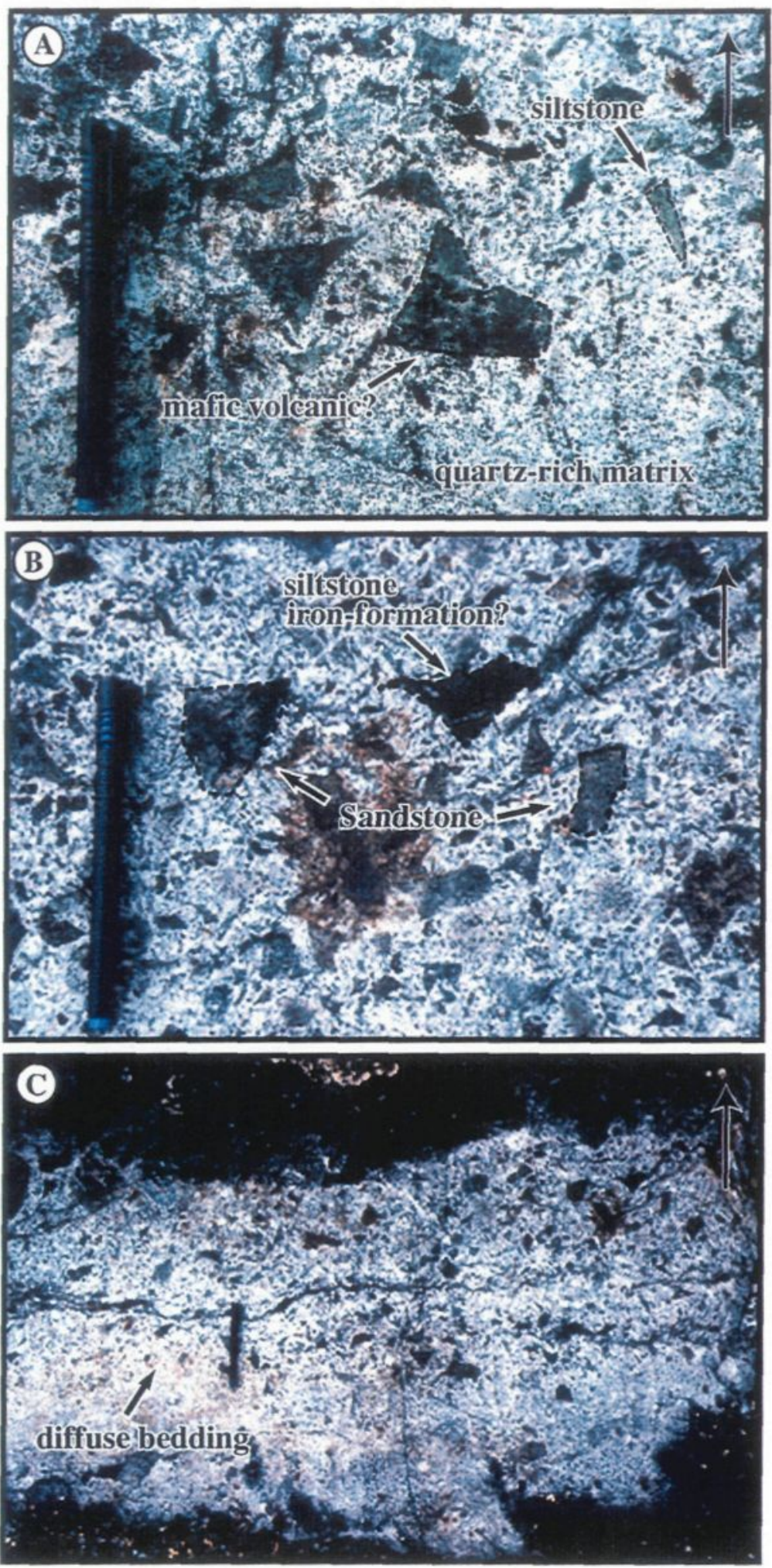

Plate 2.2 
Interfingering tabular conglomerates and cross-stratified sandstones with mudstone drapes indicate alternating fairweather and storm conditions and/or the influence of tides (Reading \& Collinson 1996). The presence of mudstone drapes interstratified with coarse-grained deposits indicates suspension sedimentation. The combination of suspension deposition with traction currents and bedload transport denotes highly fluctuating flow energy conditions consistent with tidally-influenced sedimentary deposits. The QPSL therefore represents a sublithofacies influenced mainly by wave and tidal processes with possible storm activity.

The massive, matrix-supported beds of the SBSL are correlative with mass-flow deposits resulting from isolated catastrophic events (Prothero \& Schwab 1996). The angularity and size of the fragments reveal that transport was limited. Cohesive intraformational debris flows described by Laird (1995) share similar characteristics to the poorly-stratified, matrix-supported breccias of the SBSL.

\subsubsection{Quartz-Arenite Lithofacies}

The quartz-arenite lithofacies (QAL) constitutes approximately $58 \%$ of the Beniah Formation. The QAL is generally buff white in appearance with local weathered red/pink patches and contains laminae of green mica (fuchsite?). This lithofacies is $10-120 \mathrm{~m}$ thick containing $0.25-1 \mathrm{~m}$-thick composite tabular beds. Individual bed thickness ranges from 10 to $35 \mathrm{~cm}$ and are laterally continuous over several metres.

The QAL contains a diverse series of sedimentary structures including: 1) planar bedding, 2) complex cross-bedding, including abundant low-angle tangential cross-beds and local planar cross-beds, 3) channel scours and 4) mudstone drapes. Planar beds are generally less than $10 \mathrm{~cm}$ thick and parallel laminae within beds are subtle. The ubiquitous tangential cross-beds include small- $(2$ to $10 \mathrm{~cm})$, medium- $(10-30 \mathrm{~cm})$ and large-scale (30 to $>50 \mathrm{~cm}$ ) beds that make up tabular sets $20-100 \mathrm{~cm}$ thick. Tabular sets containing multiple small- and medium-scale tangential cross-beds are referred to as composite crossbeds. Plate $2.3 \mathrm{~A}$ illustrates one composite bed bounded by planar, parallel bedding planes

with mm-thick mudstone drapes. Between the mudstone drapes is a series of complex 
Plate 2.3 (A) Close-up of cross-beds within a tabular set of the QAL. Orientation of cross-laminae is predominantly unidirectional. Foreset laminae indicate a south-younging direction, as shown by the $15 \mathrm{~cm}$ long pen. The tabular set is $\sim 35 \mathrm{~cm}$ thick with individual beds attaining thicknesses from $5-10 \mathrm{~cm}$.

Plate 2.3 (B) Planar cross-bedding in the QAL. Foreset laminae are at $\sim 32^{\circ}$ and give a younging direction to the south (arrow). The top of the underlying bed is marked by a cm-thick mudstone drape. The pen is $15 \mathrm{~cm}$ long.

Plate 2.3 (C) Possible channel scours within the QAL. Medium- and small-scale crossbeds are also visible and tops is to the south, as indicated by the $15 \mathrm{~cm}$ long pen. Current direction of channels is perpendicular to cross-strata. 

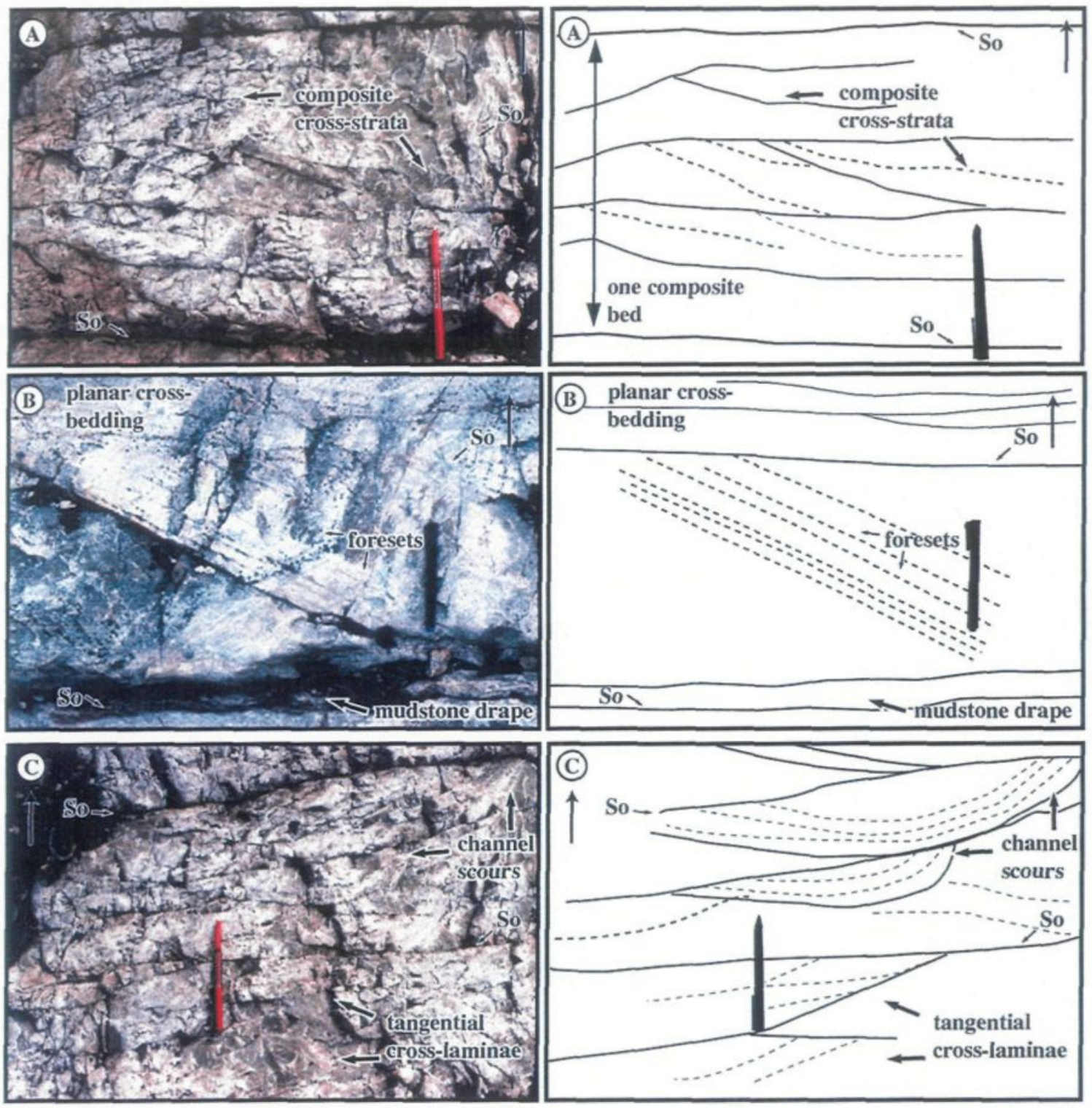

Plate 2.3 
small- and medium-scale cross-laminae. Low-angle composite cross-strata are bounded by parallel bedding planes indicating the overall tabular geometry of the QAL (Figure 2.4). Contacts between tabular beds are sharp. All plates and figures are illustrated with younging directions towards the top of the page unless otherwise stated.

Local planar cross-bedding is also found in the QAL. The 20-40 cm-thick beds contain a series of planar foresets $\sim 30^{\circ}$ to the bedding plane (Plate 2.3 B and Figure 2.5 A). Large-scale cross-beds locally display smaller sinuous ripples on foresets of these crossbeds (Figure 2.5 B). Foreset orientation trends both east and west to the south-younging quartz-arenites in location $\mathrm{C}-2$, whereas location $\mathrm{C}-1$ primarily contains unidirectional cross-beds. Possible channel scours in the QAL are $5-20 \mathrm{~cm}$ thick and appear to truncate the composite cross-strata (Plate 2:3 C \& $2.4 \mathrm{~A}$ ). Reactivation surfaces are common and tend to down-cut into pre-existing cross-strata. Erosion surfaces are readily identifiable in the field. Mudstone drapes, up to metres in length and $\mathrm{mm}$ to $\mathrm{cm}$ thick, occur on the summital and basal surfaces of tabular sets as well as on reactivation surfaces and foreset laminae (Plate $2.4 \mathrm{~B}$ ). The tabular geometry and composite bedforms of the QAL are illustrated in Plate 2.4 C.

The QAL is found in all study areas (A, B, C and D) (Figure 2.1) and contacts to the underlying sandstone-siltstone lithofacies are generally gradational over $1-2 \mathrm{~m}$. The transition from the sandstone-siltstone and quartz-arenite lithofacies is marked by a decrease in siltstone abundance and an overall increase in grain size up-section. Upper bounding surfaces with the siltstone-sandstone lithofacies are commonly sharp.

\subsubsection{Interpretation}

The tabular geometry and characteristic sedimentary structures of the QAL are indicative of shallow water deposits (Dalrymple 1992; Reading \& Collinson 1996; Johnson $\&$ Baldwin 1996). Large-scale tangential and planar cross-beds within the coarse- to very coarse-grained sandstones represent laterally migrating sandwaves (Reineck \& Singh 1980; Allen 1981; George 1994). The tangential cross-beds illustrated in Figures 2.4 and 2.5 A represent sinuous migrating bedforms, whereas the planar cross-beds shown in Plate $2.3 \mathrm{~B}$ 


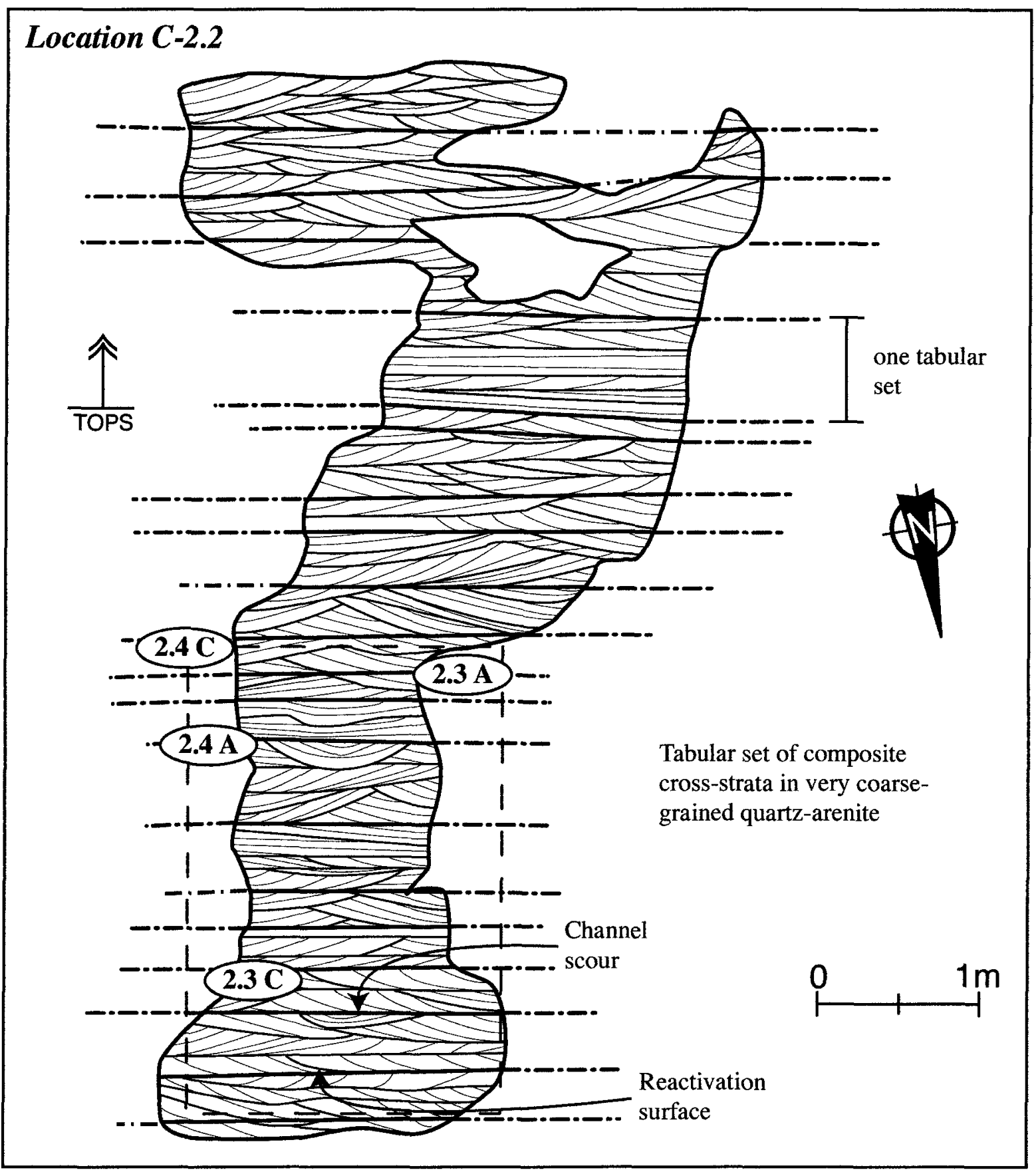

Figure 2.4. Detailed outcrop sketch illustrating the salient sedimentary structures of the quartz-arenite lithofacies including tangential composite cross-strata, reactivation surfaces and channel scours. The location of photos from Plates 2.3 and 2.4 are shown (Plate $2.4 \mathrm{C}$ is outlined). North arrow is inverted to accommodate younging direction. 


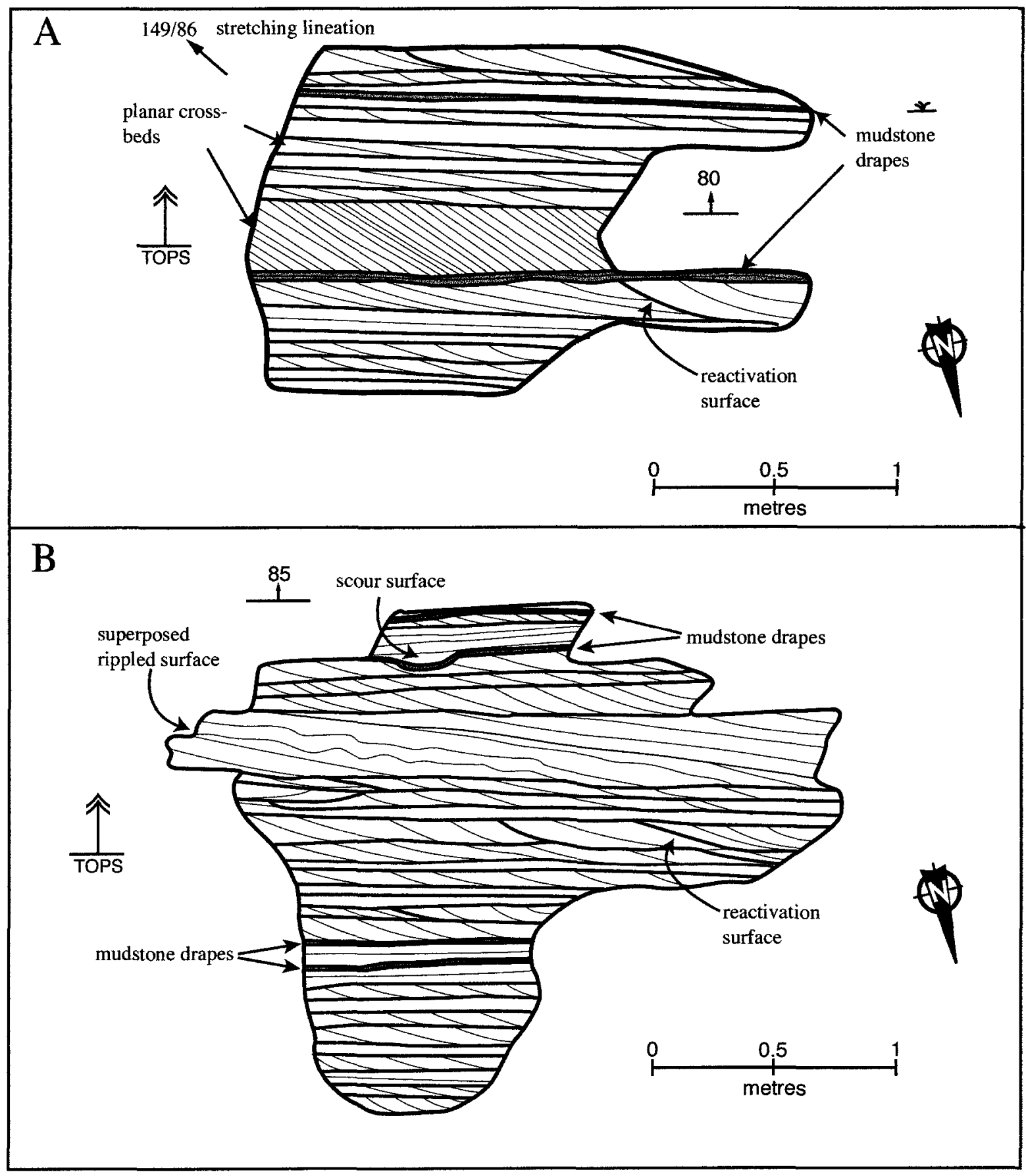

Figure 2.5. Sketches from Location C-1. A) Planar and tangential cross-bedding in the quartz-arenite lithofacies. Locally, thick $(<2 \mathrm{~cm})$ clay drapes are present between tabular sets. B) Quartz-arenite lithofacies illustrating large- and medium-scale cross-beds with locally rippled foresets and $\mathrm{mm}$ thick clay drapes between tabular sets. 
Plate 2.4 (A) Close-up revealing the complex sedimentary structures of the QAL including channel scours and tangential cross-beds. Orientation of foreset laminae indicates a bi-directional current. Pen for scale $(15 \mathrm{~cm})$ and arrow indicates the younging direction.

Plate 2.4 (B) Millimetre-thick mudstone drape between the bedding planes of two coarse-grained quartz-arenite beds. Also indicated is a $17 \mathrm{~cm}$ long, $8 \mathrm{~cm}$ deep scour surface. Pen is $15 \mathrm{~cm}$ long and younging direction is to the south (indicated by arrow).

Plate 2.4 (C) Tabular sets of quartz-arenite (from QAL) containing complex composite cross-strata. Seven distinct tabular sets have been outlined in the photo. Younging direction is to the south as indicated by the arrow (bottom left corner) and the pen is $15 \mathrm{~cm}$ long. 

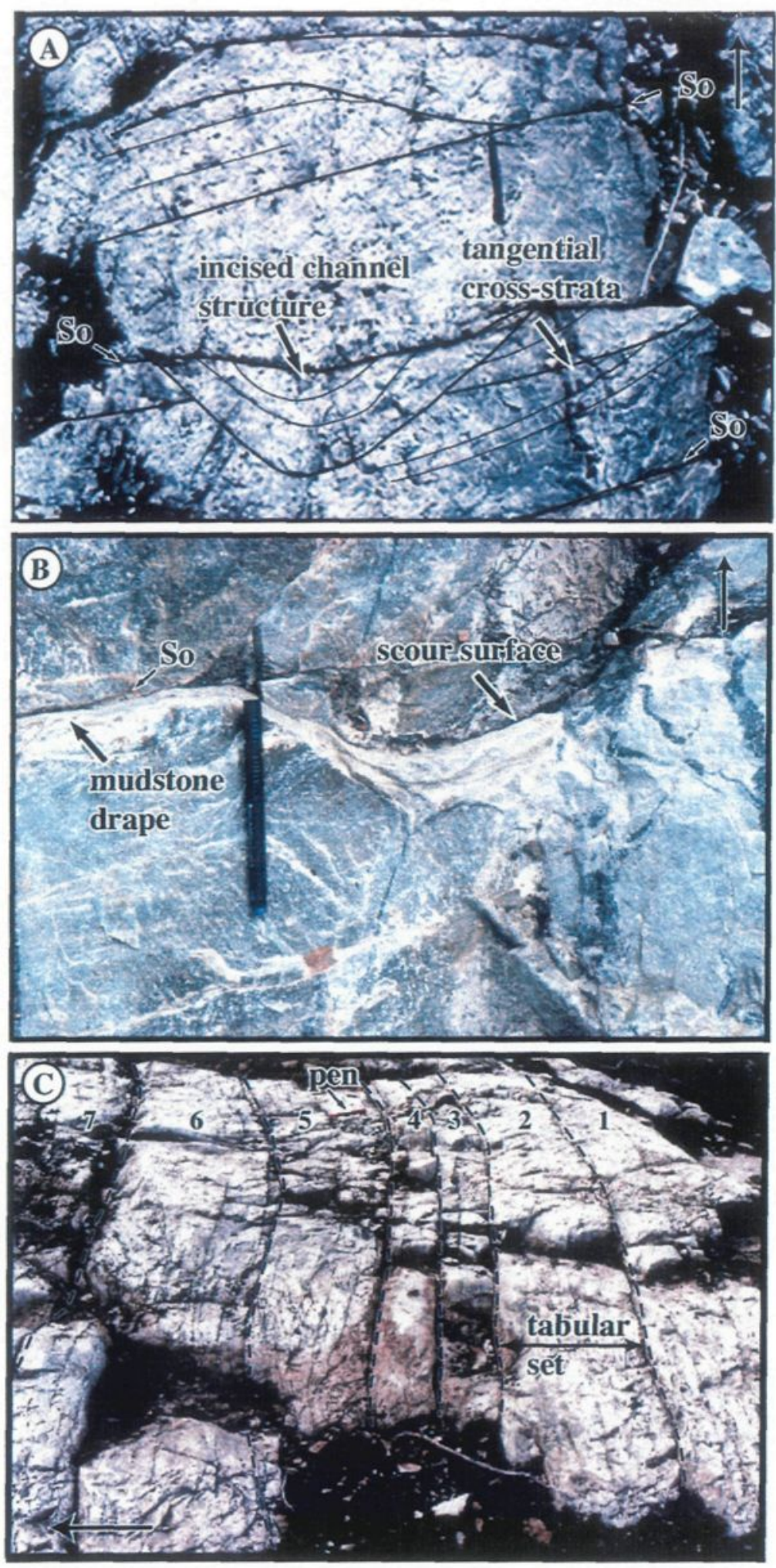

Plate 2.4 
and Figure 2.5 A are straight-crested bedforms. Together, these constructive sinuous and straight-crested bedforms typically involve high sediment transport rates with appreciable suspended load and bedload (Harms et al. 1975). The abundance of coarse- to very coarsegrained material indicates abundant sand supply and availability (Johnson \& Baldwin 1996). Small- to medium-scale cross-strata represent ripple-dunes that commonly form on the foresets of larger subaqueous sandwaves (Corcoran et al. 1998) or migrating sandwaves formed at moderate to lower current velocities than the large-scale cross-beds (Harmes et al. 1975; Prothero \& Schwab 1996).

Reactivation surfaces present in the QAL are a good indicator of changes in flow conditions, either through storms and/or tidal activity, and imply that the lateral advance of migrating bedforms was temporarily interrupted (Harmes et al. 1975). For example, sandwaves migrating during dominant tidal phases are modified by minor erosion during subordinate tidal phases, thus creating reactivation surfaces through temporary reversals of flow or change in flow velocity (Nio \& Yang 1991). Quartz-arenite beds lacking mudstone drapes indicate higher wave-action and/or a lack of slack-water periods between tides, thus inhibiting fine-grained material to fall out of suspension (Dalrymple 1992). Ripple marks superimposed on large-scale cross-beds may infer wave reworking of tidal sandwaves during quiescent periods within tidal cycles (Soegaard \& Eriksson 1985). Nio and Yang (1991) describe similar features attributing them to subordinate tidal current energy conditions between dominant tidal phases.

The QAL, in location C-1 (Plate 2.3 A \& B, Figure 2.5), shows a predominantly unidirectional paleocurrent pattern consistent with a strong oceanic current with a subordinate tidal current; the former may have been generated by shoaling waves (Ashley 1990). Foresets of the large-scale planar and tangential-cross bedding with predominant unidirectional paleocurrent directions, exemplified in Figure 2.5, show striking resemblance to the migrating sandwaves described by Simonson (1984) and Strachan (1986). Bimodal, bipolar current features are also present in the QAL, (location C-2 \& C-3) as seen in the Rose diagrams in Figure 2.6. These current patterns could be interpreted as 


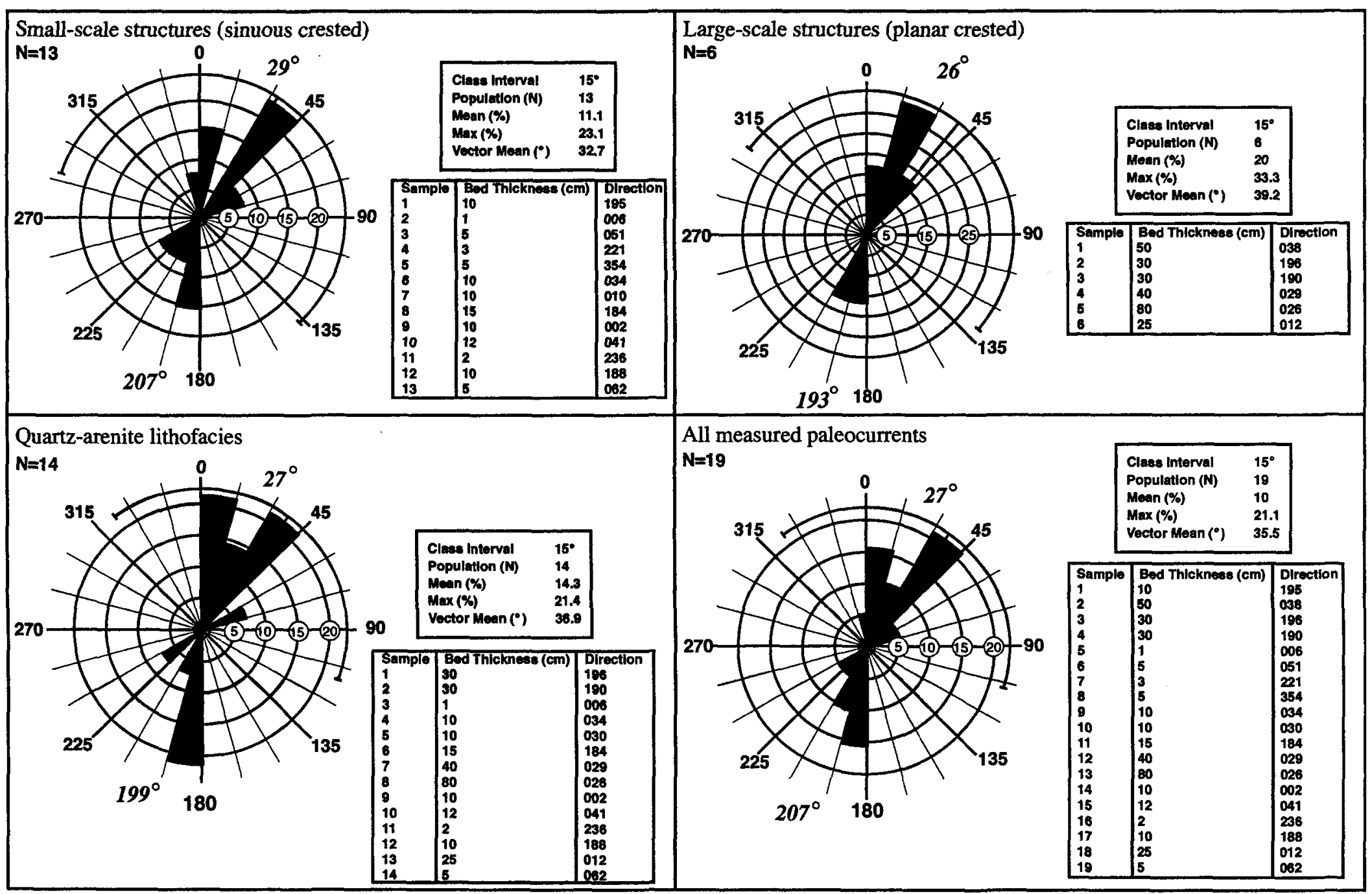

Figure 2.6. Results of paleocurrent analyses from the Beniah Formation. In all four rose diagrams, a bimodal/bipolar distribution of current directions is revealed. The mean direction is indicated on each diagram in italics. 
the product of sigmoidal crests within large tabular sets developing under the influence of rising and falling tides. The omnipresence of mudstone drapes supports this inference.

A high-energy, shallow-water, tide- and wave-influenced environment is proposed for the QAL based on the omnipresence of tangential cross-beds, minor planar cross-beds, composite cross-strata, reactivation surfaces, mudstone drapes and the overall tabular geometry. Tidal currents are inherently unsteady (Ashley 1990) and consequently, a variety of sedimentary structures are possible.

\subsubsection{Sandstone-Siltstone Lithofacies}

The sandstone-siltstone lithofacies (SaSL) is characterized by alternating units of sandstone and subordinate siltstone beds (Plate 2.5 A). The SaSL ranges in thickness from 10-16 m with a mean thickness of $14 \mathrm{~m}$ and comprises $\sim 20 \%$ of the Beniah Formation. Medium- to very coarse-grained sandstone beds $(5-30 \mathrm{~cm}$ thick) contain abundant tangential composite cross-strata, ripples, planar to wavy beds, reactivation surfaces and mudstone drapes. The mudstone drapes measure between $0.5 \mathrm{~cm}$ and $3 \mathrm{~cm}$ thick and are composed primarily of clay-size material. Bed continuity is locally recognized on large outcrops, however limited outcrop exposure inhibits assessment of the lateral extent of beds.

Sandstone beds contain low-angle cross-beds, $\leq 20 \mathrm{~cm}$ in thickness. The small- to medium-scale cross-laminae reveal opposing foreset orientations and are often coated by mm-thick mudstone drapes, which are prevalent on the upper bedding surfaces as well (Plate 2.5 B). Ripple marks, $0.5-5 \mathrm{~cm}$ thick, display both sigmoidal and complex discordant forms and are often delineated by thin mudstone laminae (Plate $2.5 \mathrm{C}$ ). Planar to wavy beds, containing parallel laminae $(<0.5 \mathrm{~cm})$ are interstratified with the cross-bedded sandstones. Similar to the QAL, the SaSL contains abundant reactivation surfaces. Decimeter-size channel scours locally transect primary bedding planes and cross-beds. Subordinate, massive to poorly stratified siltstone interbeds, $2-16 \mathrm{~cm}$ thick (mean thickness $\leq 10 \mathrm{~cm}$ ) contain abundant parallel planar to wavy laminae (Plate 2.5 D). 
Plate 2.5 (A) Sandstone-siltstone lithofacies (SaSL) characterized by intercalated tabular sets of cross-bedded sandstone and finer-grained, predominantly planar, parallel laminated siltstone beds. Pen is $15 \mathrm{~cm}$ and arrow indicates tops towards the south.

Plate 2.5 (B) Planar bedding and tangential cross-bedding in the sandstone-siltstone lithofacies. Mudstone drapes both the planar beds and cross-beds. Pen is $14.5 \mathrm{~cm}$ long and points towards the younging direction (southward).

Plate 2.5 (C) Close-up of SaSL revealing complex small-scale ripple marks and planar to wavy laminae capped by thin veneers of mudstone. Diameter of coin is approx. $2.5 \mathrm{~cm}$ and arrow indicates younging direction.

Plate 2.5 (D) Close-up of medium- to coarse-grained sandstone and thin siltstone interbeds. Coin diameter is $2.5 \mathrm{~cm}$ and arrow indicates south-younging tops. 

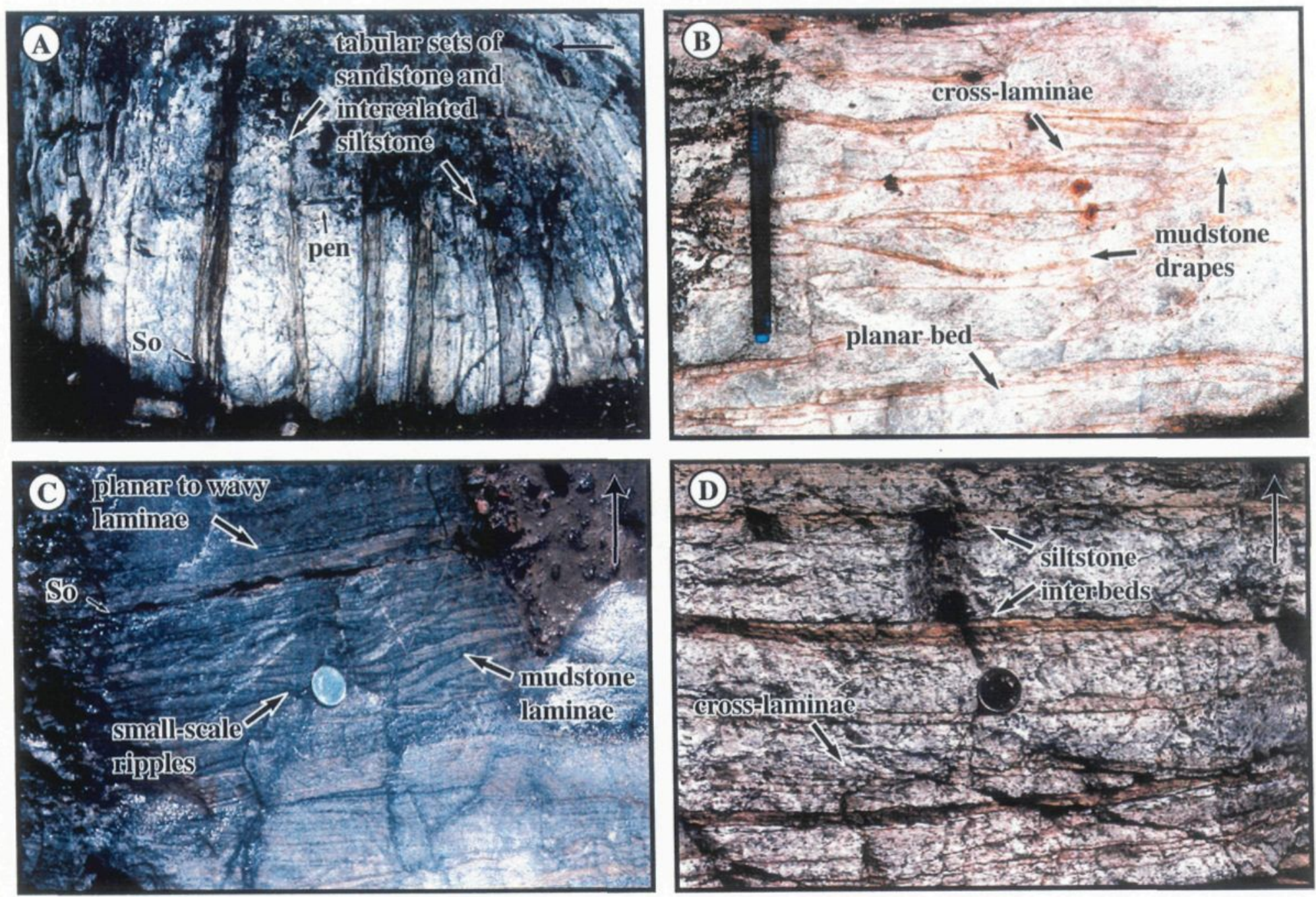

Plate 2.5 
Rose diagrams, plotted from cross-bedding structures exposed on 3-D surfaces, demonstrate distinct paleocurrent patterns and clearly reveal an overall bimodal/bipolar distribution for both the SaSL (Figure 2.6) and portions of the QAL containing larger-scale sedimentary features. Small-scale structures, such as ripples and tangential cross-lamina show strongly opposing paleocurrent directions for the $345-15^{\circ}$ and $180-210^{\circ}$ ranges and a slightly more dominant current for the $30-75^{\circ}$ versus the $210-240^{\circ}$ range. Large-scale structures, including planar and tangential cross-strata, derived mostly from the QAL, indicate a bi-directional distribution with a dominant current in the upper right quadrant $\left(30-45^{\circ}\right)$.

The SaSL is found in all study areas, but is most abundant in locations C-1 and C-2 (Figure 2.1). The contacts between the SaSL and the underlying siltstone-sandstone lithofacies is often gradational, occurring over $0.5-1 \mathrm{~m}$. The SaSL is generally overlain by coarse- to very coarse-grained QAL (erosive contact), with exception to location C-2 where a faulted and sheared contact with overlying mafic pillowed flows is observed. Figure 2.7 is an outcrop sketch of the SaSL from location C-2. Blow-ups of specific locations display complex sedimentary structures. Tangential cross-beds reveal opposing current directions and are draped by thin mudstone laminae on both foresets and bounding surfaces (So). The tabular geometry of the SaSL is also clear and this outcrop provides one of the rare occasions to be able to trace the lithofacies laterally over several metres. Also indicated is the relatively abrupt transition from the underlying siltstone-sandstone lithofacies.

\subsubsection{Interpretation}

Based on the salient structures, including composite cross-strata, reactivation surfaces, mudstone drapes and the overall tabular geometry of the bedforms, a tide- and wave-dominated subtidal setting is envisaged for the SaSL with possible storm activity (Homewood \& Allen 1981; Dalrymple 1992). The predominant sediment transport processes include traction currents for the medium- to coarse-grained sandstone and suspension sedimentation for the siltstone interbeds and mudstone drapes (Prothero \& Schwab 1996). 


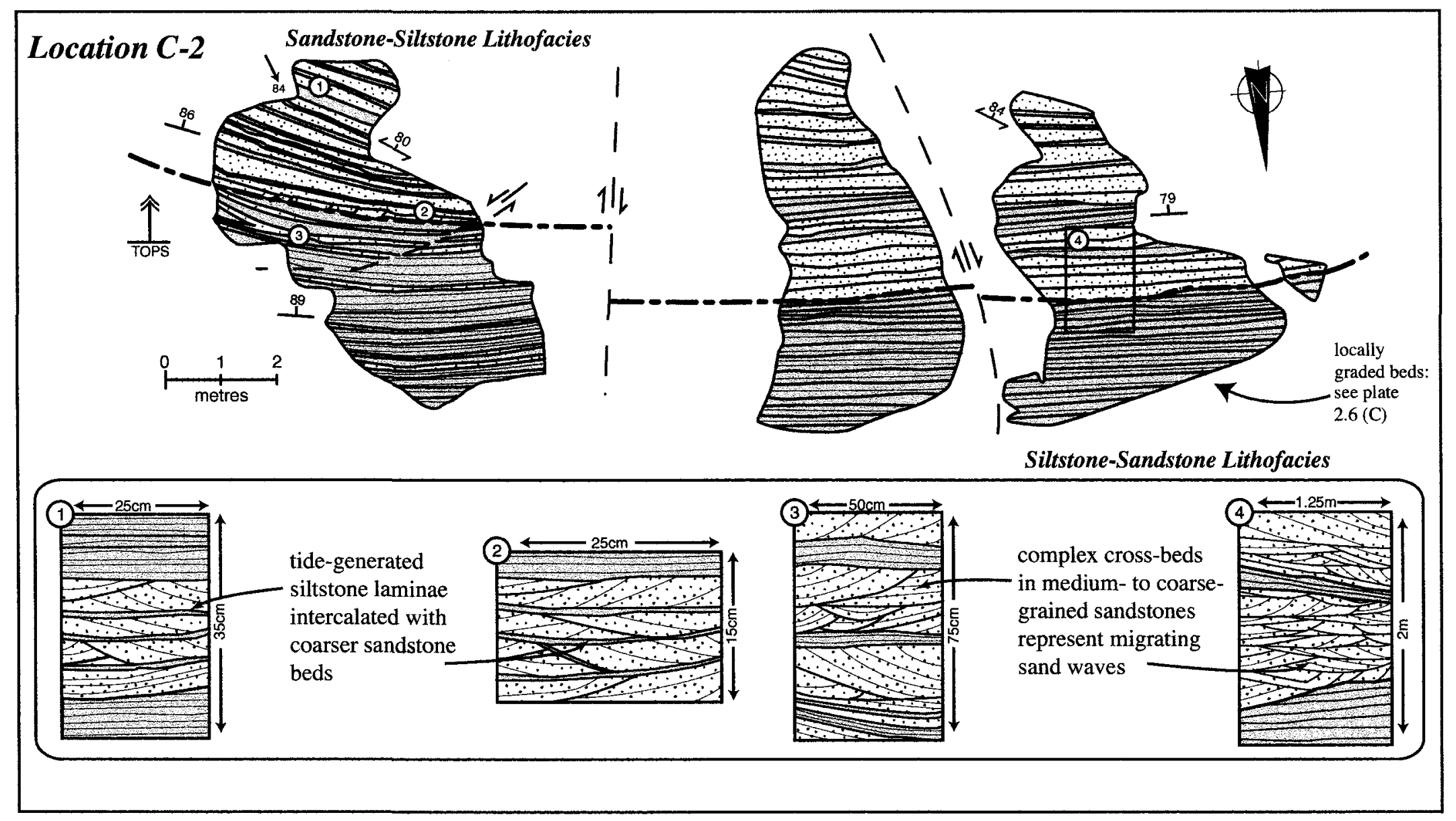

Figure 2.7. Outcrop sketch illustrating the transition from siltstone-sandstone to sandstone-siltstone lithofacies (from bottom to top). Enlarged detailed sketches indicate the complex composite sedimentary structures and tabular geometry of the sandstone-siltstone lithofacies as well as alternations between thin siltstone laminae and coarser-grained sandstone beds. 
Small- to medium-scale composite cross-strata are characteristic of migrating sandwaves produced by tidal or wave-induced currents in a low to moderate flow regime (Allen 1981; Dalrymple 1992). Discordant ripple marks (Plate $2.5 \mathrm{C}$ ) represent migrating combined-flow and wave ripples (Harms et al. 1975; Reineck \& Singh 1980) and sandstone/siltstone interbeds with ripple marks are related to small amplitude sandwaves (Homewood \& Allen 1981). Paleocurrent data strongly implies tidal influence for the SaSL as bimodal/bipolar orientation of foreset laminae are characteristic of tide-dominated environments (Klein 1970; Soegaard \& Eriksson 1985; Strachan 1986; George 1994).

Mudstone drapes on the foresets of composite cross-strata are the result of highly fluctuating wave-energy conditions and represent migrating sandwaves under the influence of strongly asymmetrical tides (Allen 1981). The drapes were deposited during the slackwater stage of tidal periods where low flow velocities allowed for silty material to sink out of suspension (Soegaard \& Eriksson 1985; Dalrymple 1992; George 1994). Reactivation surfaces represent flow unsteadiness and are related to variations in tidal flood-ebb cycles (de Mowbray \& Visser 1984). More specifically, subordinate currents may erode the lee side of the dominant current sandwaves prior to the dominant current taking over again. Planar laminated sandstone beds in the SaSL can be attributed to swash and backwash wave action during tidal phases (Reineck \& Singh 1980). However, the close spatial relationship with the alternating sandstone and siltstone could also reflect storm influence with sandstone beds deposited during peak storm activity and muddy layers settling from suspension as the storm quelled (Mueller \& Dimroth 1987).

\subsubsection{Siltstone-Sandstone Lithofacies}

Approximately $17 \%$ of the Beniah Formation is composed of the $2-28 \mathrm{~m}$-thick siltstone-sandstone lithofacies (SiSL). Two sublithofacies are distinguished based on sedimentary structures, color, their position relative to the other lithofacies and the presence or absence of Fe-mineralization. These include the wavy- to planar-bedded siltstone and iron-formation sublithofacies. 
The wavy- to planar-bedded siltstone sublithofacies (WPSL) is defined by the presence of $>50 \%$ silt-sized particles with subordinate $(<50 \%)$ sand-sized material and constitutes $-67 \%$ of the SiSL. This lithofacies is $5-13 \mathrm{~m}$ thick with a mean of $9 \mathrm{~m}$ and is characterized by $0.1-3$ m-thick siltstone beds containing planar to wavy laminae and rippled horizons, as well as local pebble lags. Siltstone beds are generally poorly stratified and appear massive (Plate $2.6 \mathrm{~A} \& \mathrm{~B}$ ), with exception to locally graded beds occurring over 4-7 $\mathrm{cm}$, as seen in location C-2 (Plate $2.6 \mathrm{C}$ ). Slightly coarser-grained beds contain parallel, planar to wavy laminae with 1-10 mm-thick spacing. Tangential unidirectional ripple marks are common in coarser beds and rarely exceed thicknesses of $0.5 \mathrm{~cm}$ (Plate $2.6 \mathrm{D}$ ). Local pebbly horizons $(5-15 \mathrm{~cm}$ thick) contain quartz grains $(0.3-1 \mathrm{~cm}$ thick) surrounded by finegrained sand to silt-size material.

The coarser-grained component of the SiSL includes predominantly fine-grained sandstone with subordinate medium- to coarse-grained interbeds. Fine-grained sandstone interbeds are 10-20 cm thick and appear massive and structureless. In contrast, the mediumto coarse-grained sandstone interbeds $(15-40 \mathrm{~cm}$ thick) contain planar and low-angle crosslaminae with both uni- and multi-directional foreset orientation. Sandstone interbeds are continuous along strike for several metres, though many pinch out laterally.

The SiSL commonly grades upward into medium- to coarse-grained sandstone with subordinate interbedded siltstone (i.e. the SaSL). Strata underlying the SiSL consists of very coarse-grained, cross-bedded quartz-arenites (QAL) with exception to one outcrop in location C-3, where the siltstone beds are in a sharp and abrupt contact with underlying quartz-pebble conglomerate (QPSL) (Figure 2.3). Two detailed stratigraphic columns (Figure 2.8) from study area C-1 show the sharp contact between the SiSL and underlying coarse-grained quartz-arenite beds (A) and the gradational contact between the SiSL and overlying SaSL (B). Stratigraphic column A illustrates the locally graded, wavy- to planarbedded and cross-bedded coarse-grained sandstone interbeds. At approximately 2.3 metres, the SiSL changes abruptly into the SaSL (indicated by the dashed line). Local pebble lags are also present. Stratigraphic column B indicates the sharp and abrupt contact between the QAL and SiSL. The SiSL contains planar to wavy laminae, ripple marks and thin, massive 
Plate 2.6 (A) Wavy- to planar-bedded sublithofacies (WPSL) containing planar, parallel laminated locally graded siltstone beds (darker coloured) with medium- to coarse-grained sandstone interbeds. Field book is approximately $17.5 \mathrm{~cm}$ long and the arrow indicates a south-younging direction.

Plate 2.6 (B) Close-up of the WPSL revealing alternating bands of fine- to mediumgrained sandstone and darker siltstone layers. Pencil is $13.5 \mathrm{~cm}$ long and points southward (i.e. tops).

Plate 2.6 (C) Close-up of graded bedding in siltstone. Coin is approx. $2.5 \mathrm{~cm}$ in diameter and top is towards the south, as indicated by the arrow.

Plate 2.6 (D) Sedimentary structures characteristic of the wavy- to planar-bedded sublithofacies including planar and wavy laminae as well as ripple marks. Tip of pen is $3.5 \mathrm{~cm}$ long and arrow indicates a south-younging direction. 

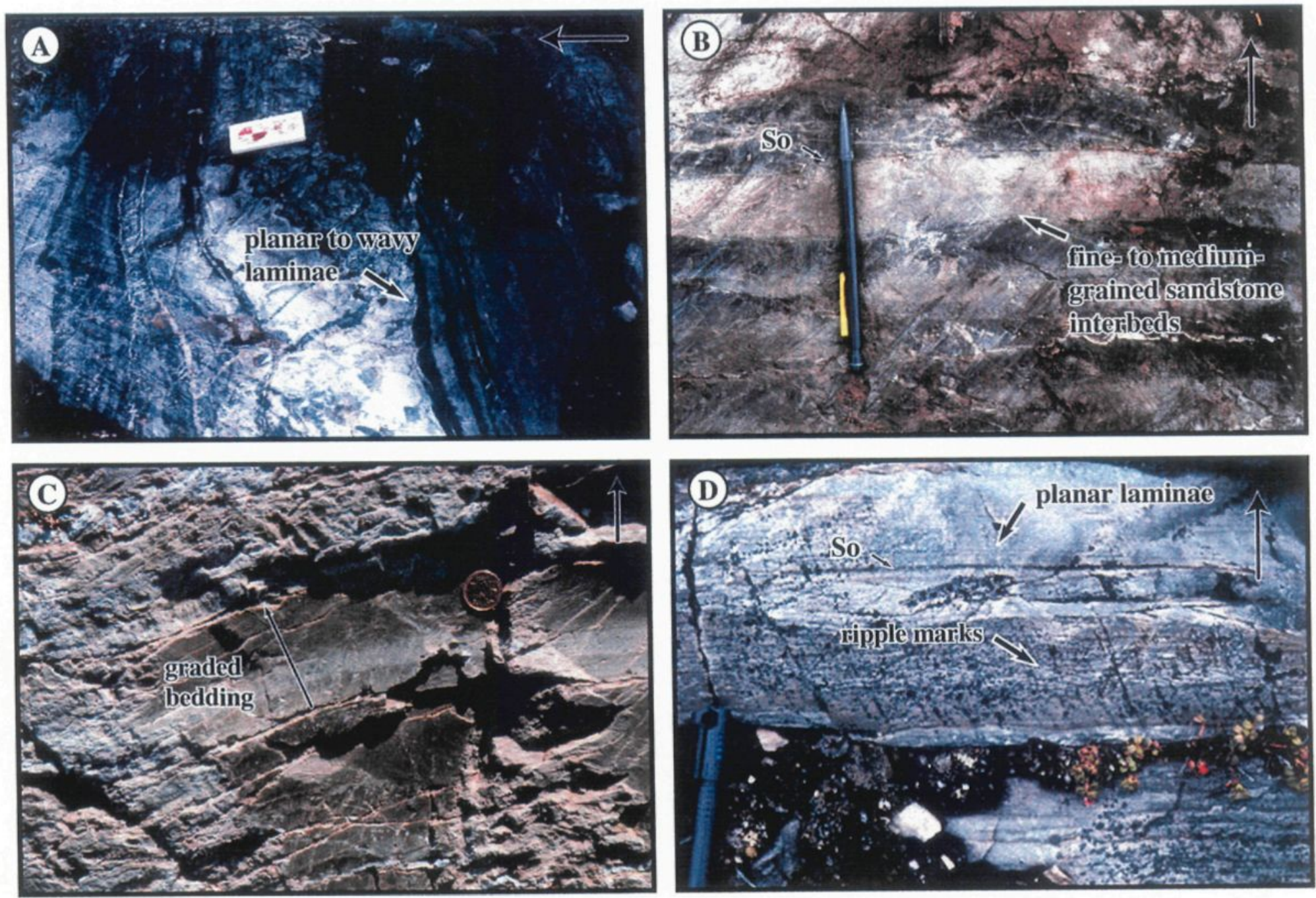

Plate 2.6 


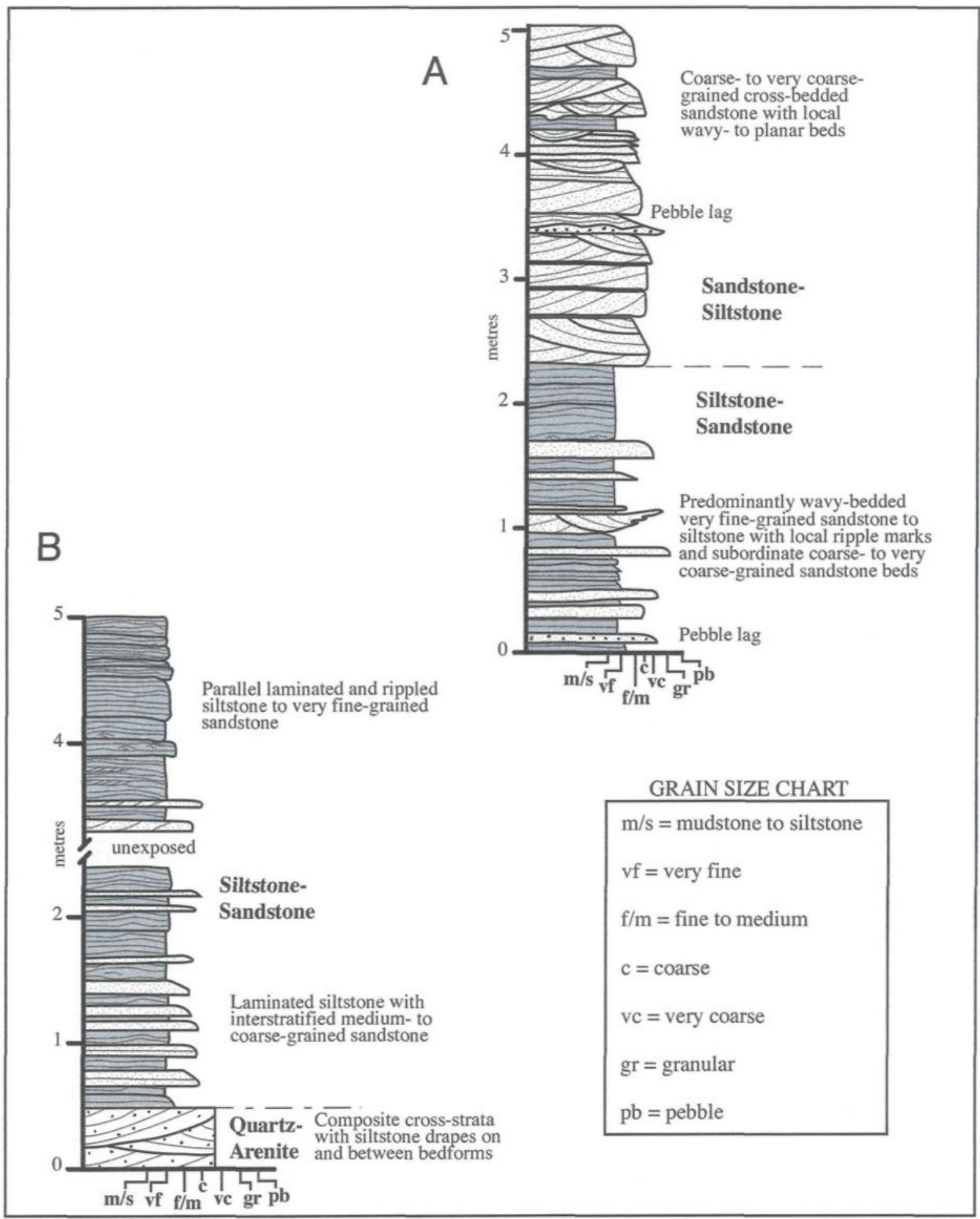

Figure 2.8. Detailed stratigraphic columns from Location C-1. Column A illustrates the transition from siltstone-sandstone to sandstone-siltstone. Column B shows the sharp contact between the quartz-arenite and overlying siltstone-sandstone lithofacies. 
to graded and cross-bedded sandstone interbeds, generally less than $10 \mathrm{~cm}$. The sharp contact between the QAL and overlying SiSL is indicated by the dashed line. The grain size chart shown in Figure 2.8 will be used for subsequent figures containing stratigraphic sections.

The iron-formation sublithofacies (IFSL), constituting $33 \%$ of the SiSL, is up to 28 $\mathrm{m}$ thick, but is generally less than $10 \mathrm{~m}$. The IFSL contains alternating bands of fine quartzrich silt-sized material and clay-rich layers (Plates 2.7 A and B). Dark clay-rich bands vary from extremely magnetic to nonmagnetic. Thickness of bands ranges from 1-10 $\mathrm{mm}$ and 2$10 \mathrm{~cm}$ with relatively equal amounts of quartzose and clay-rich material (Plate $2.7 \mathrm{C}$ ) Locally, this sublithofacies is extremely distorted, whereas other outcrops appear undeformed. The primary sedimentary structures observed are planar laminae with local minor wavy laminae. The IFSL is encountered primarily in study areas B and D, but local outcrops are exposed throughout the Beniah Lake area. It is found overlying the QAL and SBSL with sharp, non-erosive contacts in both cases. At location D, the IFSL is overlain by the SaSL. A $120 \mathrm{~m}$ composite stratigraphic section from location D is illustrated in Figure 2.9. The sharp, non-erosive contact between the SBSL and overlying IFSL is illustrated. The contact between the IFSL and overlying SaSL is abrupt and depositional. Several 3 to $30 \mathrm{~m}$-thick mafic dykes cross-cut the stratigraphy.

\subsubsection{Interpretation}

Sedimentary structures of the SiSL are consistent with tide-, wave- and possible storm influence. Deposition in a relatively calm setting with wave reworking and occasional high sediment influx is envisaged. Sedimentary features, such as graded beds and ubiquitous planar to wavy parallel laminae, are indicative of low-energy conditions whereby sediment is predominantly deposited from suspension (Prothero \& Schwab 1996). The cross-bedded and planar-bedded sandstones represent wave-generated bedforms (Reineck \& Singh 1980; George 1994) that develop as ripples and dunes (Corcoran et al. 1998). Combined-flow and current ripples with abundant mudstone drapes imply a combination of wave and tide influence (Klein 1970; Harms et al. 1975). Local pebble lags 
Plate 2.7 (A) Iron-formation sublithofacies (IFSL) with alternating cm-thick bands of quartz-rich and clay/magnetite-rich material. Pen is $13.5 \mathrm{~cm}$ long and younging direction is inferred to be southward, indicated by the arrow.

Plate 2.7 (B) Close-up of the iron-formation sublithofacies. Pen is $13.5 \mathrm{~cm} \cdot$ long and points in the younging direction (i.e. towards the south).

Plate 2.7 (C) Alternating bands of cm-thick quartz-rich and Fe-rich material. Field book is $17.5 \mathrm{~cm}$ and the arrow indicates tops. 


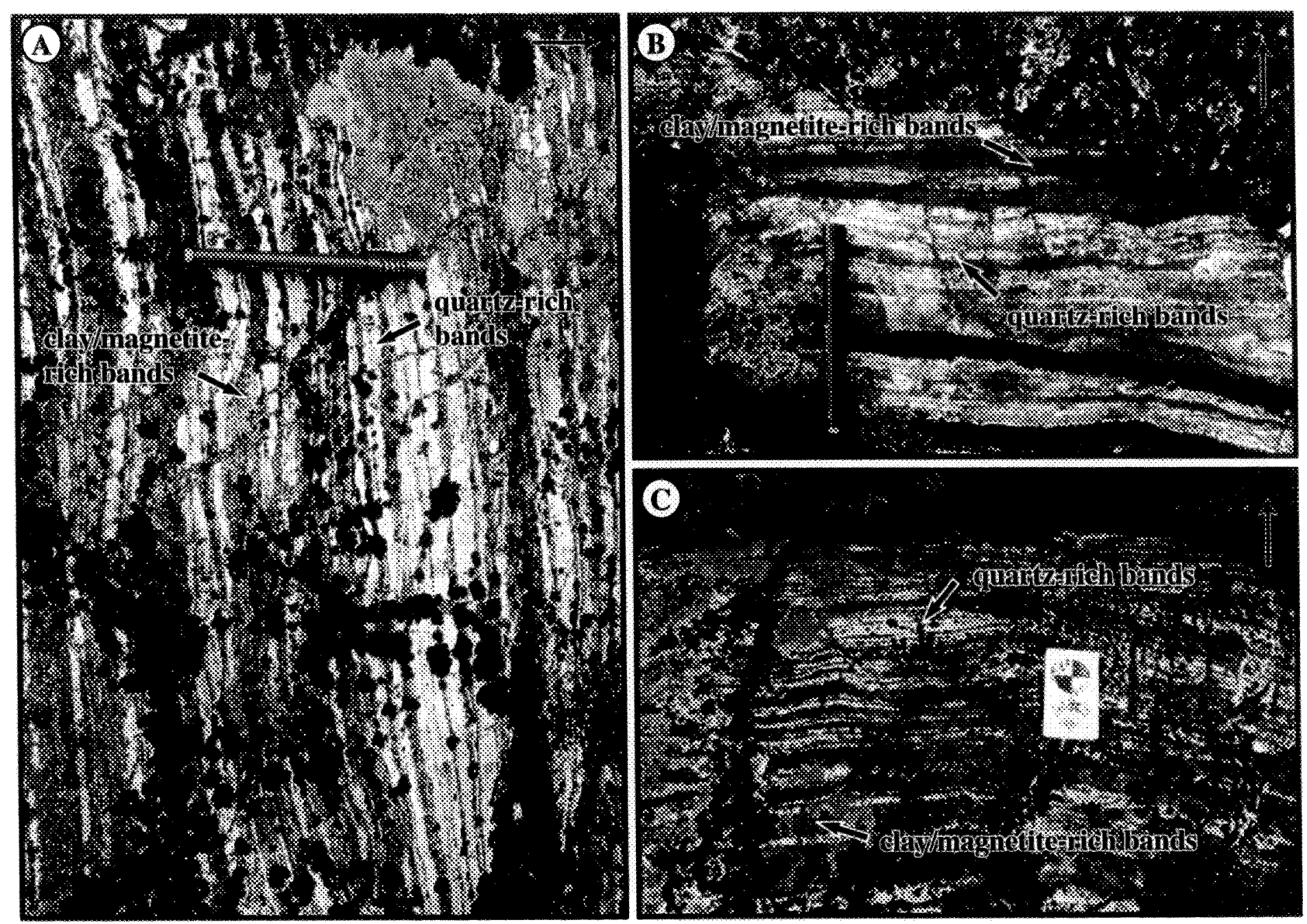

Plate 2.7 


\section{Location D:}

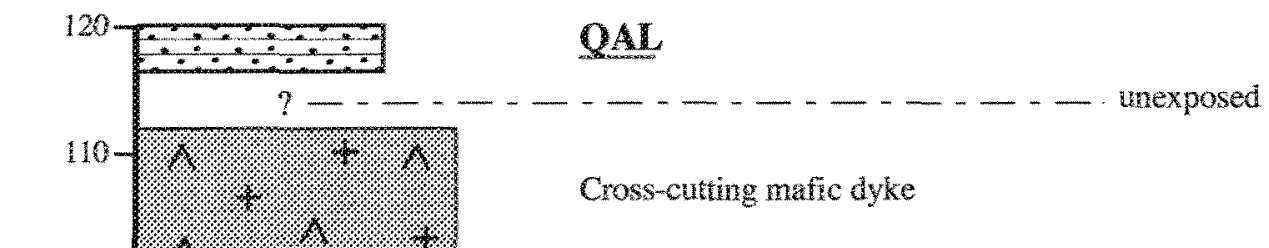

SaSL

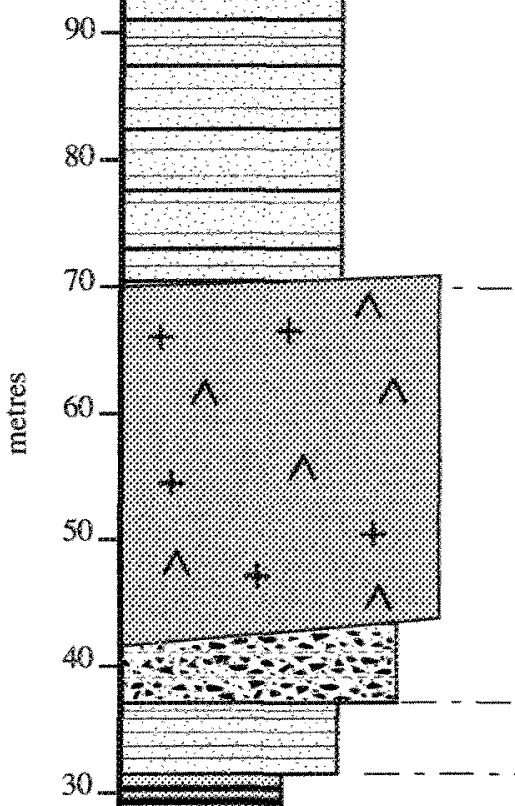

Planar-bedded sandstone with minor siltstone beds

Cross-cuting mafic dyke

\section{SBSL}

Angular fragments of quartzarenite siltstone and iron-formation (sublithofacies of CL)

\section{SaSL}

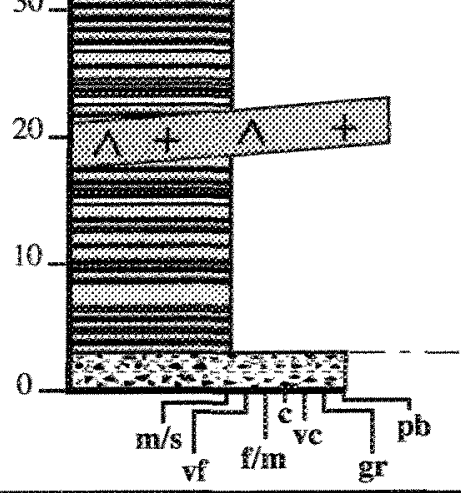

\section{IFSL}

Altemating layers of quartzrich and magnetike-rich bands (stblithofacies of SISL)

\section{SBSL} sharp, non-erosive contact

Figure 2.9. Stratigraphic column from location $D$ illustrating the various lithofacies and contact relationships. IFSL $=$ iron-fornation sublithofacies; $\mathrm{Cl}=$ conglomerate lithofacies; SaSL = sandstone-siltstone lithofacies; SBSL = sedimentary breccia sublithofacies; SiSL = siltstonesandstone lithofacies; QAL = quartz-arenite lithofacies. 
formed from short influxes of high-energy wave conditions, possibly during storms (Duke \& Prave 1991; Prave et al. 1996). Interbedding of massive and cross-bedded sandstone with graded and laminated siltstone can be attributed to storms whereby siltstone laminae settled from suspension with sandstone interbeds deposited during periodic elevated wave-energy conditions (Mueller \& Dimroth 1987).

Mineralization in the IFSL is considered post-depositional and diagenetic. In latestage diagenesis, amorphous aluminum, iron and magnesium ions are incorporated and readily available (Foscolos 1990). Chown et al. (2000) describe Archean replacement-type iron-formations from the Abitibi greenstone belt in Quebec. Replacement origin is described as being difficult to determine, a consequence of metamorphism, although primary and/or secondary volcanic sources are good potential contenders for the diagenetic fluid. The origin of the Beniah Lake iron-formations therefore, could be the result of diagenetic replacement of Fe-rich clays in the proposed shallow-water setting that may be linked to local volcanogenic and/or hydrothermal processes.

\subsection{Relationship Between Volcanic and Sedimentary Rocks}

Mafic volcanic flows are located in the central Beniah Lake region. The volcanic rocks are primarily pillowed with well-formed bun-shaped forms and $\mathrm{mm}$ - to cm-thick chilled margins. Pillow size ranges from $10 \times 10 \mathrm{~cm}$ to $30 \times 60 \mathrm{~cm}$. Locally, pillow keels are identifiable and indicate a south-younging direction. These volcanic rocks differ distinctly from the other mafic volcanic units of the area, a supposition based on the spatial relationship with the sedimentary rocks of the Beniah Formation.

Two outcrops from study area $B$ reveal spatially related mafic volcanic and sedimentary rocks (Figure 2.10 ). The first outcrop (A) shows fine-grained sedimentary rocks of the SiSL interstratified with massive and pillowed flows. The outcrop is not extensive and deformation is relatively high in this area, however this provides evidence that volcanic activity had occurred during or shortly after the deposition of the ca. $2.8 \mathrm{Ga}$ sedimentary rocks. Evidence from the second outcrop $(B)$ is more convincing, as a depositional contact between the sedimentary rocks and overlying pillowed flows is 


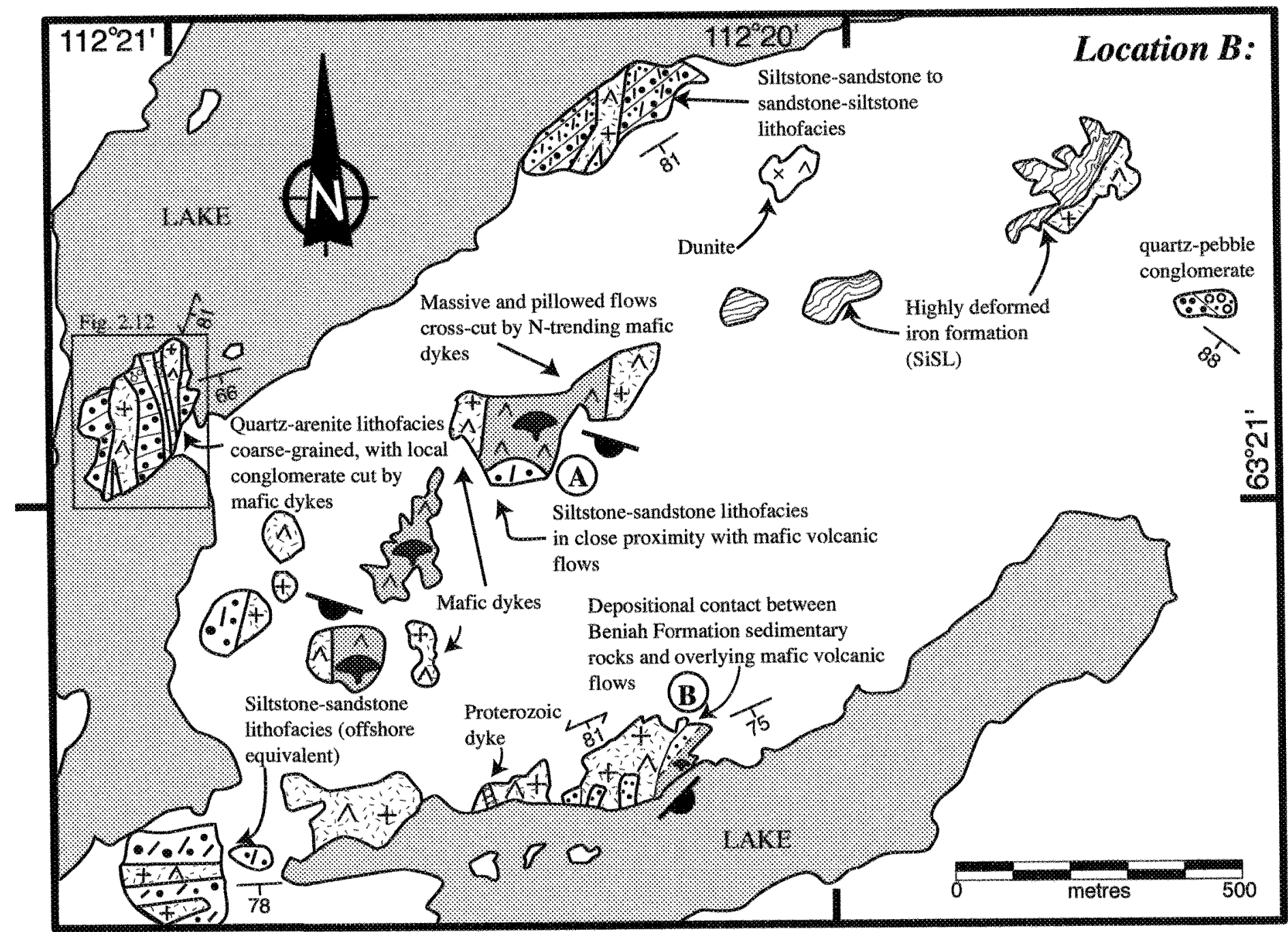

Figure 2.10. Regional map of location B in the north-central Beniah Lake area. Area (A) indicates interstratification between volcanic flows and sedimentary rocks. Area (B) displays the depositional contact observed between the the siltstone-sandstone lithofacies and the overlying mafic pillowed flows. 
observed. A 25 metre composite stratigraphic section of outcrop B, illustrating the contact relationships between the underlying sedimentary rocks and overlying pillowed flows, as well as the cross-cutting mafic dykes are seen in Figure 2.11 . Over a distance of $10 \mathrm{~m}$, coarse- to very coarse-grained rocks from the QAL are cut by $\mathrm{N}$-trending mafic dykes and are overlain by approximately $4 \mathrm{~m}$ of fine-grained parallel laminated volcaniclastic siltstone (Plate $2.8 \mathrm{~A} \& \mathrm{~B}$ ). The siltstone is conformably overlain by mafic subaqueous flows ( $\geq 20$ $\mathrm{m}$ thick) containing well-formed pillows with $\mathrm{cm}$-thick chilled margins and keels (Plate 2.8 A, B, \& C).

Outcrop B-2 clearly indicates that local subaqueous volcanism was related to the deposition of the ca. $2.8 \mathrm{Ga}$ sedimentary rocks. It is conceivable that the volcaniclastic SiSL overlying the QAL are reworked hyaloclastite resulting from erosion of earlier flows and some of the cross-cutting mafic dykes may potentially have been feeders to the overlying pillowed flows.

\subsection{Cross-Cutting Mafic Dykes}

Numerous mafic dykes, metres to tens of metres thick, intruded the Beniah Formation, thus complicating stratigraphic correlation. In some areas, gabbroic dykes constitutes up to $50 \%$ of the exposed outcrop. Dyke cores are generally homogeneous, medium- to coarse-grained, with a grain size decrease towards the rim. Chilled margins are readily identified and local cm-sized anhedral plagioclase crystals are observed.

The overall orientation of the dykes is North-South, which is well-indicated in both locations $B$ and $C$ (Figure 2.1). In other areas, such as the fault zone (location A), the relationship is less well-defined, probably a result of regional deformation. Figure 2.12 is a detailed map of a peninsula from area B-1 illustrating the crosscutting relationship between the sedimentary rocks and mafic dykes. The south-younging quartz-arenite, quartz-pebble conglomerate and minor siltstone-sandstone beds are cut by metre-thick dykes striking almost due north (i.e. perpendicular to bedding). In addition, quartz veins, up to $2 \mathrm{~m}$ thick, strike in approximately the same direction. 


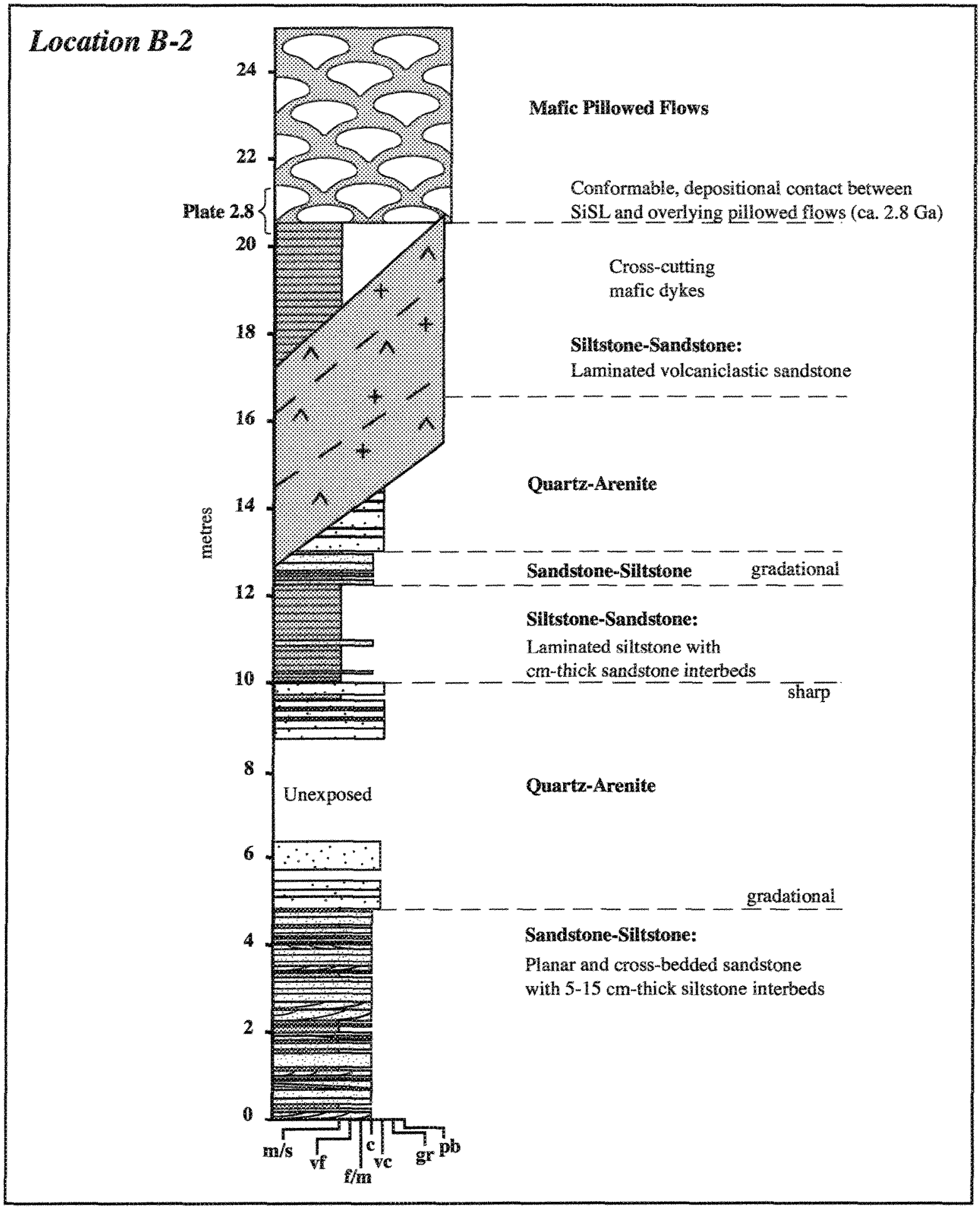

Figure 2.11. Composite stratigraphic section from location B-2 illustrating the depositional contact between the sedimentary rocks and overlying mafic pillowed flows. This section represents the stratigraphic top of the Beniah Formation. 
Plate 2.8 (A) Conformable contact between the volcaniclastic siltstone and overlying mafic pillowed flows. Field book is $17.5 \mathrm{~cm}$ long and arrow indicates the younging direction based on pillow tops.

Plate 2.8 (B) Close-up of the sharp depositional contact between the sedimentary and volcanic rocks. The top of the photograph contains fine-grained volcaniclastic siltstone and the bottom half shows the mafic pillowed flows. Hammer is approximately $30 \mathrm{~cm}$ long and points in the younging direction.

Plate 2.8 (C) Close-up of pillows situated directly above the conformable contact. The pencil is $14 \mathrm{~cm}$ long and the keel of the pillow, near the base of the pencil, suggests a polarity towards the south. 


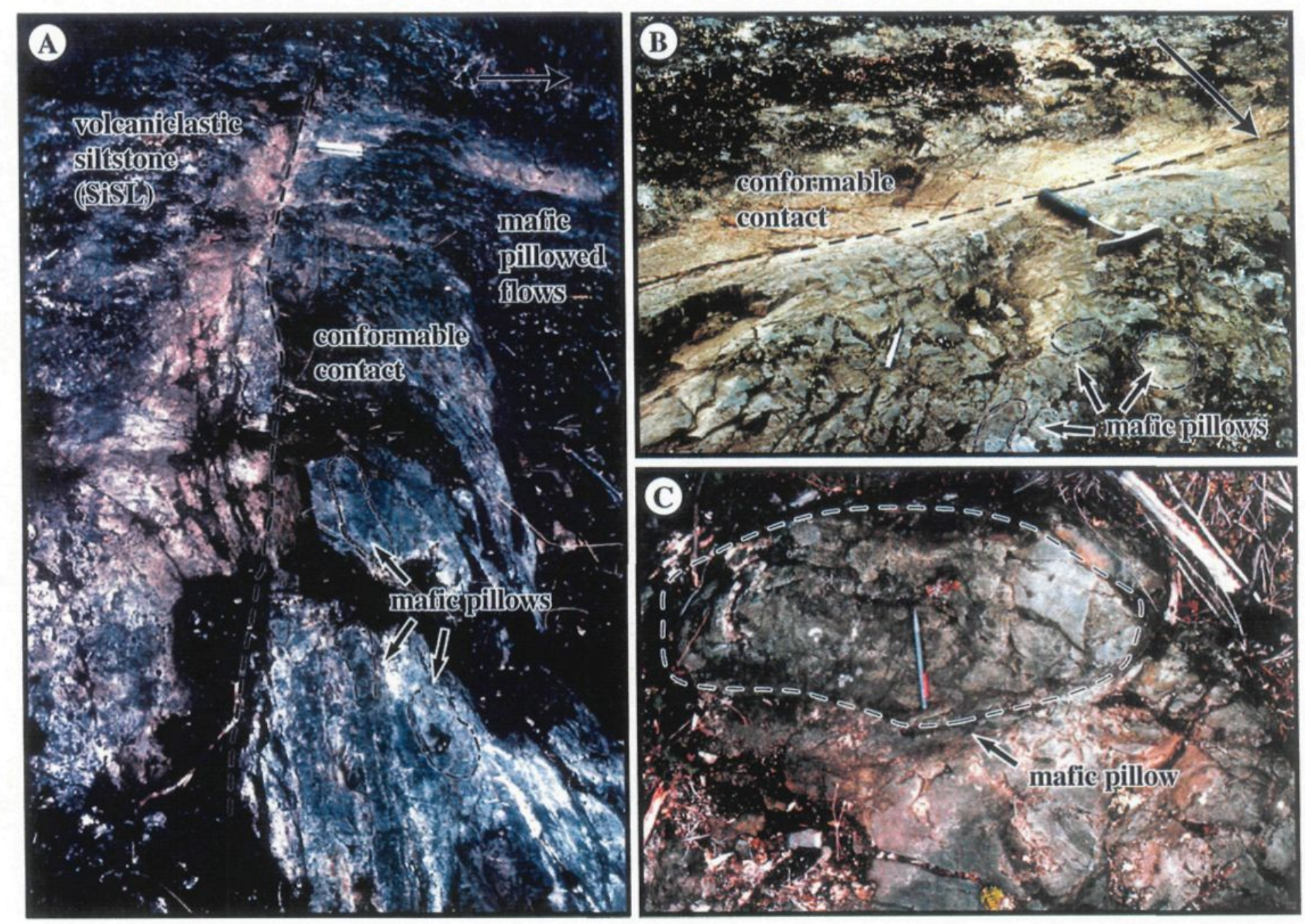

Plate 2.8 


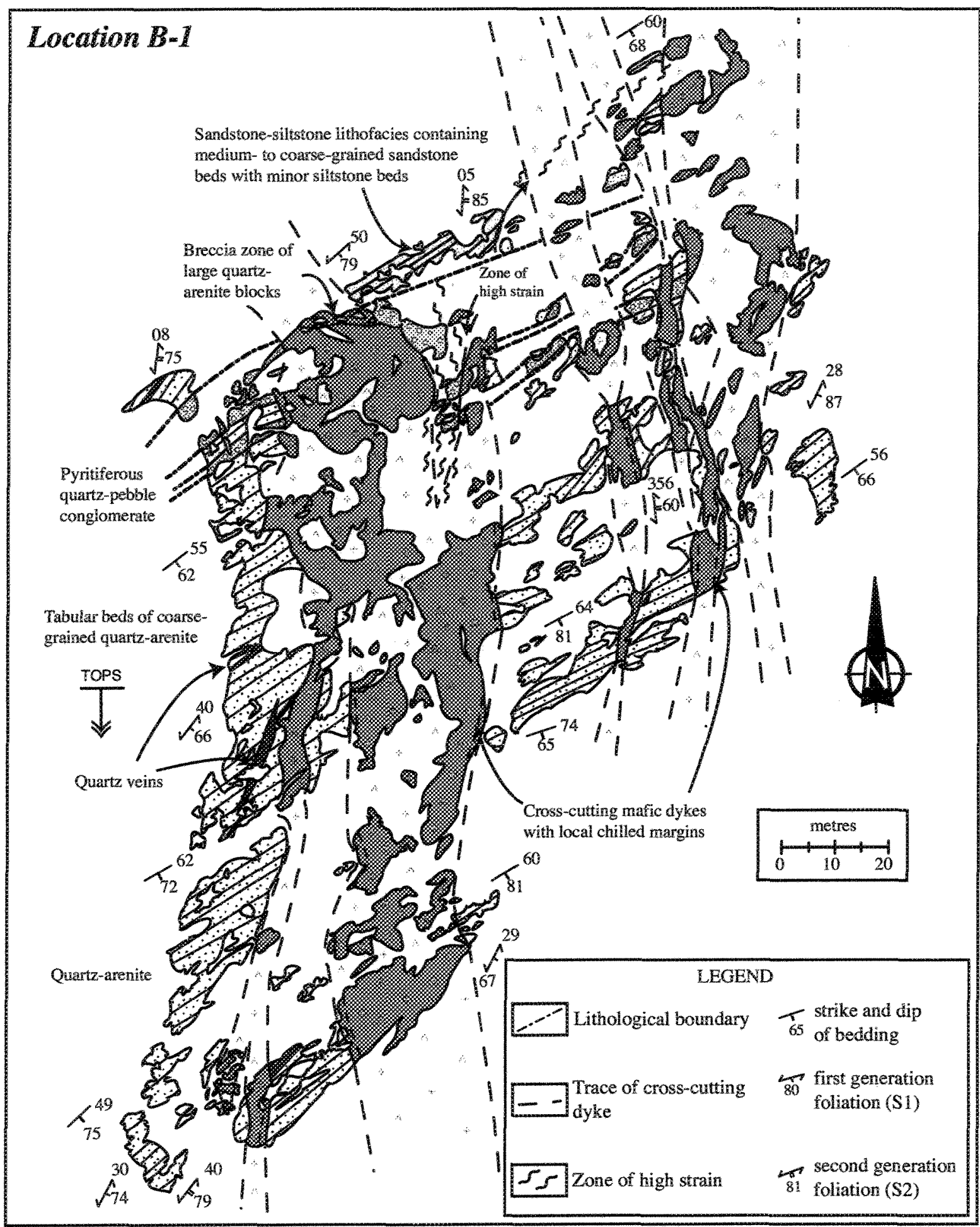

Figure 2.12. Regional map of location B-2 in the north-central Beniah Lake area illustrating the cross-cutting relationship between the mafic dykes and sedimentary rocks of the Beniah Formation. Sedimentary rocks young to the south (ie towards the bottom of the page). 


\subsection{Petrography of the Lithofacies}

The principal reasons to study the petrography of the Beniah Formation include: 1) distinguishing microscopically between the distinct lithofacies; 2) classifying the rocks properly based on composition using ternary diagrams (Folk 1980) with the aid of pointcounting; 3) identifying source of framework grains; and 4) evaluating the prevalence of chemical weathering. These sedimentary rocks have been metamorphosed, however primary grain shapes and sizes are locally preserved, hence where possible, textural descriptions will be given.

\subsubsection{Conglomerate Lithofacies}

All five samples from the $\mathrm{CL}$ are clast-supported, quartz-pebble conglomerates collected from study areas B and C. Based on the measuring of more than 300 grains, approximately $55 \%$ of the quartz clasts range in size from $2-5 \mathrm{~cm}$ (granular to pebble), with $30 \%$ measuring between 1 and $2 \mathrm{~mm}$ (very coarse-grained) and the remaining $15 \%$ at less than $1 \mathrm{~mm}$. Most clasts are subrounded to well-rounded with moderate to high sphericity, in the axis perpendicular to the stretching lineation. Quartz overgrowths between grains often give the impression of unusually large clasts, when actually, there may be as many as five separate quartz clasts with obliterated grain boundaries. The $\mathrm{CL}$ samples predominantly contain polycrystalline quartz with minor monocrystalline grains that exhibit undulatory extinction. Minor siltstone fragments from rip-up clasts are also present. The conglomerates are well-sorted and contain a silicified matrix containing smaller $(<2 \mathrm{~mm})$ quartz grains, muscovite, local chlorite porphyroblasts and lesser biotite.

Two samples collected from the SBSL contain angular to subangular clasts varying in size from $0.2-5 \mathrm{~cm}$. Clast types include medium- to very coarse-grained quartz-arenite siltstone and iron-formation, in decreasing abundance encased in a quartz- and muscoviterich matrix comprising $15-40 \%$ of the thin section. The quartz-arenite fragments contain large, well-rounded monocrystalline and polycrystalline quartz grains with varying degrees of recrystallization. 


\subsubsection{Quartz-Arenite Lithofacies}

More than 30 thin sections from the QAL were observed with 17 chosen for pointcounting. The QAL contains almost exclusively polycrystalline framework quartz (Table 2.2), with minor amounts of monocrystalline quartz with undulatory extinction. Grain boundaries, where visible, are generally sutured, a consequence of recrystallization and pressure solution (Plate $2.9 \mathrm{~A}$ ), however less deformed samples display subrounded to well-rounded quartz grains that are commonly well-sorted. Feldspars are rare and the heavy mineral suite is generally restricted to local subrounded chromite grains $(<1 \mathrm{~mm})$ and rare subrounded zircons. Chromite is distinguished from Fe-opaques by the presence of green fuchsitic laminae enveloping the detrital grains (generally more noticeable in hand sample).

The matrix is a subordinate component of the QAL samples and where present, consists of $<5 \%$ quartz $(<0.05 \mathrm{~mm})$. All samples have been silicified as well as recrystallized hence distinguishing between framework quartz and quartz-matrix is problematic. Muscovite is the most common mineral after quartz and constitutes a large portion of the matrix as well. Most samples contain less than $5 \%$ muscovite, although some have as much as $20 \%$.

\subsubsection{Sandstone-Siltstone Lithofacies}

Twenty-two thin sections from the sandstone beds of the SaSL were sampled for thin sections and eight of these were utilized for point-counting. The sandstones primarily contain framework grains of polycrystalline quartz with lesser amounts of monocrystalline quartz exhibiting undulatory extinction (Table 2.2). These grains range in size from $0.3-1.0$ $\mathrm{mm}$ with an average of $0.5 \mathrm{~mm}$ (i.e. medium- to coarse-grained) and are subangular to subrounded. Plagioclase is found only in samples from study area A and constitutes less than $2 \%$ of the thin section. Samples from the SaSL contain abundant micaceous material (5-21\%) with an average of $>15 \%$, giving an overall moderate to low textural maturity. The micas present in the SaSL include muscovite $(>80 \%)$, biotite $(10-15 \%)$ and chlorite $(<5 \%)$. These minerals are commonly acicular and often show preferential alignment parallel to the schistosity. Smaller grains of quartz $(<0.1 \mathrm{~mm})$ are visible within the matrix of the SaSL 


\section{Quartz-arenite lithofacies}

\begin{tabular}{|c|c|c|c|c|c|c|c|c|c|c|c|c|c|c|}
\hline Sample \# & $\mathrm{Qm}(\%)$ & $Q p(\%)$ & $Q(\%)$ & $Q p / Q$ & $\mathrm{P}(\%)$ & $\mathrm{K}(\%)$ & $F(\%)$ & $\mathrm{P} / \mathrm{F}$ & L.R(\%) & Musc. (\%) & Biot $(\%)$ & Chl. (9o) & Micas (\%) & Heavy Minerals \\
\hline CP-97-24 & 0 & 94.5 & 94.5 & 1 & 0 & 0 & 0 & 0 & 0 & 5.5 & 0 & 0 & 5.5 & 0 \\
\hline CP-97-27 & 0 & 76 & 76 & 1 & 0 & 0 & 0 & 0 & 0 & 18 & 6 & 0 & 24 & 0 \\
\hline CP-97-34 & 0 & 93.25 & 93.25 & 1 & 0 & 0 & 0 & 0 & 0 & 6.75 & 0 & 0 & 6.75 & 0 \\
\hline CP-97-39-X & 1.75 & 91.25 & 93 & 0.98 & 0 & 0 & 0 & 0 & 0 & 5.75 & 1 & 0 & 6.75 & 0.25 \\
\hline CP-97-1 & 2.5 & 91.25 & 93.75 & 0.97 & 0 & 0 & 0 & 0 & 0 & 5.5 & 0 & 0.75 & 6.25 & 0 \\
\hline CP-97-41A & 0 & 92.25 & 92.25 & 1 & 0 & 0 & 0 & 0 & 0 & 5.25 & 0.5 & 1.5 & 7.25 & 0.5 \\
\hline CP-97-41B & 0 & 95.75 & 95.75 & 1 & 0.5 & 0 & 0.5 & 0.5 & 0 & 1.75 & 1 & 1 & 3.75 & 0 \\
\hline CP. $97-42$ & 0 & 94.25 & 94.25 & 1 & 1 & 0 & 1 & 1 & 0 & 3.25 & 0.25 & 1.25 & 4.75 & 0 \\
\hline CP.97.43 & 1.5 & 93.25 & 94.75 & 0.98 & 0 & 0 & 0 & 0 & 0 & 5.25 & 0 & 0 & 5.52 & 0 \\
\hline $\mathrm{CP} \cdot 97-45$ & 0 & 93.5 & 93.5 & 1 & 0 & 0 & 0 & 0 & 0 & 6.5 & 0 & 0 & 6.5 & 0 \\
\hline$C P .9746$ & 0 & 87.5 & 87.5 & 1 & 0 & 0 & 0 & 0 & 0 & 12.25 & 0 & 0 & 12.25 & 0.25 \\
\hline CP. 97.48 & 0 & 92.25 & 92.25 & 1 & 0 & 0 & 0 & 0 & 0 & 7.75 & 0 & 0 & 7.75 & 0 \\
\hline CP-97-48-1 & 0 & 94.25 & 94.25 & 1 & 0 & 0 & 0 & 0 & 0 & 5.75 & 0 & 0 & 5.75 & 0 \\
\hline $\mathrm{CP} .9749$ & 0 & 95.75 & 95.75 & 1 & 0 & 0 & 0 & 0 & 0 & 4.25 & 0 & 0 & 4.25 & 0 \\
\hline CP. 97.57 & 0 & 89.75 & 89.75 & 1 & 0 & 0 & 0 & 0 & 0 & 10.25 & 0 & 0 & 10.25 & 0 \\
\hline CP-97-59 & 0 & 92.25 & 92.25 & 1 & 0 & 0 & 0 & 0 & 0 & 7.75 & 0 & 0 & 7.75 & 0 \\
\hline CP-97-60 & 0 & 80.25 & 80.25 & 1 & 0 & 0 & 0 & 0 & 0 & 19.75 & 0 & 0 & 19.75 & 0 \\
\hline MEAN & 0.34 & 91.01 & 91.35 & 1.00 & 0.09 & 0 & 0.09 & 0.12 & 0 & 7.72 & 0.51 & 0.26 & 8.50 & 0.06 \\
\hline
\end{tabular}

\section{Sandstone-siltstone lithofacies}

\begin{tabular}{|c|c|c|c|c|c|c|c|c|c|c|c|c|c|c|}
\hline Sample \# & $\mathrm{Qm}(\%)$ & $\mathrm{Qp}(\%)$ & $Q(\%)$ & $\mathrm{Qp} / \mathrm{Q}$ & $\mathrm{P}(\%)$ & $\mathrm{K}(\mathrm{O})$ & $F(\%)$ & $\mathrm{P} / \mathrm{F}$ & $\mathrm{LR}(\%)$ & Musc. (\%) & Biot. $(\%)$ & Chl. (9) & Micas (\%) & Heav y Minerals \\
\hline CP.97.17 & 15.5 & 82 & 97.5 & 0.84 & 0 & 0 & 0 & 0 & 0 & 2.5 & 0 & 0 & 2.5 & 0 \\
\hline CP.97-28 & 0 & 78.5 & 78.5 & 1 & a & 0 & 0 & o & 0 & 21 & 0 & 0.5 & $\frac{215}{215}$ & 0 \\
\hline $\mathrm{CP}-97-29$ & 0 & 86 & 86 & 1 & 0 & 0 & 0 & 0 & 0 & 13.25 & 0 & 0.5 & 13.75 & 0.25 \\
\hline $\mathrm{CP}-97-30$ & 0 & 88 & 88 & 1 & 0 & 0 & 0 & 0 & 0 & 10 & 0 & 1.75 & 11.75 & 0.25 \\
\hline CP-97-38 & 0 & 80.75 & 80.75 & 1 & 0 & 0 & 0 & 0 & 0 & 14.75 & 0 & 4.5 & 19.25 & 0 \\
\hline $\mathrm{CP}-97-51$ & 0 & 80.25 & 80.25 & 1 & 0 & 0 & 0 & 0 & 0 & 10.25 & 0 & 9.5 & 19.75 & 0 \\
\hline $\mathrm{CP}-97-52$ & 0 & 81.75 & 81.75 & 1 & 0 & 0 & 0 & 0 & 0 & 14.5 & 0 & 3.75 & 18.25 & 0 \\
\hline CP-98-13 & 0.75 & 73.75 & 74.5 & 0.99 & 0 & 0 & 0 & 0 & 0 & 25.5 & 0 & 0 & 25.5 & 0 \\
\hline MEAN & 2.03 & 81.38 & 83.41 & 0.98 & 0 & 0 & 0 & 0 & 0 & 13.97 & 0 & 2.56 & 16.53 & 0.06 \\
\hline
\end{tabular}

Table 2.2. Volumetric point-counting results of 17 samples from the quartz-arenite lithofacies and 8 samples from the siltstone-sandstone lithofacies. Grain parameters include $\mathrm{Q}=\mathrm{Qm}+\mathrm{Qp}$, where $\mathrm{Q}$ is total quartz, $\mathrm{Qm}$ is monocrystalline quartz and $\mathrm{Qp}$ is polycrystalline quartz; $\mathrm{F}=\mathrm{P}+\mathrm{K}$, where $\mathrm{F}=$ total feldspars, $\mathrm{P}=$ plagioclase and $\mathrm{K}=$ potassium feldspar; $\mathrm{L}, \mathrm{R}=$ lithic rock fragments; Micas $=$ Musc, + Biot. + Chl., where Musc. is muscovite, Biot. is biotite, and Chl. is chlorite. Four hundred points were counted for each sample. 
Plate 2.9 (A) Thin-section of a quartz-arenite in plane-polarized light (CP-97-59). Quartz grains have been recrystallized and primary sedimentary textures have been obliterated. Field of view is $5 \mathrm{~mm}$.

Plate 2.9 (B) Thin-section of siltstone containing predominantly phyllosilicates with minor quartz and Fe-opaques (CP-98-28). Alignment of the mica minerals represents the primary schistosity $\left(\mathrm{S}_{1}\right)$. Field of view is $5 \mathrm{~mm}$.

Plate 2.9 (C) Siltstone under cross-polars exposing the abundance of muscovite and other phyllosilicates, as well as recrystallized polycrystalline quartz (CP98-43). Field of view is $5 \mathrm{~mm}$.

Plate 2.9 (D) Iron-formation under cross-polars revealing the alternation between Ferich amphibole (grunerite?)/biotite-rich layers with abundant $\mathrm{Fe}$-opaques and quartz-rich layers (CP-98-05B). Field of view is $5 \mathrm{~mm}$. 

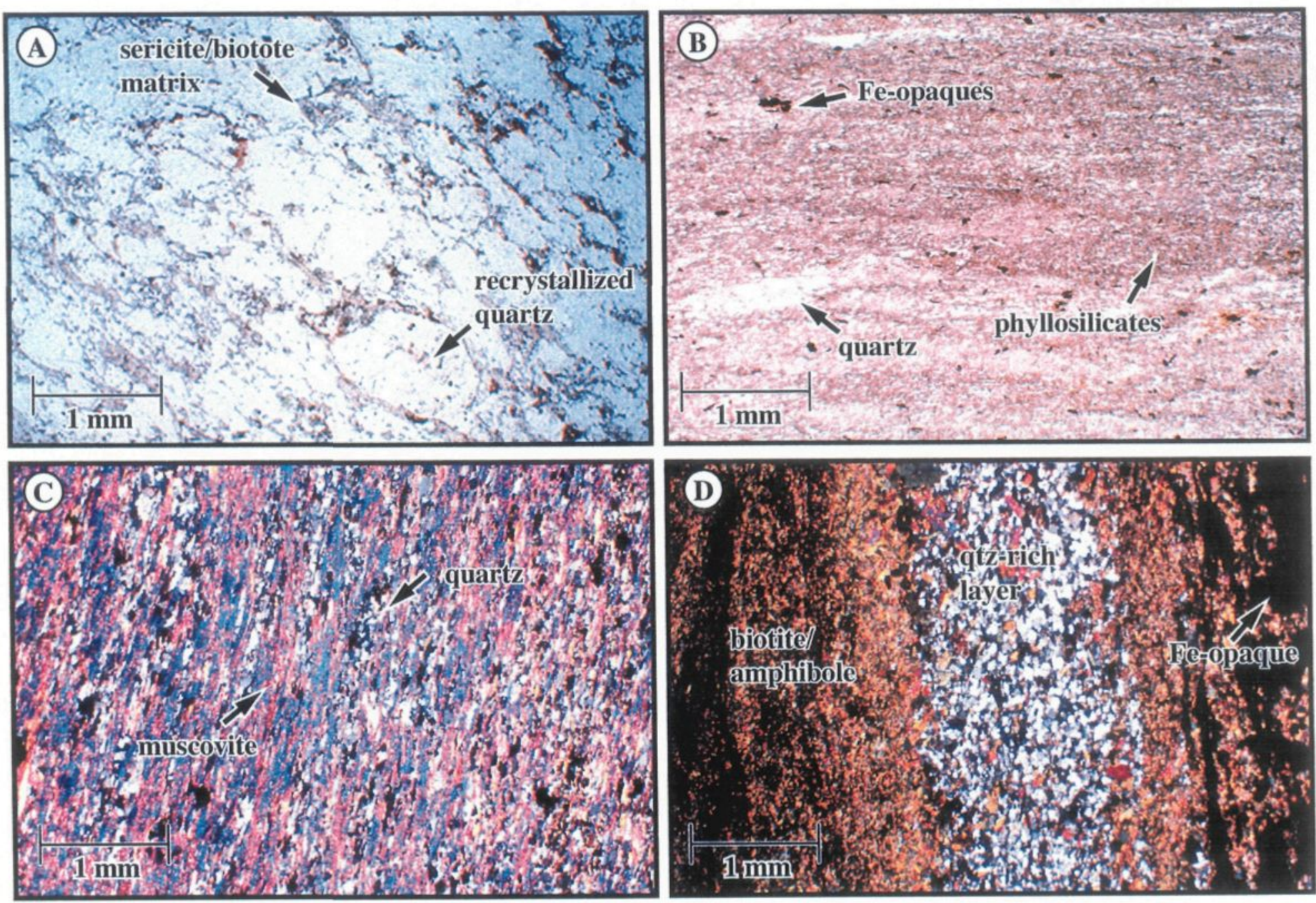

Plate 2.9 
samples. All samples have been silicified and two thin sections (from location C) reveal carbonate cement and/or calcite infilling post-depositional fractures.

\subsubsection{Siltstone-Sandstone Lithofacies}

Seventeen thin sections from siltstone beds of the SiSL are mainly composed of siltsized particles (0.01-0.06 mm) with some fine-grained sand-size material (up to $0.2 \mathrm{~mm}$ ). Schistosity and crenulation cleavages are well-preserved in the fine-grained rocks. The mineralogy consists of biotite, muscovite and lesser amounts of chlorite and amphibole (hornblende and/or actinolite-tremolite). These metamorphic minerals are commonly aligned parallel to schistosity, defining foliation and possess acicular and bladed crystal forms (Plate $2.9 \mathrm{~B} \& \mathrm{C}$ ). Slightly coarser $(<0.2 \mathrm{~mm})$ subangular to subrounded quartz grains are also present and dispersed throughout the mass of phyllosilicates. With the exception of one sample from study area A, feldspars are absent and the heavy mineral content is less than 3\%. The SiSL samples show textures characteristic of pelitic rocks with metamorphic grades ranging from upper greenschist to lower amphibolite. Study area $\mathrm{A}$, in the Beniah Lake fault zone reveals the highest metamorphic grade within which pelitic mica-schists containing local garnetiferous layers are found. Individual garnet porphyroblasts range from $0.5 \mathrm{~mm}$ to $2 \mathrm{~cm}$.

The iron-formation sublithofacies (IFSL) contains alternating polycrystalline quartzrich (1-9 $\mathrm{mm}$ thick) and amphibole/biotite-rich layers (2-12 mm thick) (Plate 2.9 D). The quartzose material has been highly recrystallized and original grain size is undeterminable. Iron-opaque minerals are generally restricted to the dark bands containing amphibole (hornblende?) and biotite (with lesser chlorite and muscovite). The magnetic properties vary and the more magnetic samples generally contain the most abundant Fe-opaques (up to $20 \%$ of a given thin section and $\leq 45 \%$ of a given amphibole-rich layer). 


\subsection{Interpretation of Petrography}

Table 2.2 displays the results of point-counting from 16 QAL samples and eight samples from the SaSL. Polycrystalline quartz predominates the overall framework mineralogy, muscovite is the most common mica and the total percentage of mica increases from the QAL to the SaSL. Only two samples from the QAL (collected from location C-1) reveal the presence of feldspars, both of which constitute less than $1 \%$ of the total volumetric mineralogy. Recalculating the percentage of the samples to include only quartz, feldspars and lithic fragments reveals that both lithofacies contained $100 \%$ quartz in all but two cases, where quartz represents 99 and $99.5 \%$. Based on the definition proposed by Williams et al. (1982) and using the Quartz-Feldspar-Lithic ternary diagram of Folk (1980), all 24 samples from the QAL and SaSL are quartz-arenites (Figure 2.13). The abundance of polycrystalline quartz and sutured boundaries is indicative of deformation and recrystallization resulting from metamorphism (Basu et al. 1975).

The abundance of micaceous material in the SaSL samples and some QAL samples is unclear. It is possible that primary feldspar grains (mostly K-feldspar) were chemically and physically broken down to clays and subsequently replaced by muscovite through metamorphism. In such an event, the initial mineralogical maturity of these rocks would have been lower than that displayed by the samples at present. It is also possible that the original matrix was kaolinite-rich and was diagenetically transformed to illite, thus forming abundant white mica.

The mineral assemblages of the SiSL, including biotite, chlorite and garnet, are all metamorphic, however they imply that the primary mineralogy of these rocks was clayey material derived from a mafic to ultramafic source. Subsequent metamorphism and tectonic deformation after lithification led to the recrystallization of these phyllosilicates and the nucleation of garnet porphyroblasts. 


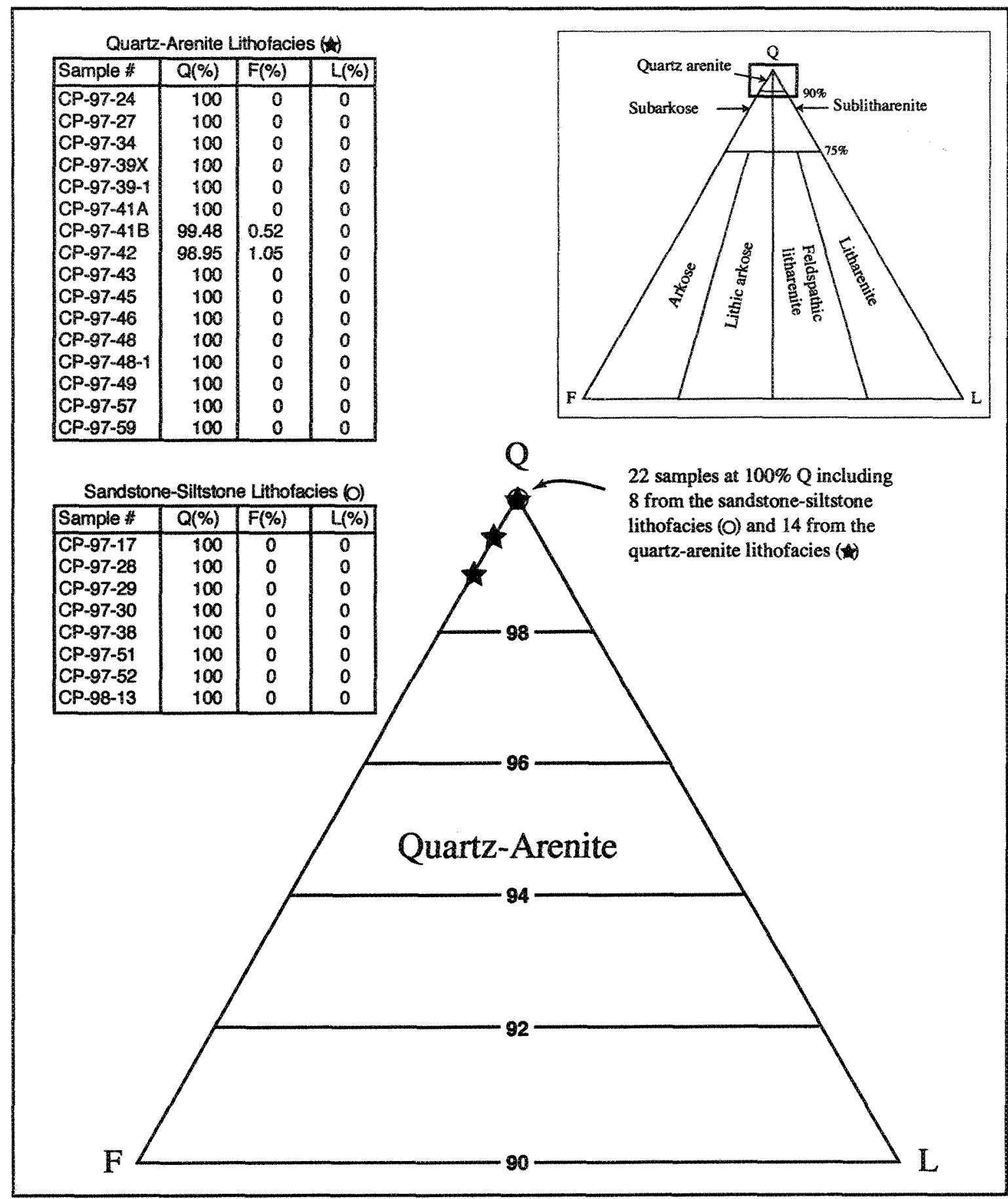

Figure 2.13. Point-counting results of the quartz-arenite and sandstone-siltstone lithofacies plotted on the

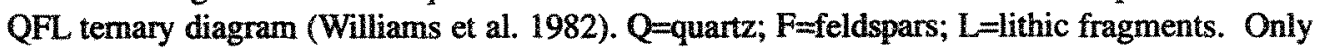
framework grains are used for classification, hence the matrix has been excluded. See Table 2.1. for further details. 


\section{CHAPTER 3}

\section{BELL LAKE FORMATION}

\subsection{Introduction}

The basement and supracrustal rocks of the Bell Lake area, contemporaneous with the Beniah Lake rocks are located approximately $42 \mathrm{~km}$ north of Yellowknife. A detailed sedimentary facies study was conducted to compare these rocks with the Beniah Formation. The Bell Lake area contains a volcano-sedimentary package of medium- to coarse-grained quartz-arenite, fine- to medium-grained sandstone, siltstone, minor felsic tuffs and ironformation. The general stratigraphy and geochronology of the Bell lake rocks have been described by Isachsen \& Bowring (1997) as well as by Bleeker et al. 1999 (Figure 3.1), however a detailed sedimentary facies analysis is lacking.

\subsection{Local Geology}

The Bell Lake Formation overlies the Anton Complex, a $>2.93 \mathrm{Ga}$ sialic basement containing a mix of highly deformed tonalite to granodiorite gneiss (Isachsen \& Bowring 1997). The nature of the contact between the basement and the Bell Lake Formation is enigmatic and has been considered either an intrusive contact or a nonconformity. Overlying the Bell Lake Formation is a thick (up to $2 \mathrm{~km}$ ) sequence of subaqueous tholeiitic basalts, characterized by massive, pillowed and brecciated flows (Jackson 1996). Depositional contacts between the Bell Lake Formation and the overlying volcanic rocks are absent, thus making stratigraphic correlations difficult. The volcanic rocks have been considered part of the ca. $2722 \mathrm{Ma}$ (Isachsen \& Bowring 1997) Chan Formation, which is 


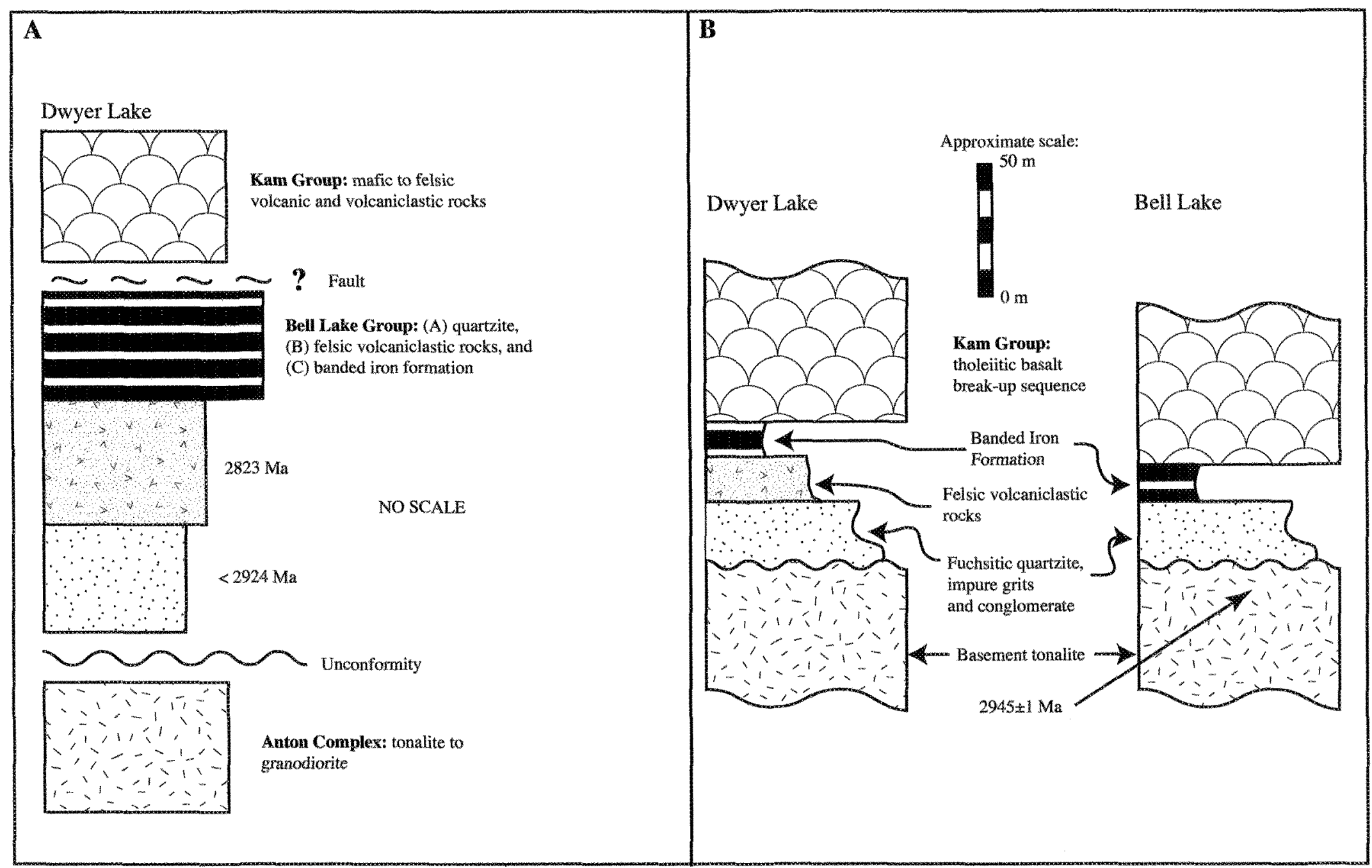

Figure 3.1. Stratigraphic columns illustrating the general stratigraphy of the Bell Lake group/formation described by A) Isachsen and Bowring (1997) and B) Bleeker et al. (1999). 
the basal formation of the Kam Group. A lithological map illustrating these various rocktypes of the Bell Lake Formation is shown in Figure 3.2.

The metamorphic grade in the Bell Lake area is upper greenschist to lower amphibolite with an increase in grade from east to west (Jackson 1996). The presence of a major $\mathrm{N}$-trending fault zone, possibly a splay from the Hay-Duck fault, has significantly influenced primary textures and structures. The principal schistosity is parallel to the steeply-dipping bedding planes $\left(>70^{\circ}\right)$ and varies $\pm 20^{\circ}$ both east and west of north. Primary sedimentary structures are difficult to discern and may have been overprinted during periods of intense deformation along the fault zone, however, cross-bedding is preserved locally. Quartz vein boudinage with pinch and swell structures support local high degrees of deformation.

\subsection{Lithofacies Distinction}

The Bell Lake Formation contains three major lithofacies including: 1) quartz-arenite, 2) sandstone-siltstone and 3) iron-formation lithofacies. A general stratigraphic section of the Bell Lake Formation and corresponding lithofacies is illustrated in Figure 3.3. The majority of exposed outcrops are located on the eastern shore of Bell Lake, generally less than tens of metres from the shoreline (Figure 3.2). The thickness of the Bell Lake Formation ranges from approximately $70 \mathrm{~m}$ near the south end to less than $30 \mathrm{~m}$ in the north and is continuously disrupted by $0.5-15 \mathrm{~m}$-thick gabbroic dykes/sills.

\subsubsection{Quartz-Arenite Lithofacies}

The 0.5-12 m-thick quartz-arenite lithofacies $(Q A L)$ comprises $\sim 31 \%$ of the Bell Lake Formation and is composed of medium- to very coarse-grained, well-sorted sandstone. Composite beds (0.25-1.5 $\mathrm{m}$ thick) are predominantly tabular shaped and contain parallel laminae with shallow-dipping cross-laminae and undulating/wavy bedforms. Tabular beds are often laterally continuous for tens of metres. Ten to $40 \mathrm{~cm}$ thick planar beds with parallel laminae (generally $<1 \mathrm{~mm}$ thick) are the predominant sedimentary structures (Plate $3.1 \mathrm{~A}$ ). Subordinate low-angle cross-beds are generally $<10$ 


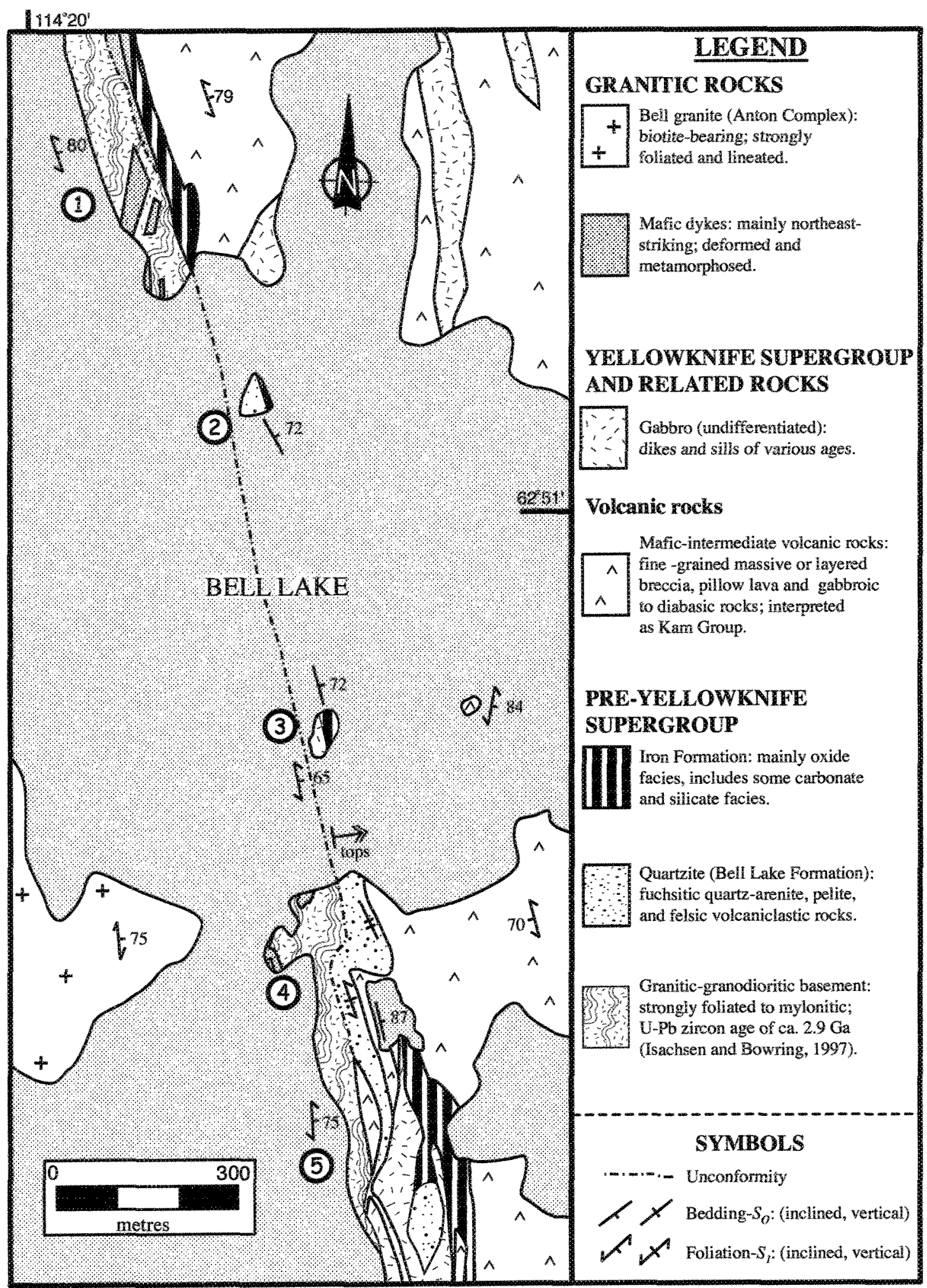

Figure 3.2. Lithological map of the Bell Lake area. Adapted from Jackson et al. 1998. The circled numbers indicate the location of composite stratigraphic sections (see Figure 3.3). 


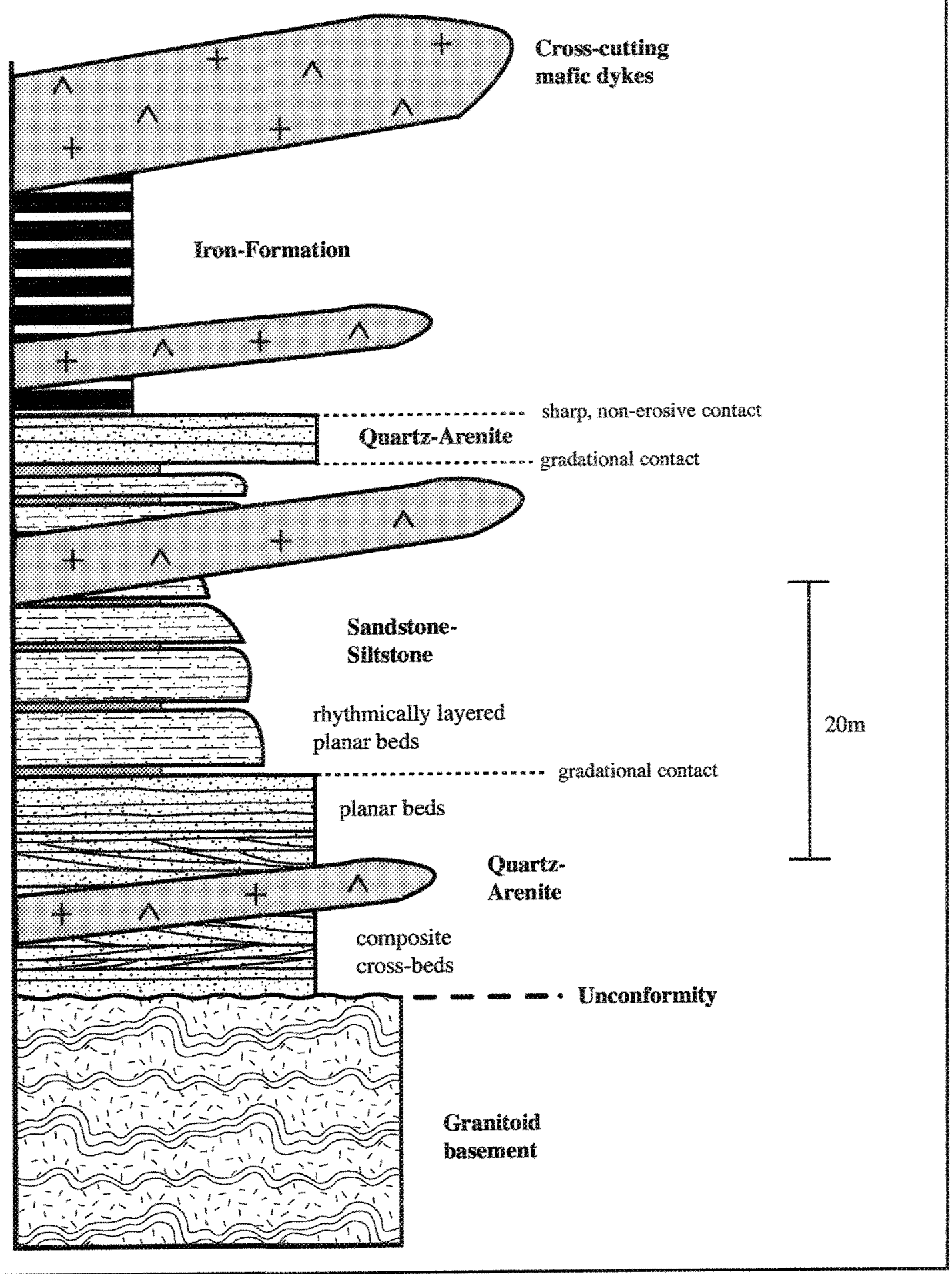

Figure 3.3. General, composite stratigraphic section of the Bell Lake Formation and corresponding sedimentary lithofacies. 
Plate 3.1 (A) Close-up of fuchsitic quartz-arenite containing predominantly planar parallel laminations. Pencil is $14 \mathrm{~cm}$ long and points in the younging direction (east).

Plate 3.1 (B) Fuchsite layers in the thinly bedded quartz-arenite reveals cross-bedding structures that indicate a younging direction towards the east, as indicated by the pencil ( $14 \mathrm{~cm}$ long).

Plate 3.1 (C) Outcrop view of the volcaniclastic sandstone from the SaSL in sharp, nonerosive contact with the overlying iron-formation lithofacies that has been subsequently intruded by a gabbro sill. The hammer is $30 \mathrm{~cm}$ long and the arrow points to the younging direction. 

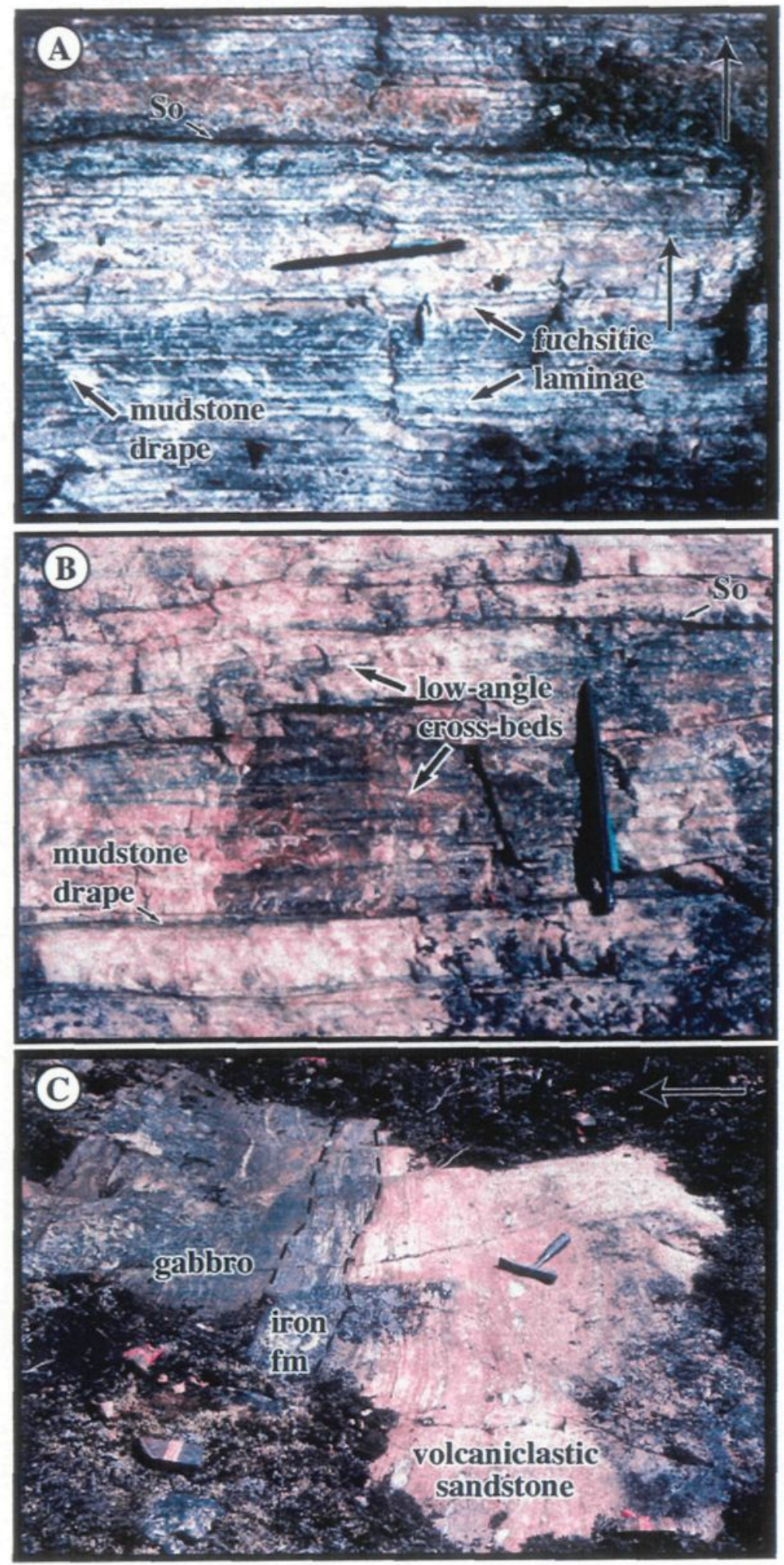

Plate 3.1 
$\mathrm{cm}$ thick and indicate an east-younging direction (Plate 3.1 B). Tabular beds and crosslaminae are commonly capped by $\mathrm{mm}$ - to $\mathrm{cm}$-thick mudstone drapes. The mineralogy of the QAL is extremely quartz-rich and is composed of medium-to coarse-grained quartz, muscovite and subordinate feldspar. The QAL also contains mm-size, subrounded detrital chromite grains that are often enveloped by seams of green mica formed by reaction between chromite and feldspar grains during shearing and metamorphism (Bleeker et al. 1999). Locally, the quartz-arenite beds are intercalated with fine- to medium- grained sandstones ( $<30 \mathrm{~cm}$ thick) that are generally dark, poorly to moderately sorted and contain laminae parallel to the north-trending fault zone.

The QAL directly overlies the Anton Basement Complex, which can be observed in two locations on the southern and central area of Bell Lake (Figure 3.2). The protomylonitic basement rock is composed of coarse-grained quartz phenocrysts and medium- to coarse-grained plagioclase with smaller potassium feldspars, in a groundmass of finer quartzofeldspathic material and phyllosilicates. Bedding planes of the overlying sedimentary rocks are generally parallel and conform to the upper bounding surface of the basement rock (Plate 3.2 A and B). One outcrop shows onlapping of the quartz-arenite beds over the basement rock and reflects minor variations in the topography of the original depositional surface (Plate 3.2 C). In the north, the contact is offset by a series of smallscale faults.

The abundance of low-angle cross-laminae and planar beds in the QAL are characteristic of sedimentary processes from the lower to middle flow regime, consistent with sheet sandstones (Walker \& Plint 1996). Small-scale cross-beds correspond to lunate megaripples (Reineck \& Singh 1980). Millimetre-thick mica-rich laminae on and between the coarser-grained beds are indicative of short periods of low-energy conditions, similar to those produced during the waning stages of tidal flood-ebb cycles (Dalrymple 1992).

\subsubsection{Sandstone-Siltstone Lithofacies}

The sandstone-siltstone lithofacies (SaSL) comprises $\sim 29 \%$ of the Bell Lake Formation, varying in thickness from 1-12 $\mathrm{m}$ and is characterized by intercalated medium- - 
Plate 3.2 (A) Sharp contact between the quartz-rich granitoid basement and quartzarenite. The trace of the contact is parallel to the bedding planes of the overlying sedimentary rocks. The hammer is $30 \mathrm{~cm}$ long and the arrow indicates a younging direction to the east.

Plate 3.2 (B) Close-up of the contact between the basement (bottom) and thinly bedded quartz-arenite (top). Preservation of small-scale cross-beds and clay drapes in the sedimentary rocks suggests that the quartz-arenites have not undergone the same degree of deformation as the protomylonitic basement rocks. Pencil is $14 \mathrm{~cm}$ long and points to tops.

Plate 3.2 (C) Close-up of the contact showing onlapping structures of the quartz-arenite over the basement in response to a slight change in topography. Pencil is $14 \mathrm{~cm}$ long and points to tops. 

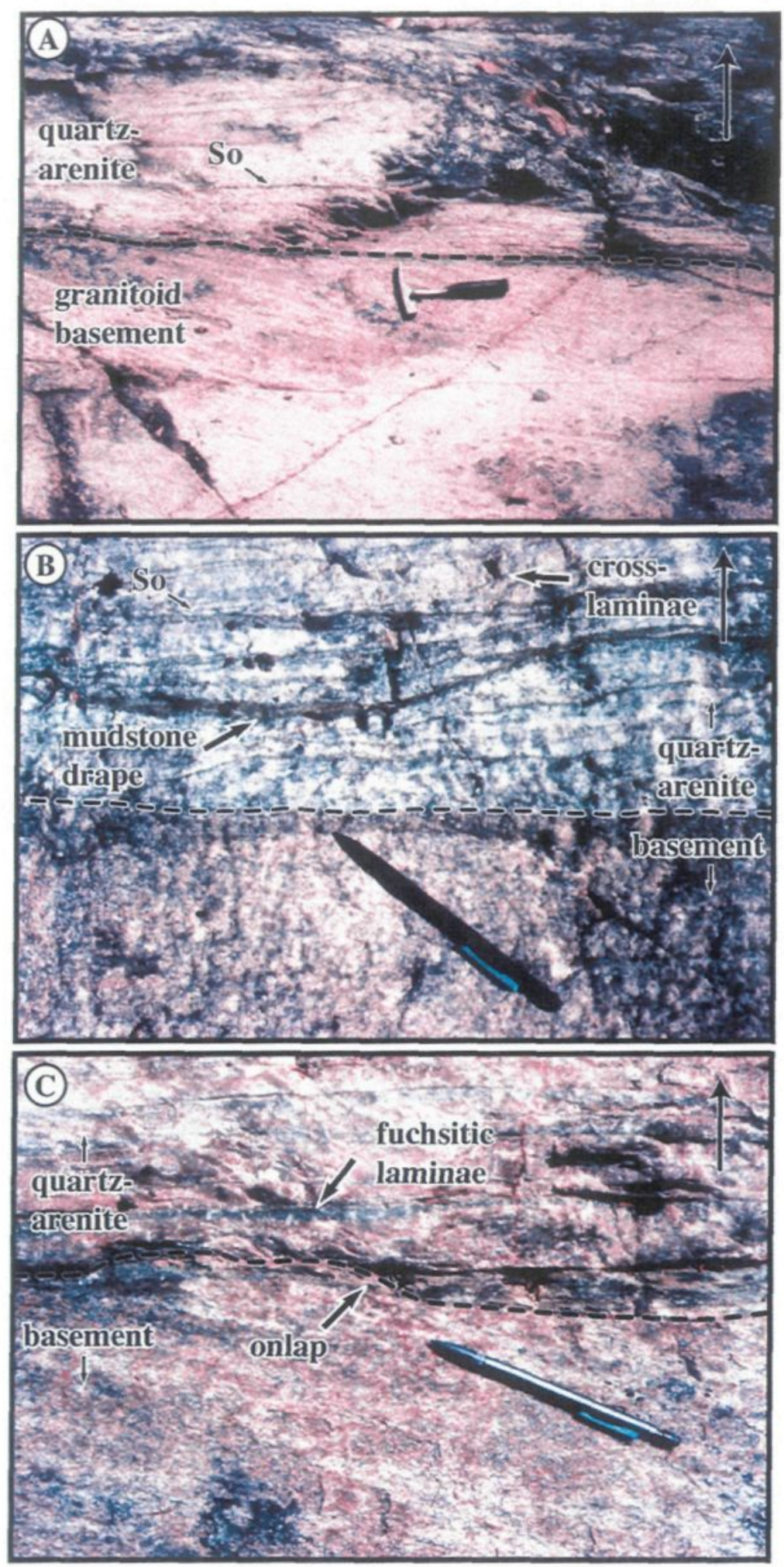

Plate 3.2 
grained sandstone and siltstone. The alternation of 25-75 cm-thick sandstone and 5-10 cmthick siltstone layers is regular, giving the lithofacies a "striped" appearance. Locally, the siltstone beds contain metamorphic garnet-rich layers with individual garnet porphyroblasts as large as $1 \mathrm{~cm}$. The predominant sedimentary structures in the sandstone beds are planar, parallel laminae with local graded bedding, although many are massive. Locally, the SaSL contains coarser-grained interbeds, generally less than $0.5 \mathrm{~m}$ thick that are characteristic of the QAL sandstones. All beds in the SaSL can be traced laterally for several metres, where outcrop exposure permits.

Planar bedding and parallel laminae are either formed by suspension deposition in a milieu of low-energy, under. low flow strength conditions (Prothero \& Schwab 1996) or by storm wave reworking of earlier cross-beds (Walker \& Plint 1996). The latter gains support based on the presence of graded beds that were probably produced during the waning of storm-generated flows. Interbedded sandstone with siltstone indicates alternating flowenergy conditions induced either by tides or storms. Coarser sands are deposited during the advancing and receding of tides where current is strongest, while at low water and high water between tides, there is relatively little flow and finer sediments are deposited (Homewood \& Allen 1981). However, in the case of storms, silty layers may have been deposited under calm conditions, alternating with regular influxes of sand giving rise to the coarser-grained layers (Strachan 1986). Based on the presence of other prominent sedimentary structures such as graded bedding, low-angle cross-bedding and the presence of mudstone drapes; a combination of the two is envisaged.

Outcrops showing an altemation between the QAL and SaSL might reflect a change in sediment supply or variations in flow-energy conditions, allowing for the deposition of fine- and coarse-grained material. The moderately- to well-sorted, coarse-grained quartzarenite beds reflect an abundance of grain abrasion resulting from high flow-energy conditions, whereas the hydraulic regime for the thythmic sandstone-siltstone beds was probably lower, resulting in the deposition of fine-grained sand and more abundant silt-size material. A felsic to intermediate volcaniclastic sub unit, located at the top of the sandstone-siltstone lithofacies, ranges in thickness from 0.5-3 $\mathrm{m}$ (Plate $3.1 \mathrm{C}$ ). The 
volcaniclastic sandstone is fine- to medium-grained and is characterized by thin, fine parallel laminae. These rocks appear less mineralogically mature than the rest of the SaSL and QAL.

\subsubsection{Iron-Formation Lithofacies}

The 0.5-30 m-thick iron-formation lithofacies (IFL) occupies $40 \%$ of the Bell Lake Formation. It is characterized by alternating bands of fine-grained siliceous material and darker bands of silt-size material (Plate 3.3 A and B). There are two main occurrences of the IFL, with one located near the stratigraphic top of the Bell Lake Formation and the other between the thick sequence of mafic volcanic flows (up-section). Rare isolated beds, $<1 \mathrm{~cm}$ thick, are interstratified with the SaSL, although contact relationships are obscured by mafic dykes. Plate $3.3 \mathrm{C}$ depicts the sharp contact between the SaSL and overlying IFL, which has been disrupted by gabbroic dykes/sills.

Beds contain parallel, planar- to wavy-laminae and are restricted to $1-3 \mathrm{~cm}$ in thickness. A calm setting is envisaged, whereby suspension deposition is the predominant sedimentary process. The abundance of parallel laminae and fine-grained material reveals that these rocks were deposited on a relatively flat surface, with little topographic relief. The characteristic banding of this lithofacies shows strikingly similar characteristics to rhythmically layered couplets related to tidal periodicities (Miller \& Eriksson 1997; Adkins \& Eriksson 1998). Tidalites of comparable thickness and features from the Horseshoe Canyon, Alberta (Nio \& Yang 1991) are an example of this type of rhythmic deposition. These rhythmites contain a predominance of sandstone at the base and siltstone near the top, as do the sandstone-siltstone and iron-formation lithofacies at Bell Lake. Plate 3.4 shows the similarity between tidal rhythmites from the Cretaceous Horseshoe Canyon (A) and the Archean Bell Lake Formation (B).

\subsection{Petrography of the Lithofacies}

In thin section, the QAL reveals abundant polycrystalline quartz with muscovite surrounding the grains. In addition, minor feldspars, including untwinned and twinned 
Plate 3.3 (A) Iron-formation lithofacies at Bell Lake containing alternating bands of fine-grained siliceous sandstone and very fine-grained Fe-oxide and siltstone/clay-rich material. Pen is $13.5 \mathrm{~cm}$ and points to the east younging direction.

Plate 3.3 (B) Close-up of the iron-formation revealing primary sedimentary structures of undulating laminae between siliceous and Fe-rich layers. Pen is 13.5 $\mathrm{cm}$ and points to the east younging direction.

Plate 3.3 (C) Transition between the sandstone-siltstone lithofacies (SaSL) and the overlying iron-formation (IFL) intruded by a gabbro sill. Pencil is $14 \mathrm{~cm}$ long and arrow points east, indicating tops. 

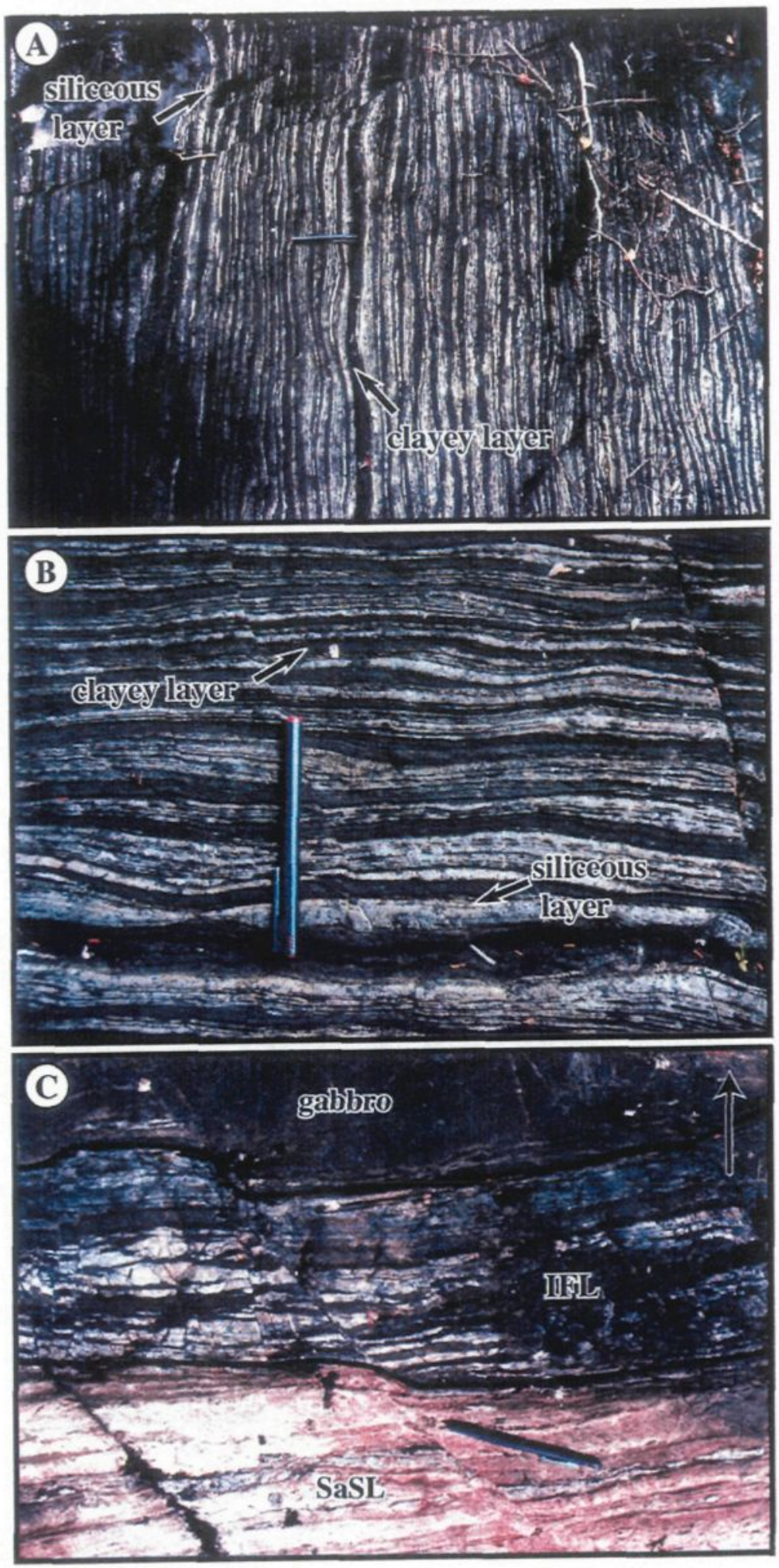

Plate 3.3 
Plate 3.4 (A) Example of tidal rhythmite from Horseshoe Canyon, Alberta. Cretaceous (Nio and Yang 1991). Rock consists of alternating bands of cm-thick, fine-grained sandstone and siltstone/mudstone.

Plate 3.4 (B) Iron-formation from the Archean Bell Lake Formation showing striking similarity to the tidal rhythmite from (A). The pen is $13.5 \mathrm{~cm}$ long and points in the younging direction. 

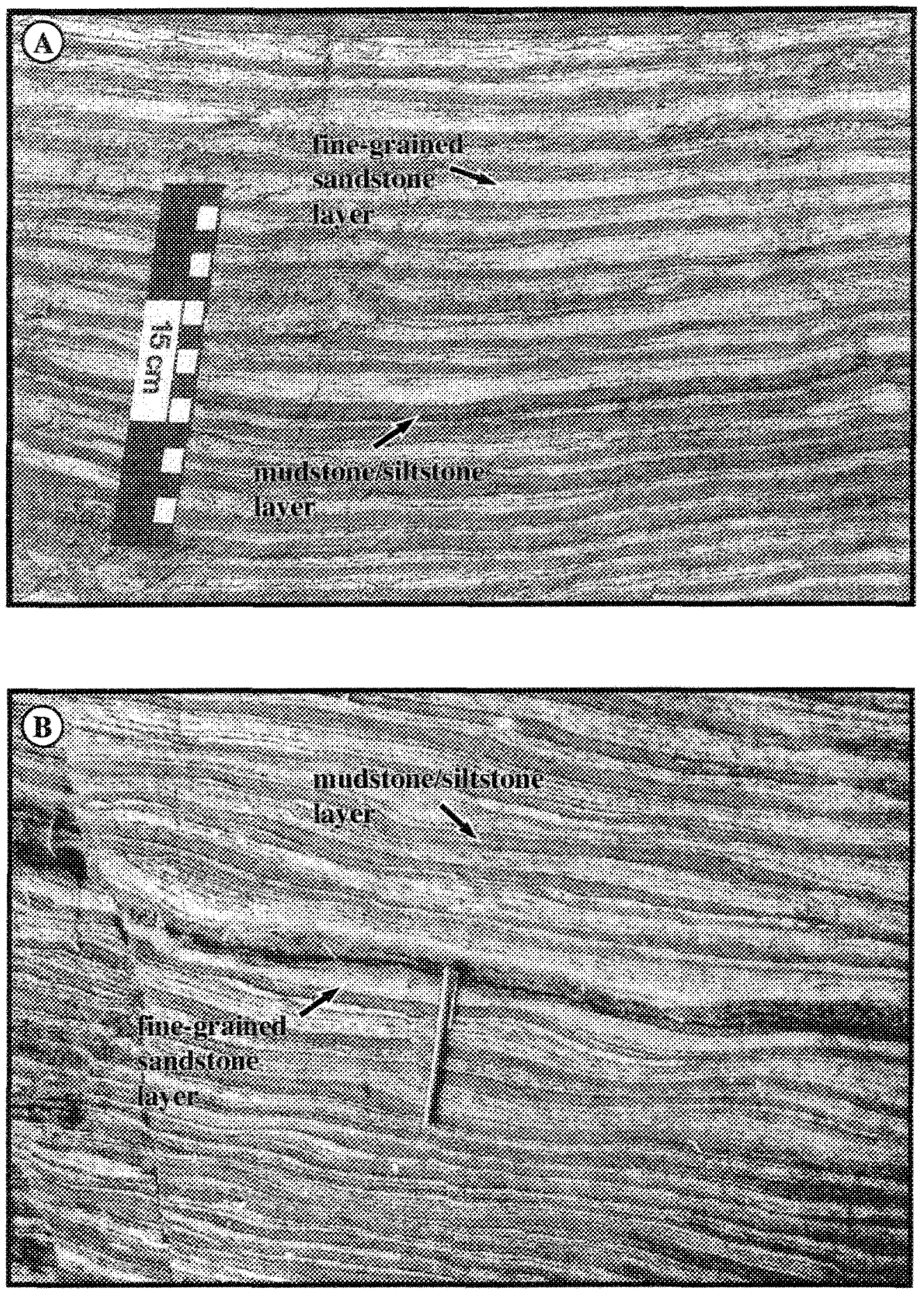

Plate 3.4 
plagioclase and microcline, comprise $0-9 \%$ of any thin section. Plagioclase grains are generally larger than potassium feldspars. The sandstones are poorly- to moderately-sorted with a moderate to high sphericity. Lithic fragments are rare, constituting a maximum of $1.4 \%$ and are identified as plutonic, derived from the underlying basement. The heavy mineral suite, comprising less than $1 \%$, is restricted to subrounded grains of chromite (0.05-2 $\mathrm{mm})$ and rare subrounded zircons. Prior to recalculation of quartz, feldspars and rock fragments, the modal percentage of mica, based on point-counting, is particularly high, ranging from $9-25 \%$.

In thin section, sandstone layers of the SaSL contain a mix of polycrystalline quartz $(0.05-1 \mathrm{~mm})$ in a matrix of biotite, chlorite and muscovite (in order of abundance). Quartz grains are generally subangular to subrounded, although high degrees of recrystallization mask primary textures significantly. Feldspars are accessory and all phyllosilicates are aligned parallel to both bedding and the regional north-trending foliation. Siltstone layers are finer-grained and schistose, due to the abundance of micaceous material. Locally, cmthick bands of siltstone contain abundant garnet porphyroblasts, ranging from 0.1-0.8 $\mathrm{mm}$. Other metamorphic minerals include minor epidote and hornblende.

Microscopic characteristics of the IFL include mm- to cm-thick bands of amphibolerich material containing abundant magnetite, alternating with fine-grained siliceous layers. Amphibole bands also contain lesser biotite characterized by bird's eye extinction. Quartzrich layers are totally recrystallized and primary sedimentary textures have been obliterated.

\subsection{Stratigraphic Correlation of the Bell Lake Formation}

The correlation of five detailed stratigraphic columns, spanning approximately $2 \mathrm{~km}$ is illustrated in Figure 3.4. The stratigraphic columns demonstrate a lateral thinning of the overall formation from south to north, although this could be partially due to the abundance of intruding dykes and sills. Vertically, the lithofacies reveal a general upward-fining of grain size with coarse-grained quartz-arenite at the base and siltstone/iron-formation at the top. 


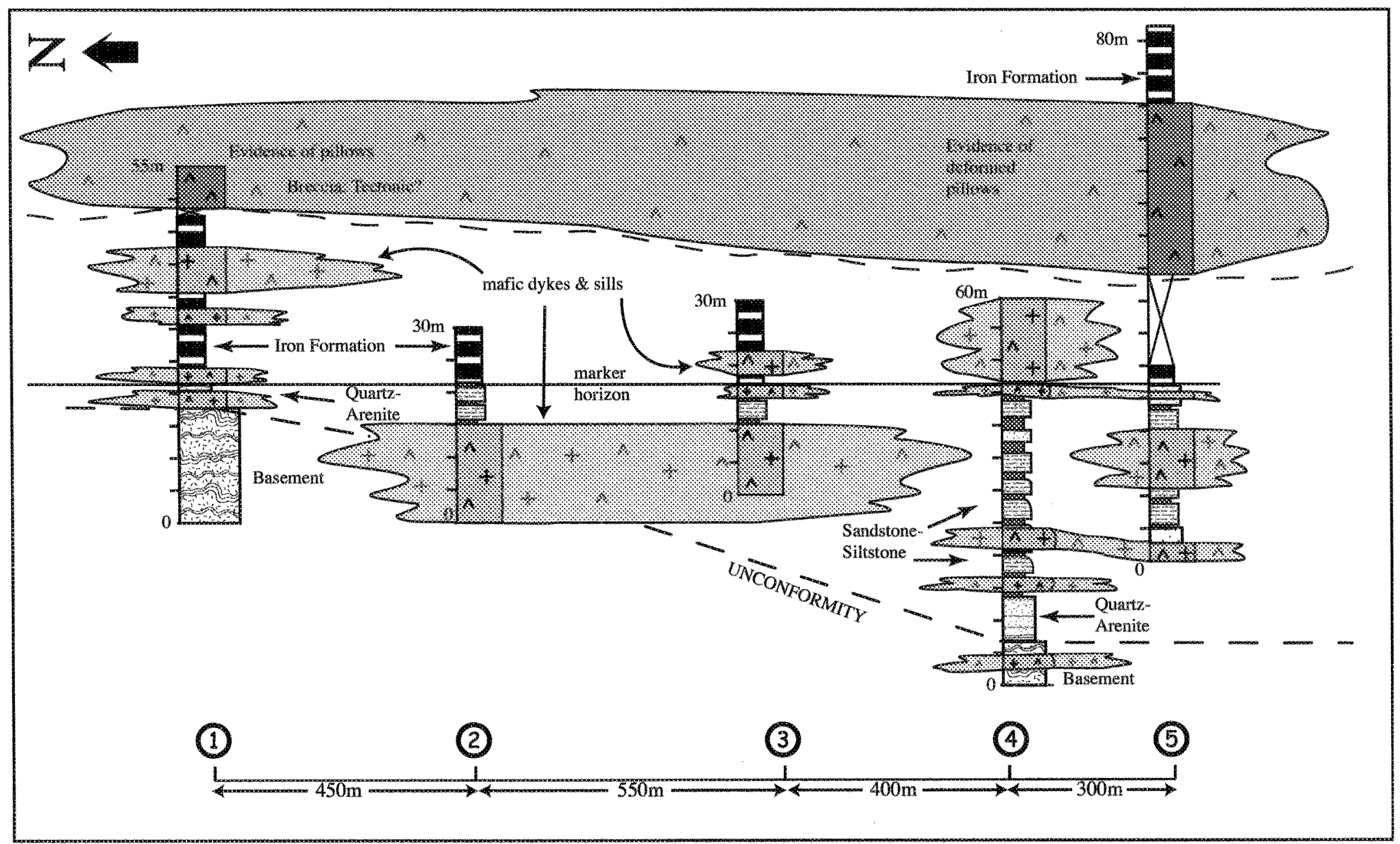

Figure 3.4. Stratigraphic correlation of the Bell Lake Formation including the underlying basement and overlying tholeitic flows (Kam Group equivalent?) the shaded areas between the stratigraphic columns represents correlated rock-types (e.g. mafic dykes and flows) The location of each composite stratigraphic section (1-5) can be found in Figure 3.1. 
The correlation of several stratigraphic sections reveals a distinct vertical and lateral trend of the lithofacies. The basal QAL is characterized by medium- to coarse-grained, tabular beds with small- and medium-scale cross-laminae and mm-thick drapes of green mica. The SaSL located in the central portion of the Bell Lake Formation is generally, finer-grained, less compositionally mature and contain sedimentary structures including planar, parallel laminae and local graded bedding. The upper portion of the Bell Lake Formation, with the thicker IFL, is fine-grained and is characterized by planar to wavy undulating parallel laminae. The iron-formation was chosen as a marker horizon because it is found in each of the stratigraphic sections and serves to delineate the upper stratigraphic lithofacies of the Bell Lake Formation.

\subsection{Basement and Cover Sequence Relationship}

Many authors suggest an unconformable, rather than intrusive contact between the granitic-gneissic basement and overlying quartz-arenites of the Bell Lake Formation (MacLachlan \& Helmstaedt 1993; Jackson 1996; Isachsen \& Bowring 1997; Bleeker et al. 1999), however, this relationship has never been appropriately documented. Both petrography and detailed mapping of the contact along strike will assist in determining the nature of this contact.

Figure 3.5 illustrates two detailed outcrop sketches revealing the inferred unconformable contact between the basement and overlying QAL from the south and north. Outcrop A shows the proto-mylonitic, well-foliated basement in sharp contact with the overlying tabular planar and locally cross-bedded quartz-arenite. The contact appears irregular, however this is a result of displacement along several small-scale faults. Outcrop $B$ illustrates the sharp flat contact between the basement and sedimentary rocks that is traceable over $>20$ metres. Younging direction of the quartz-arenites, in both cases, is to the east and is indicated by foreset laminae orientation of small-scale cross-beds. The location of samples and photographs are indicated.

Petrographic analyses, aided by feldspar staining techniques provide sound scientific support for an unconformity. Samples from the granitoid basement and the overlying 


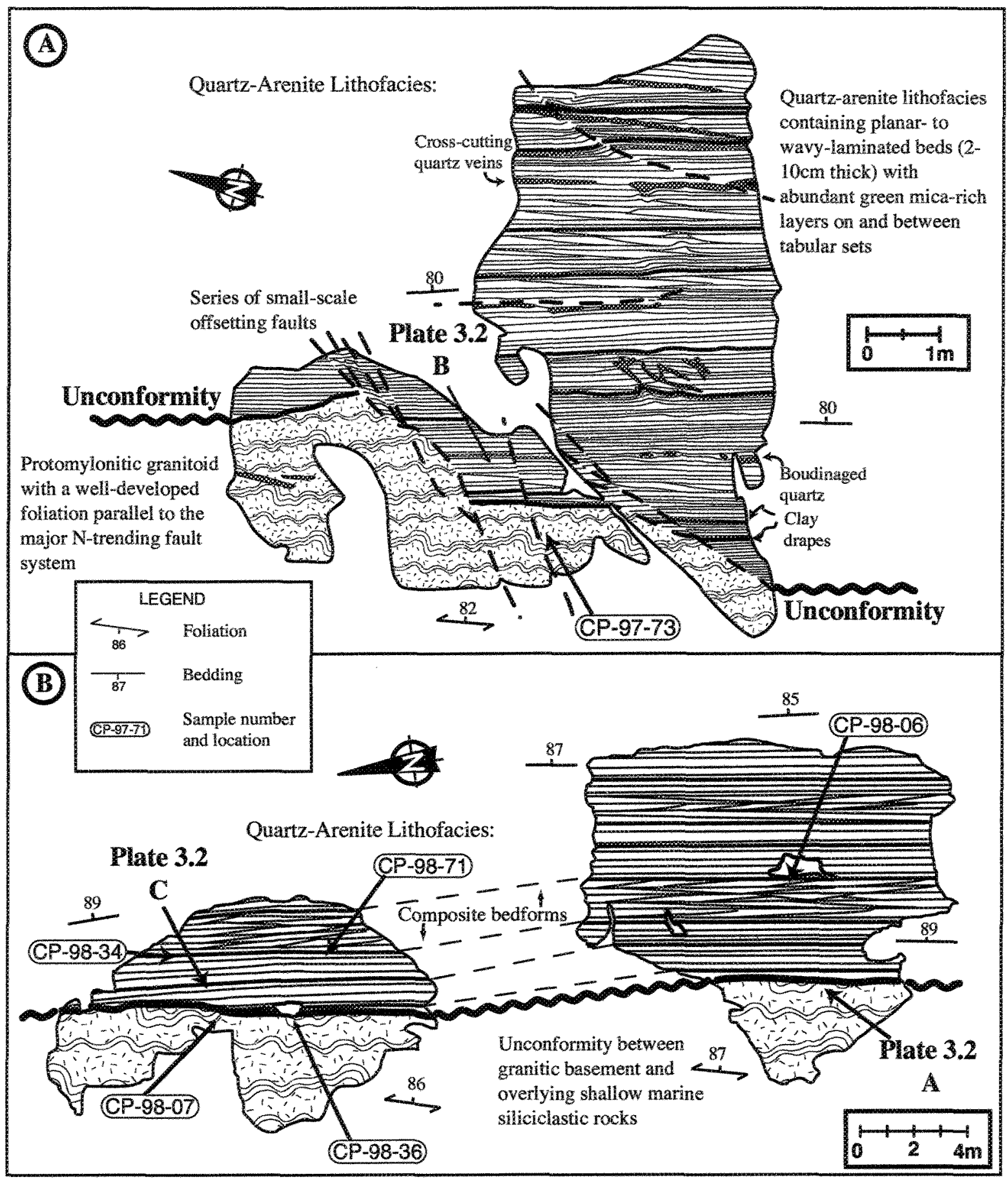

Figure 3.5. Contacts between granitoid basement and overlying quartz-arenite in the Bell Lake study area. The contact in Ais offset by a series of small-scale faults. The prominent sedimentary structures in the quartz-arenite lithofacies are planar, parallel laminations with low-angle cross-laminations. The sample locations used for point-counting are indicated (e.g. Location of photos are also shown (e.g. Plate $3.2 \mathrm{~A}$ ). 
quartz-arenite, both within close proximity to the contact, were cut for thin section and stained. Plate 3.5 shows both a stained quartz-arenite and granitoid. The yellow grains indicate the presence of potassium feldspars. Staining revealed the presence of potassium feldspars in both the basement rock and quartz-arenites with a slight greater abundance in the basement.

Thin sections of the basement rock reveal abundant polycrystalline quartz, massive and twinned plagioclase and microcline with muscovite between the crystals (Plate $3.6 \mathrm{~A}$ and B). The quartz-arenite samples also contain quartz, feldspars and muscovite, in greater abundance and with subrounded grains (Plate $3.6 \mathrm{C}$ ). Point-counting results of both the basement and overlying sedimentary rocks were conducted (Figure 3.6) and subsequently plotted in ternary diagrams. The three sedimentary samples contain $>90 \%$ quartz, $2-8 \%$ feldspars and $<1 \%$ lithic fragments, thus classifying them as quartz-arenites (Williams et al. 1982). The basement rocks contain $68-84 \%$ quartz, $12-22 \%$ plagioclase and $4-9.5 \%$ alkali feldspars. Based on the percentage of these mineral constituents, the basement rock is classified as a quartz-rich granitoid (Strekeisen 1979).

It is proposed that the comparative modal abundance of quartz and feldspars in both the granitic rocks and overlying quartz-arenites is the result of direct erosion of the basement and subsequent deposition on top. The increased amount of quartz and rounding of the grains in these sedimentary rocks is to be expected, considering the characteristic processes that occur in shallow marine settings, including both physical and chemical erosion as well as the overall net transport of grains. Based on these observations, it can be stated with certainty that the contact between the granitic-gneissic basement and the overlying Bell Lake Formation is unconformable and non-intrusive. 
Plate 3.5 (A) Stained quartz-arenite sample indicating the presence of potassium feldspar (yellow grains). The blue scale bar is $1 \mathrm{~cm}$.

Plate 3.5 (B) Hand sample of the quartz-rich basement rock. Yellow grains represent potassium feldspar revealed through staining techniques. The scale bar is $1 \mathrm{~cm}$. 

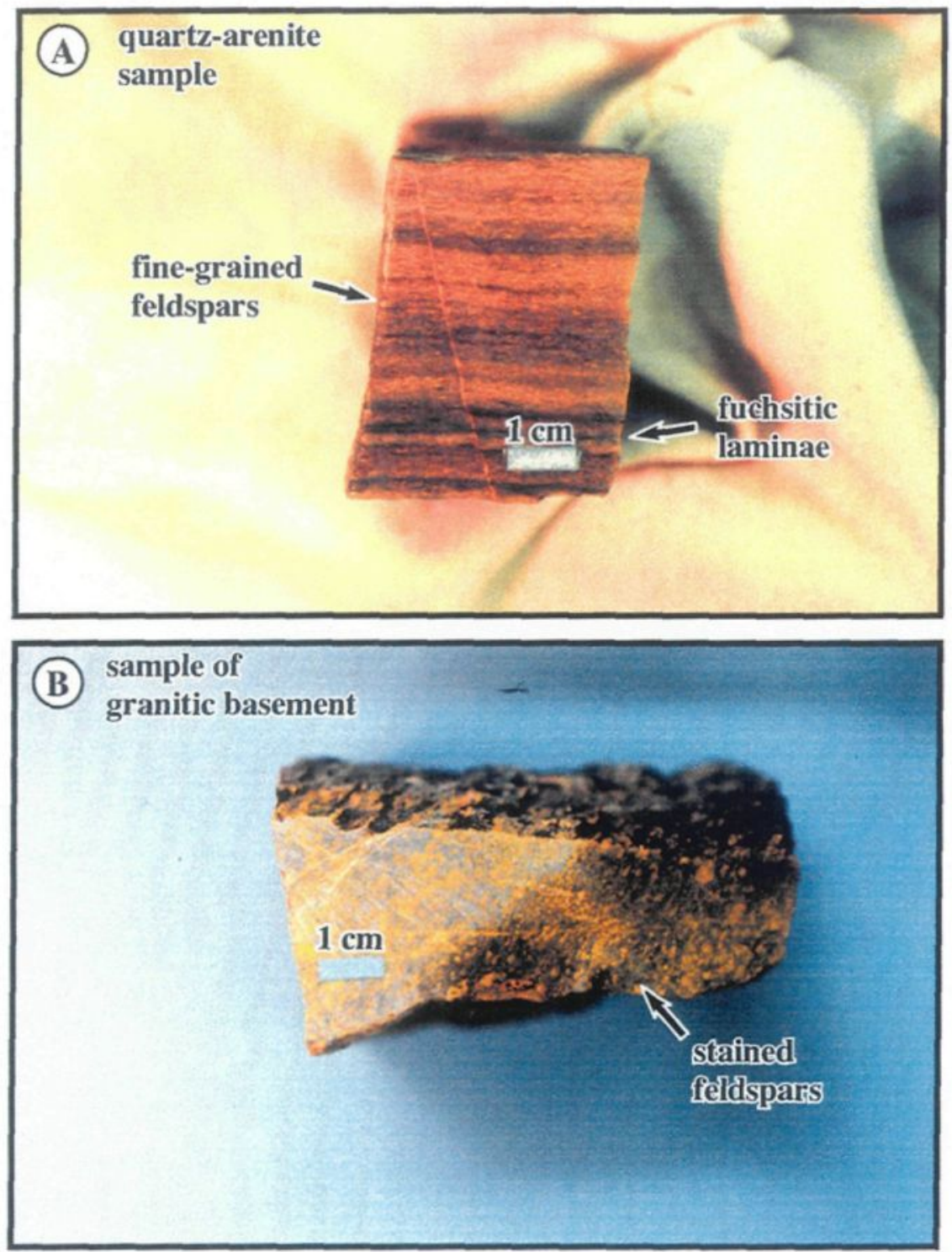

Plate 3.5 
Plate 3.6 (A) Thin-section of basement rock under plane-polarized light (CP-97-73). Crystals show relatively high degrees of strain and are surrounded by a groundmass of phyllosilicates. Field of view is $2.5 \mathrm{~mm}$.

Plate 3.6 (B) Same thin-section as (A) under crossed-polarized light. Plagioclase, microcline and quartz are readily identifiable and groundmass is composed primarily of muscovite. Field of view is $2.5 \mathrm{~mm}$.

Plate 3.6 (C) Quartz-arenite in thin-section under crossed-polarized light indicating a similar mineralogy to the basement rock, including small microcline grains, untwinned plagioclase and abundant quartz (CP-98-06). The matrix is quartz- and muscovite-rich. Field of view is $5 \mathrm{~mm}$. 

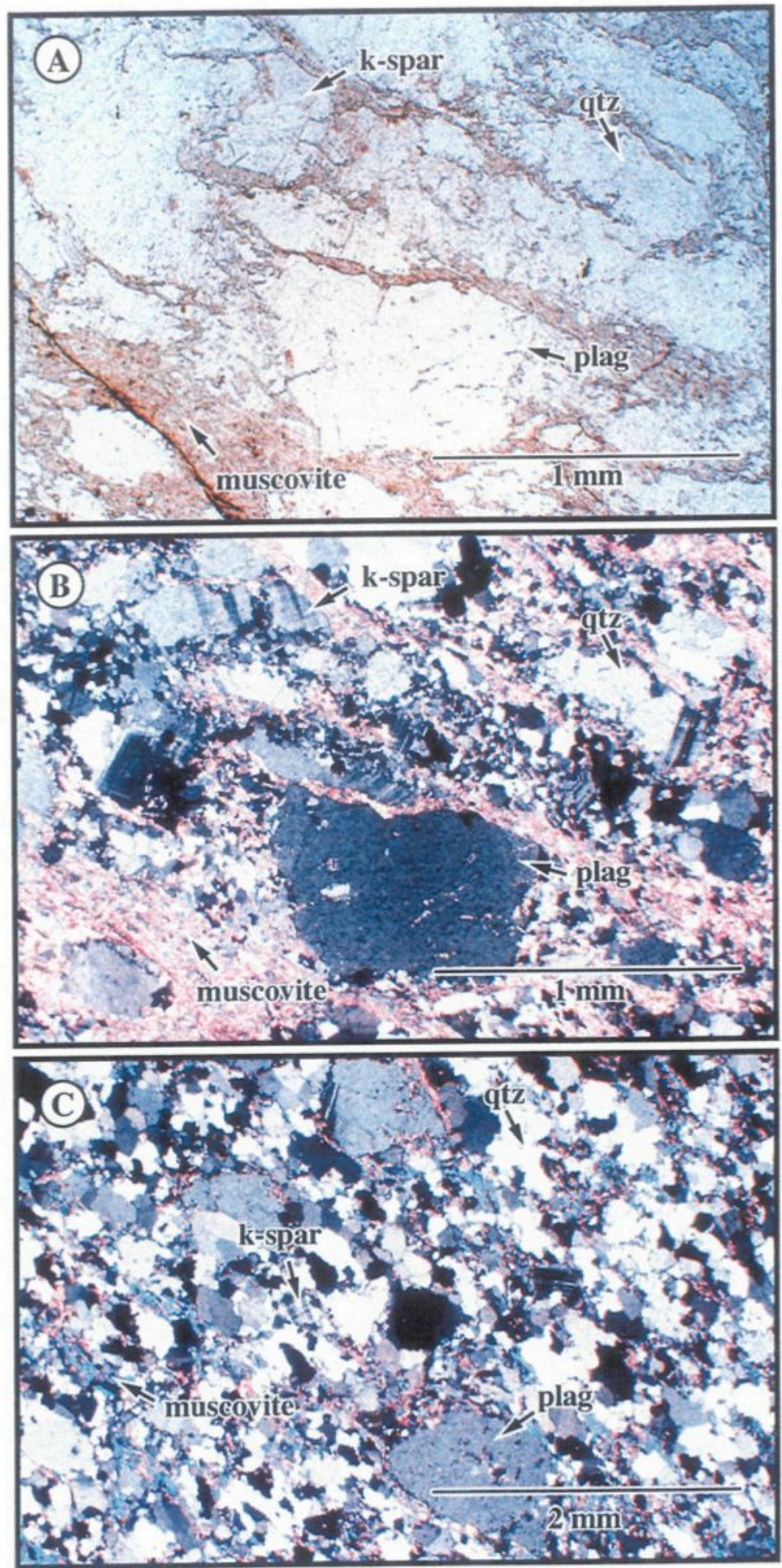

Plate 3.6 


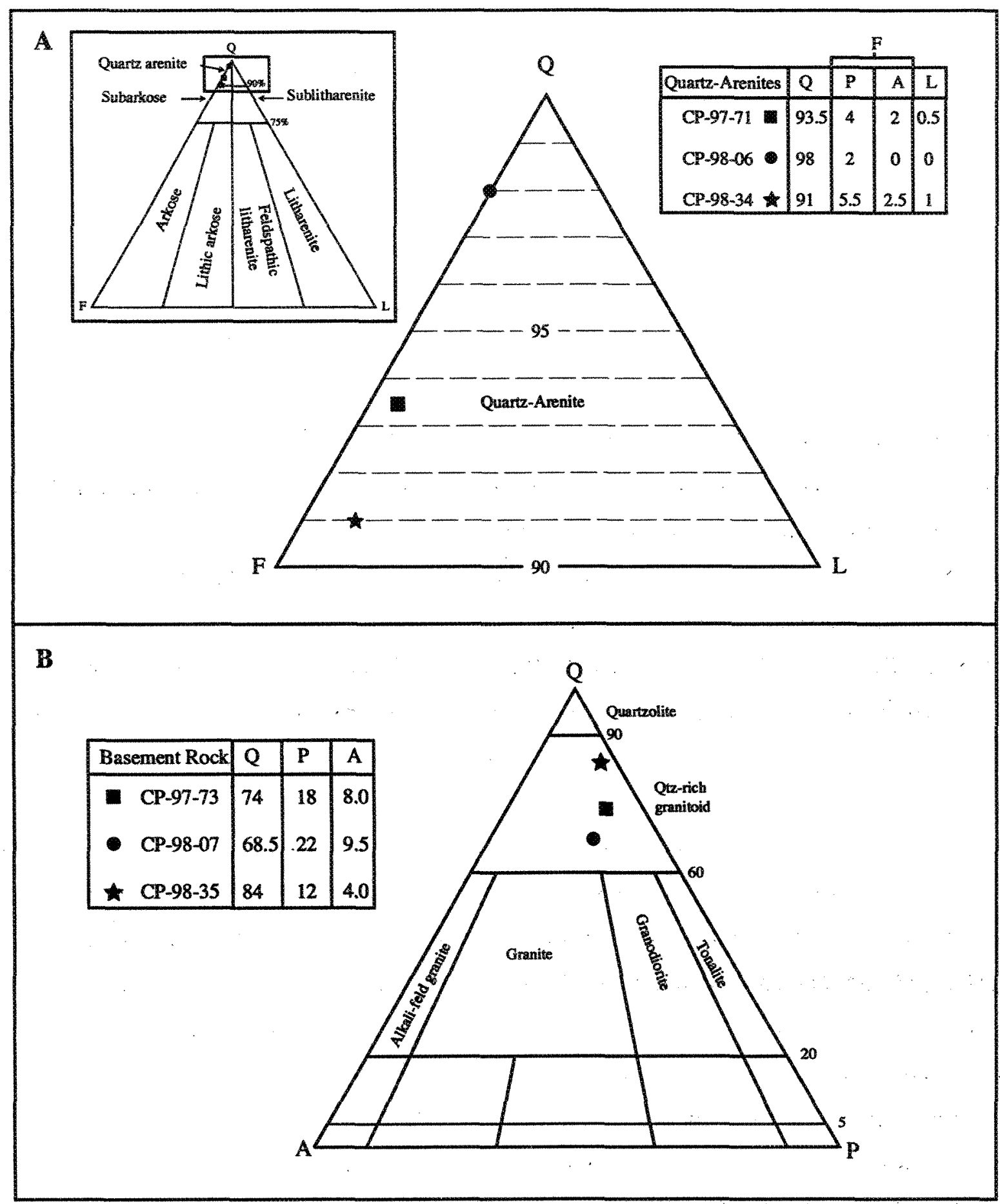

Figure 3.6. Ternary diagrams for the classification of A) sedimentary (modified from Folk 1980) and B) igneous rocks (Strekeisen 1979) from the Bell Lake Formation. $Q=$ quartz; $F=A+P$, where $F=$ total feldspars, $\mathrm{A}=$ alkali feldspars and $\mathrm{P}=$ plagioclase $; \mathrm{L}=$ lithic fragments. 


\section{CHAPTER 4}

\section{LITHOFACIES ANALYSIS}

\subsection{Introduction}

A standard, systematic approach is employed for facies modeling (Walker 1992). This includes: 1) the definition of lithofacies; 2) combining lithofacies into facies associations; 3) revealing facies successions; 4) comparing modern and ancient analogues to propose a facies model; 5) infer a depositional environment and 6) consider depositional system tracts. Defining the lithofacies was accomplished in Chapters 2 and 3, hence the purpose of Chapter 4 is to identify facies associations, interpret architectural elements, ascertain facies successions and consider an appropriate depositional setting for both the Beniah and Bell Lake formations.

\subsection{Association of Lithofacies: Beniah Formation}

A number of architectural elements are identifiable in the Beniah Formation, including tidal channels and levees, gravel bars and large-scale migrating sandwaves. The recognition of these 3-D elements is based on facies associations. For example, the transition from the WPSL to SaSL, illustrated in Figure 4.1, is abrupt and erosive. The SaSL is coarser-grained and contains medium- to large-scale cross-strata, while the WPSL contains mainly thinly-bedded siltstone with wavy to planar laminae and small-scale, lowangle cross-bedded sandstone interbeds. The detailed stratigraphic column in Figure $4.2 \mathrm{~A}$ displays the salient sedimentary structures of the SaSL and the WPSL. The abrupt transition between the two lithofacies is also depicted. The increase in grain size and crossbeds indicate that higher energy processes were responsible for depositing the SaSL than in 


\section{Location $\mathrm{C}-1$}

Tangential cross-bedded medium- to coarse-grained sandstone interbedded with parallel laminated siltstone. Orientation of foresets reflects multiple current directions

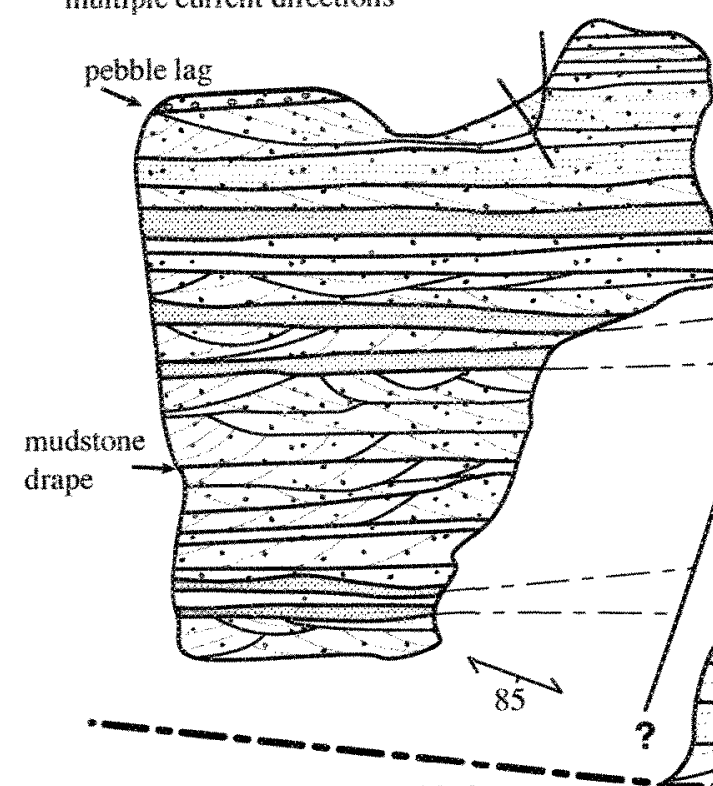

Contact between

mafic dyke and sedimentary rocks

\section{Wavy- to Planar-Bedded Siltstone Sublithofacies}

Predominantly planar- to wavylaminated siltstone to very finegrained sandstone interbedded with coarser-grained, planar bedded and cross-bedded sandstone
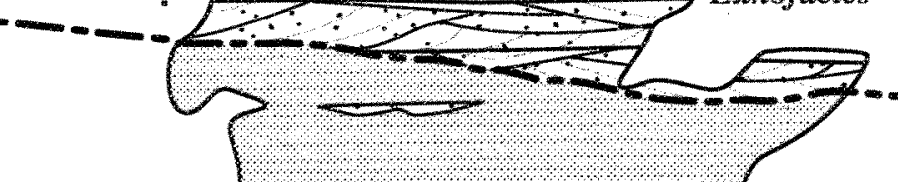

Sandstone-Siltstone
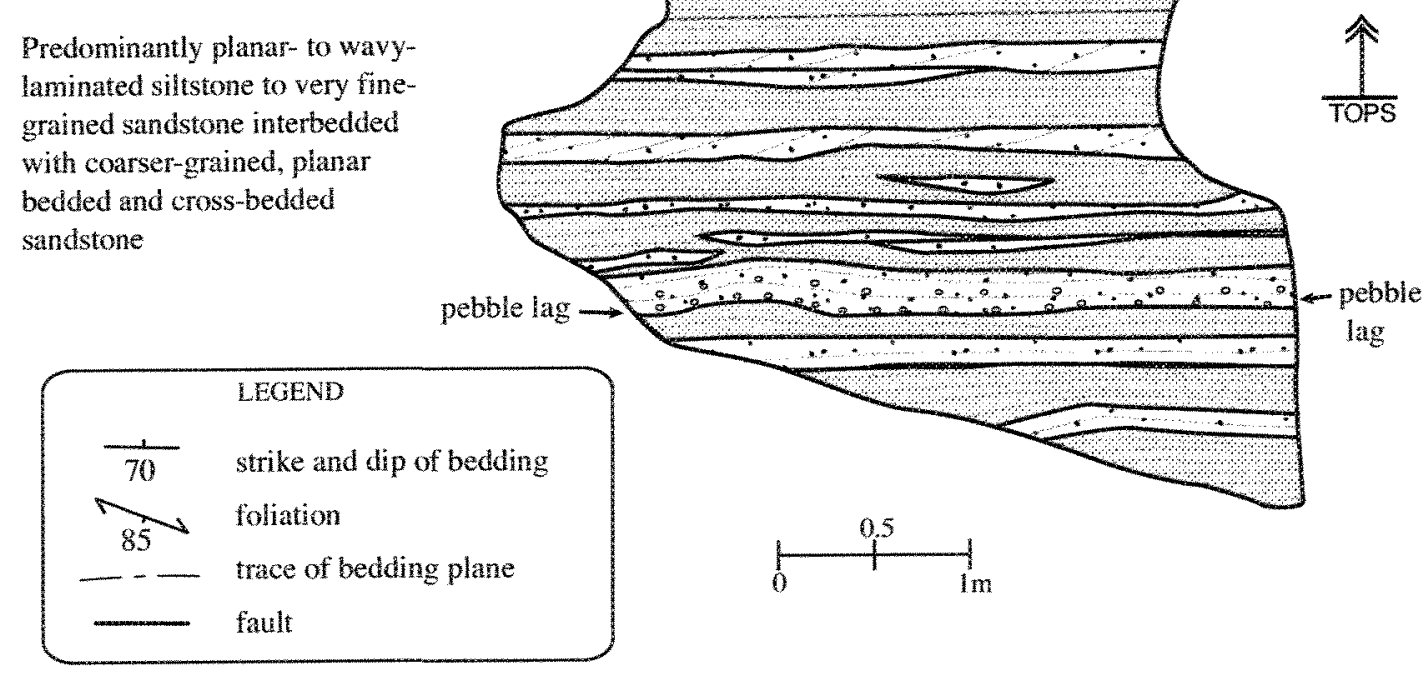

Figure 4.1. Detailed outcrop sketch revealing the transition from the wavy-to planar-bedded siltstone sublithofacies to sandstone-siltstone lithofacies and the corresponding sedimentary structures. 


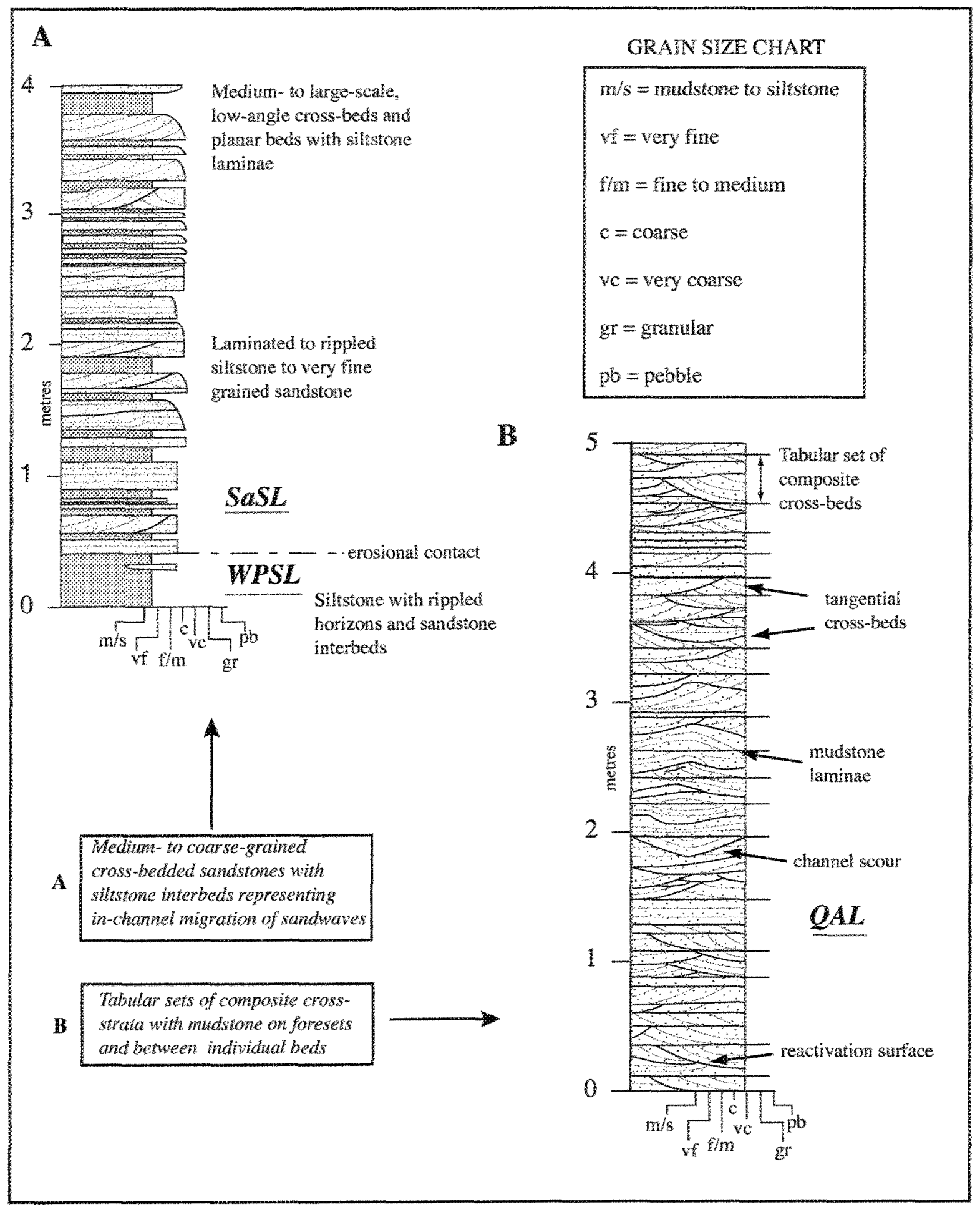

Figure 4.2. Stratigraphic columns of (A) the transition between the wavy-to planar-bedded siltstone sublithofacies (WPSL) and the sandstone-siltstone lithofacies (SaSL) and (B) the quartz-arenite lithotacies (QAL). 
the WPSL. Primarily, tidal influence and subordinate wave and storm activity are envisaged. Support for tidal influence in the SaSL includes abundant bimodal-bipolar tangential cross-bedding, reactivation surfaces and mudstone drapes, while pebble lags and rippled horizons indicate storm- and wave-influence, respectively. Together, these bedforms represent migrating sandwaves and/or tidal ridges (Johnson \& Baldwin 1996) within subtidal channel-fill deposits (Visser 1980). Coarser-grained material of the SaSL was deposited in the tidal channels where current is strongest and finer-grained material settled on the banks of these channels (WPSL). As can be seen in Figure 4.1, the downcutting trend of the SaSL is indicative of lateral migration of a tidal channel into the adjacent subaqueous tidal flats (i.e. a topographic high in relation to the channels) (Mueller et al. 2001).

The conglomerates of the QPSL are underlain by and interstratified with coarsegrained cross-bedded sandstones characteristic of the SaSL. Stratified conglomerate beds containing sandstone interbeds can represent gravel sheets formed by high-energy conditions induced by waves (Hart and Plint 1995), however, the presence of mudstone drapes indicates suspension deposition and lower flow-energy conditions (Prothero \& Schwab 196). The QPSL may also represent coastal gravel bars oriented parallel to incoming and outgoing tidal currents and perpendicular to longshore currents. According to Mueller et al. (2001), laminated sandstone and siltstone interbedded with conglomerate support wave- and tide-influence on the subaqueous component of a fan-delta. Consequently, the QPSL representing subaqueous coastal gravel bars is favored in this current study.

Tabular sets of compound and large-scale cross-strata containing distinct bounding surfaces in the QAL can be tide-generated and conceivably represent sandwave/megaripple migration (Simpson \& Eriksson 1991). The presence of superimposed ripples along larger bedforms further supports this inference (Chakraborty \& Boss 1990). Figure 4.2 B is a five meter stratigraphic column illustrating the distinguishing characteristics of the QAL, including tabular composite bedforms, medium- to large-scale cross beds, mudstone drapes, 
reactivation surfaces and channel scours, collectively representing a vertical section through a large migrating sandwave.

\subsection{Facies Successions: Beniah Formation}

Vertical stacking of the lithofacies reveals several of coarsening-upward successions in the Beniah Formation. Well-defined successions, exemplified in Figures 4.3 and 4.4, contain a basal SiSL (characteristically fine-grained sandstone and siltstone), a middle SaSL (coarser-grained sandstone-dominated with subordinate siltstone) and an upper QAL (coarse-to very coarse-grained sandstone) with local conglomerate (CL). Incomplete successions feature a combination of these lithofacies with the absence of one or more others (Figure 4.5 B and C). Contacts between lithofacies are gradual over 1-2 $\mathrm{m}$ and each succession is separated by a flat surface that shows a sharp and abrupt change from the coarser-grained lithofacies (either the QAL or CL) to the finer-grained rocks of the SiSL. Upward coarsening successions in sedimentary basins reflect one or several depositional responses to large-scale tectonism. The scale of these successions and their repetition represent the response of first-order tectonic influence, or second order climatic and/or eustatic sea-level changes (Plint et al. 1992).

These coarsening-upward successions are widespread throughout the Beniah Formation and can be found in all study areas. Although younging indicators are equivocal in the Beniah Lake fault zone, (Location A) the overall stratigraphy does reveal a general upward-coarsening of material (Figure $4.5 \mathrm{~A}$ ). Six complete successions and at least. 6 incomplete successions were mapped with thicknesses ranging from 12 to $105 \mathrm{~m}$, with a mean of 48 metres. Two coarsening-upward successions have been identified from a $25 \mathrm{~m}$ section in Location B-2, the area revealing the depositional contact between sedimentary and volcanic rocks (Figure 2.11). Three more successions are found in Location C-1 and another two have been identified at $\mathrm{C}-2$, approximately $450 \mathrm{~m}$ due west. Figures 4.3 and 4.4 illustrate stratigraphic sections compiled from both the eastern and western parts of study area C (C-1 \& C-2 respectively), with Figure 4.3 including a summary of the thicknesses for all coarsening-upward successions in the Beniah Formation and Figure 4.4 


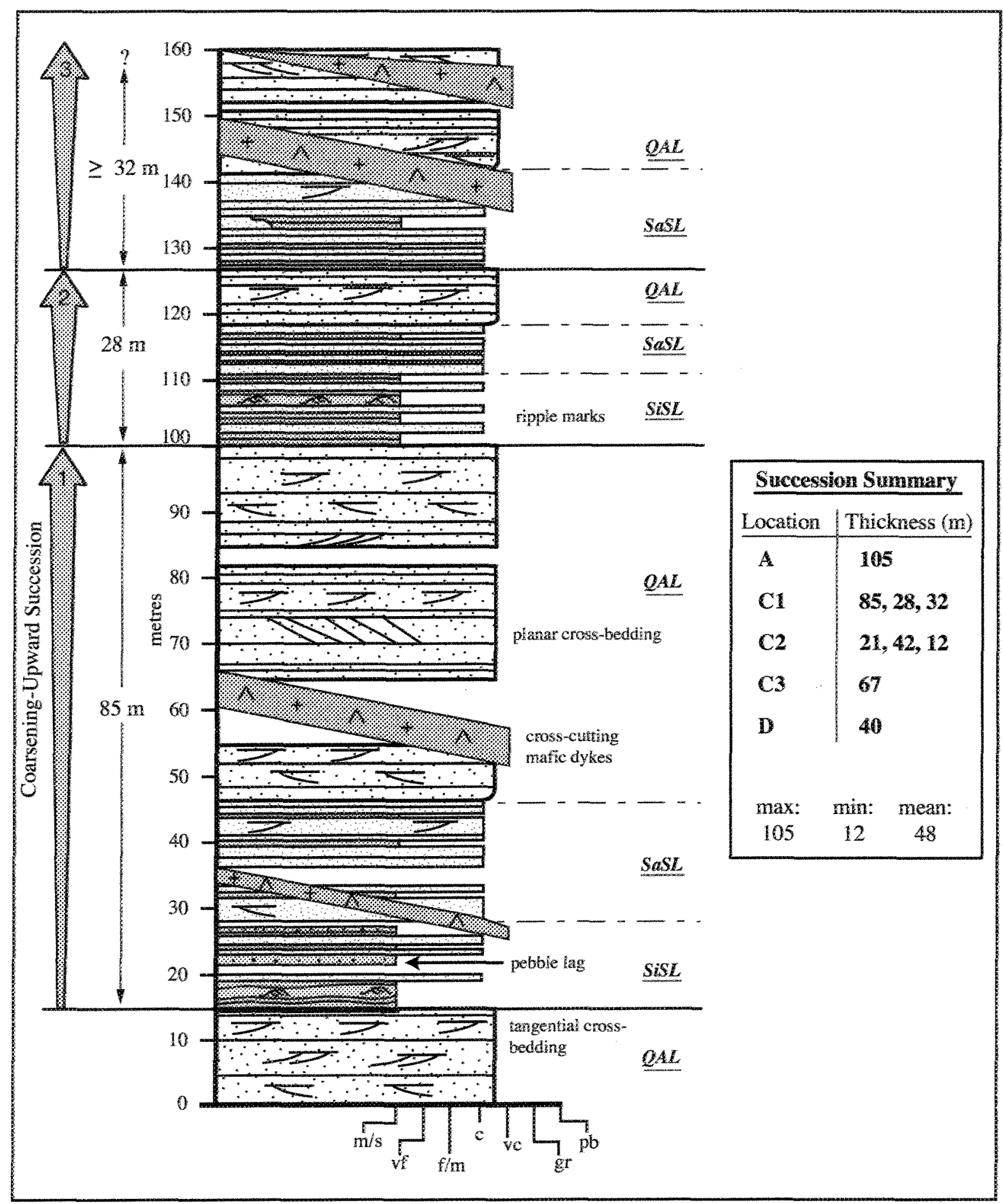

Figure 4.3. Composite stratigraphic section (160 m) from Location $\mathrm{C}-1$ indicating three coarsening-upward successions. SaSL - sandstone-siltstone lithofacies; SiSL - siltstone-sandstone lithofacies; QAL quartz-arenite lithofacies. Dashed Hnes indicate gradational contacts, whereas solid lines represent sharp contacts. Also indicated is a summary of the thicknesses of all coarsening-upward successions throughout the Beniah Formation. 


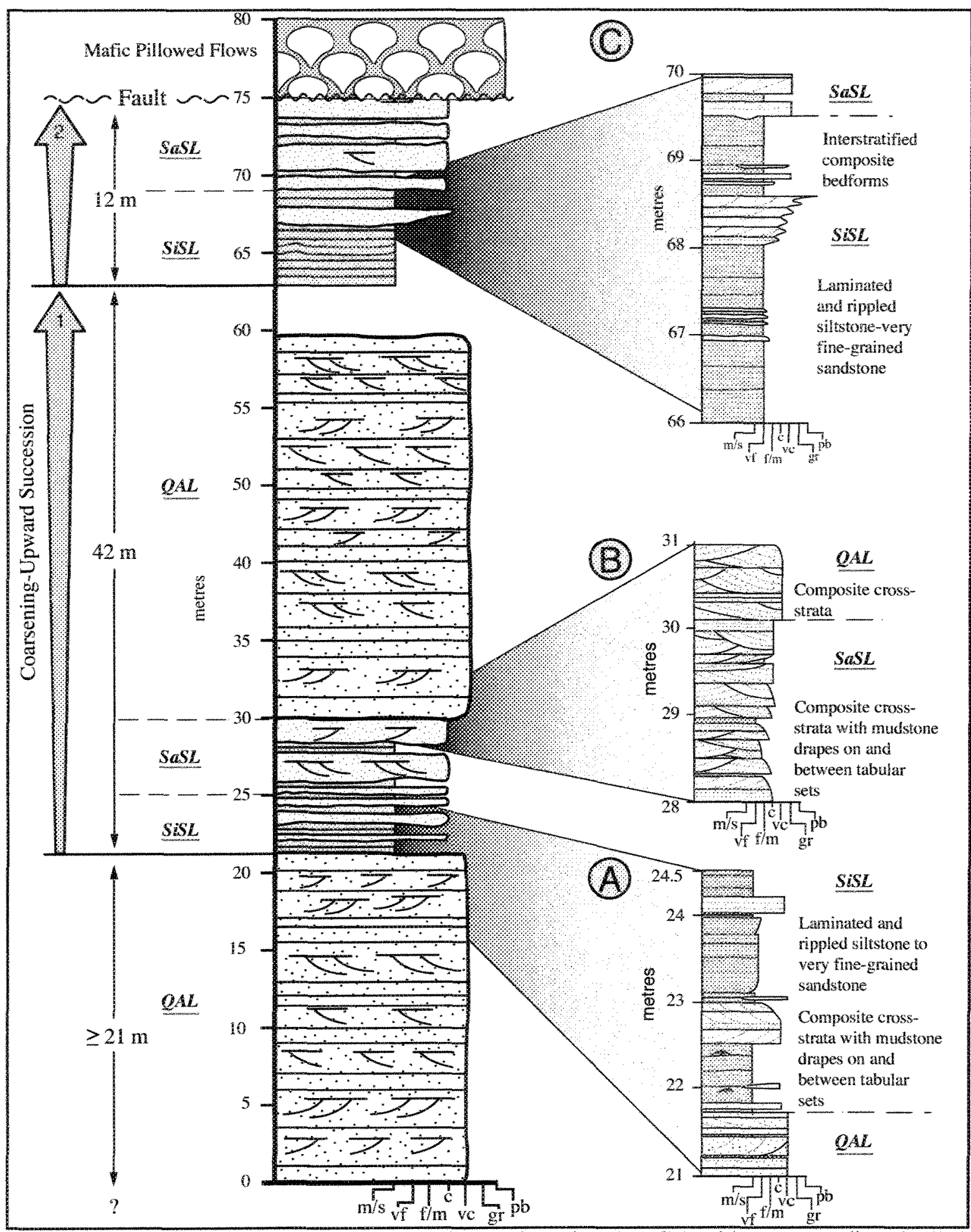

Figure 4.4. Composite stratigraphic section $(80 \mathrm{~m})$ from location $\mathrm{C}-2$ with corresponding detalled stratigraphic columns $\mathrm{A}, \mathrm{B}$, and $\mathrm{C}$ and prominent sedimentary structures. Note the presence of at least two coarsening-upward successions. SaSL - sandstone-siltstone lithofacies; SiSL siltstone-sandstone lithofacies; QAL - quartz-arenite lithofacies. 


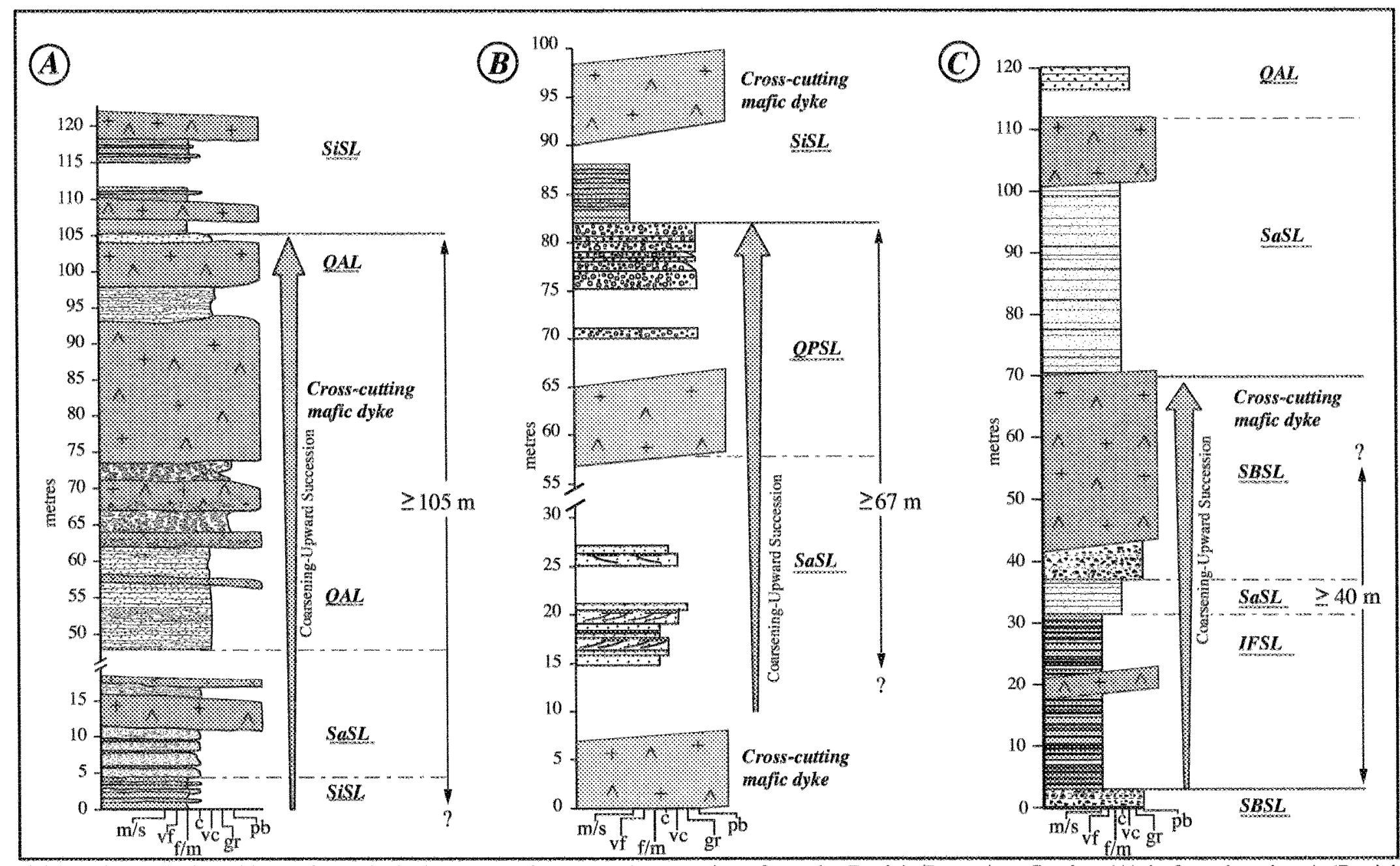

Figure 4.5. Stratigraphic sections displaying coarsening-upward successions from the Beniah Formation. Section (A) is from location $\mathrm{A}$ (Beniah Lake fault zone), (B) is from location C-3 (central Beniah Lake), and (C) is from location D (southeast of Beniah Lake). See Figure 1.1 and Appendix 1 for specific locations. IFSL - iron formation sublithofacies; SaSL - sandstone-siltstone lithofacies; SBSL - sedimentary breccia sublithofacies; SiSL - siltstone-sandstone lithofacies; QAL - quartzarenite lithofacies; QPSL - quartz-pebble conglomerate sublithofacies. 
showing detailed stratigraphic columns that represent the distinct lithofacies and their corresponding sedimentary structures. The upper and lower extents of each complete succession is indicated by the solid lines, whereas transitional lithofacies within each succession is marked by the dashed line. The contact between the SaSL and overlying mafic volcanic unit in Figure 4.4 is interpreted to be an unconformity separating the $\sim 2.8$ $\mathrm{Ga}$ Beniah Formation from ca $2.7 \mathrm{Ga}$ mafic flows equivalent to the Beaulieu River volcanic belt. In addition to these examples, three more stratigraphic sections from locations $\mathrm{A}, \mathrm{C}-3$ and D also reveal coarsening-upward successions and are illustrated in Figure 4.5.

\subsubsection{Significance of Coarsening-Upward Successions}

Coarsening-upward successions in the sedimentary rock record are important features that can be associated with change in sea-level change and large-scale tectonism. Increasing water depth from subsidence results in an increased sediment supply coincident with an overall deepening of the basin (i.e. transgression). In contrast, basin uplift causes a decrease in sea level and reduce sedimentation rates within the basin (i.e. regression) (Prothero \& Schwab 1996). Crustal attenuation, such as sea-floor spreading, is a long-term cause of sea level shifting (over $10^{3}-10^{8}$ years) (Plint et al. 1992). In relation to extensional tectonic movement, periodic fault uplift of the source rock has been attributed to the formation of coarsening-upward successions (Rust \& Koster 1984).

Most siliciclastic successions in the sedimentary record are progradational, in which younger lithofacies up-section are deposited in progressively shallower water (Van Wagoner et al. 1990). Within each succession, lithofacies and individual beds generally thicken upward, sandstone/mudstone ratio and grain size increases and lithofacies tend to "shoal" upward. These characteristics are notably similar to the coarsening-upward successions of the Beniah Formation. .

Other cyclical siliciclastic successions from ancient shallow-marine settings can be compared with the Beniah Formation. A proposed depositional model for the Mahantango Formation, from the Middle Devonian of the central Appalachian, USA is one such example (Duke \& Prave 1991; Prave et al. 1996). The authors observed a series of upward- 
coarsening successions, $10-60 \mathrm{~m}$ thick, revealing a transition from siltstone to fine- and medium-grained sandstone to coarse- and very coarse-grained sandstone to conglomerate. Many sedimentary structures, including tangential cross-bedding, pebble lags, combined flow ripples and mudstone drapes are similar in form and scale to those in the Beniah Formation. Paleocurrent data, characteristic structures and lithofacies associations, analogous to the Beniah Formation, allude to a shallow marine tidal- and storm-influenced setting. Cyclicity in the Mahantango Formation is associated with repeated progradation and brief retreat of a tide-dominated shoreline, resulting in the upward-shoaling of the lithofacies. Progradation is caused by active tectonic uplift along the active margin of the Appalachian foreland basin. Successions of the Beniah Formation display an overall shoaling in a tide-influenced setting, although there is no evidence for an active margin along a foreland basin,

A second example of upward-coarsening successions is from the Early Proterozoic Wishart Formation in northeastern Quebec (Simonson 1984). The 8-20 m-thick successions were interpreted to have formed in a high-energy shelf environment and the upwardcoarsening successions have been attributed to shelf aggradation during pulses of more rapid sedimentation. It is plausible that the Beniah Formation coarsening upward successions were formed by progradational-aggradational processes similar to those that were responsible for deposition of the Wishart and Mahantango formations. The development of the coarsening-upward successions in the Beniah Formation is inferred to reflect a combination of eustatic sea level change (through uplift and/or basin subsidence), as well as an influence on sedimentation by tectonic activity. The thickness of these successions and their repetition represent the response of large-scale tectonic influence and climatic or eustatic sea-level change. Sea level change is inferred to have more local and short-term influence on creating the coarsening-upward successions, coupled with tide, wave and storm influence, whereas tectonic crustal attenuation and rifting are more larger and long-term, transpiring over millions to tens of millions of years. 


\subsection{Depositional Setting: Beniah Formation}

Determining the depositional setting for the sedimentary rocks is an integral part of facies analysis. In doing so, interpretation of successions is elucidated and a facies model can be established. The abundance of sedimentary structures including tabular sets of composite cross-strata, ubiquitous mudstone drapes, well-rounded, massive and stratified conglomerate and interbedded sandstone and siltstone, are consistent with a shallow marine shelf-type setting for the Beniah Formation. The vertical stacking of lithofacies (i.e. lithofacies succession) reveals a transitional offshore setting, represented by the siltstonesandstone lithofacies, to a lower to middle shoreface (the sandstone-siltstone lithofacies) and upper shoreface setting (quartz-arenite lithofacies) with local subaqueous beach counterparts, such as longitudinal gravel bars (conglomerate lithofacies). Figure 4.6 is a simplified profile of a shallow-marine setting and the approximate location of the distinct lithofacies has been indicated.

In addition to the proposed shoreface setting for the Beniah Formation, the SaSL and WPSL exemplify tidal channel-tidal shoal complexes in the mouth of an embayment or estuary. Stratigraphic sections from modern estuarine settings show tidal bars with upwardthickening and coarsening sediment with rippled and cross-bedded sands containing abundant mud laminae (Allen 1991) that are remarkably similar to the transitional WPSL and SaSL depicted in Figures 4.2 and 4.4.

The abundance of fine-grained material, planar to wavy bedforms and local pebble lags in the SiSL are indicative of a transitional offshore to lower shoreface setting. Graded beds found in the SiSL indicate deposition below the mean storm wave base (Hamblin \& Walker 1979) and pebble lags deposited immediately following intense storms or flash floods. Interbedded sandstones in the WPSL reflect alternating fairweather and storm deposits in a proximal offshore to lower shoreface environments (Okazaki \& Masuda 1995).

Moderately- to well-sorted, medium- to coarse-grained sandstones containing composite cross-bedding and numerous mudstone drapes (SaSL) are consistent with a 


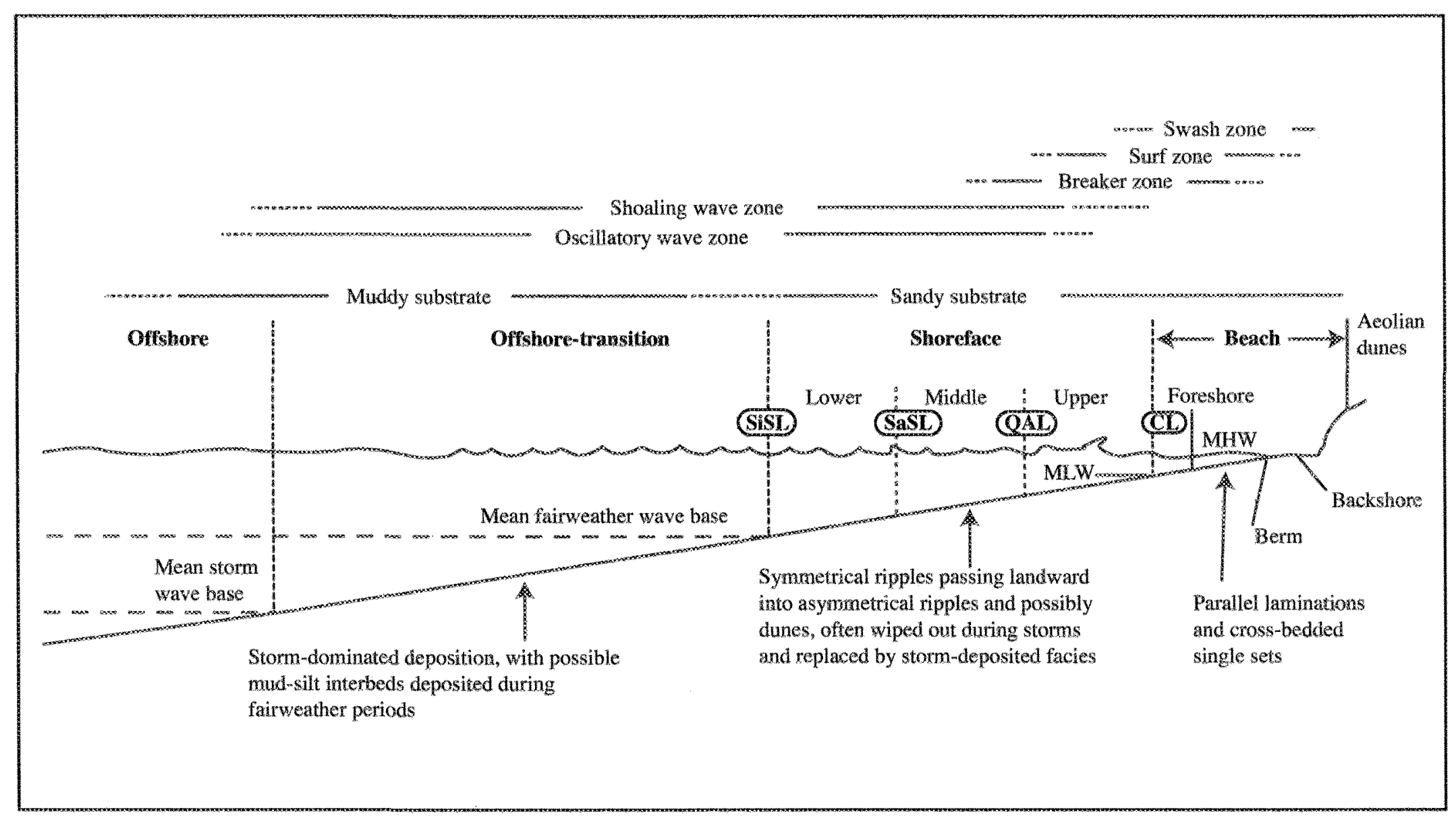

Figure 4.6. Simplified profile of a shelf-type shallow-marine setting with the approximate location of the Beniah Formation lithofacies. Modified from Reading \& Collinson (1996) and Walker \& Plint (1992). MHW = mean high water; MLW = mean low water. 
transitional moderate- to high-energy environment containing tidal-channel deposits, possibly within an embayment mouth complex (Johnson \& Levell 1995). Storm influence along the proposed coastline gains support through the identification of pebble lags and siltstone-sandstone interbeds within the SaSL and WPSL. Continued wave and tidal action, as well as lower sedimentation rates may not have allowed for the preservation of hummocky cross-stratification or swaley cross-stratification in the sedimentary record.

Bimodal, bi-polar paleocurrent patterns from the QAL are generated by shoaling of wayes near the shoreline and are characteristic of a subtidal environment influenced by a dominant tidal current in a middle to upper shoreface setting (Johnson \& Baldwin 1996). The coarse- to very coarse-grained tabular sets of tangential cross-bedded sandstone with unimodal paleocurrent patterns reflect a high energy tide-dominated complex, consistent with those found within an estuary/embayment mouth or open marine sea strait (Johnson \& Levell 1995). The conglomerates of the QPSL are probably the subaqueous coastal counterpart of this sedimentary succession. Interfingering conglomerates with crossstratified sandstones are indicative of upper shoreface settings and lower beach facies often contain thick, moderately- to well-sorted, clast-supported conglomerates (Johnson \& Baldwin 1996).

\subsection{Lithofacies Analysis of the Bell Lake Formation}

Facies association of the Bell Lake Formation advocates tidally-influenced sheet sands or tidal bars. Low-angle cross-beds, abundant parallel laminae, mudstone drapes, thythmically layered sandstone and siltstone are consistent with sheet sandstones formed in shelf and estuarine settings (Ehlers \& Chan 1999; Johnson \& Baldwin 1996).

Stacking of the Bell Lake Formation lithofacies reveals a relatively thick basal QAL overlain by the SaSL with local quartz-arenite interbeds. Thin veneers of the iron-formation are the predominant lithofacies in the upper stratigraphy of the Bell Lake Formation, therefore indicating an upward-fining facies succession. The thickness of these successions range between 20 and $40 \mathrm{~m}$, however the ubiquitous mafic dykes and sills obscure their true thickness. The Bell Lake Formation is overlain by a thick succession of subaqueous 
mafic volcanic rocks, however the relationship between the sedimentary rocks and the overlying flows remains uncertain.

The QAL, characterized by stacked tabular sets of low-angle tangential cross-beds and flat parallel laminae, represents tide- and wave-influenced sheet sandstones on an open shelf (Ehlers \& Chan 1999). The transition from SaSL to IFL indicates subtidal flats characterized by rhythmic layering of sand and silt (Nio \& Yang 1991; Miller \& Eriksson 1997). More specifically, the heterolithic (sandstone vs. siltstone) layering seen in parts of the SaSL and throughout the IFL could be related to neap-spring tidal cycles (Ehlers \& Chan 1999). Laminated fine-grained sandstones $(5-15 \mathrm{~cm}$ thick) represent semimonthly spring tides and thin siltstone/mudstone layers $(0.5-5 \mathrm{~cm}$ thick) correspond to the neap counterpart of the tidal cycle. Hence, the Bell Lake Formation represents a transition from a middle to upper shoreface setting with strong tidal influence. 


\section{CHAPTER 5}

\section{DISCUSSION/CONCLUSIONS}

\subsection{Introduction}

The history of the Beniah and Bell Lake formations can be placed in a coherent geological context through an integration of detailed facies analyses, stratigraphic relationships, lithofacies stacking and paleo-reconstruction. Other factors required in defining this depositional model include provenance and tectonic influence so that a valid paleoenvironmental setting may be proposed. In order to place the Beniah and Bell Lake formations into a geodynamic context, these aspects must be considered.

\subsection{Provenance}

Determining the source of the quartz-arenites and related rocks should be relatively straightforward, considering that the Beniah Formation directly overlies a tonalitic gneissic basement. However, creating mineralogically mature sandstones by simply shedding detritus from tonalitic rocks is problematic. An average tonalite generally contains 15.94\% quartz (Rollinson 1994), therefore, the amount of eroded tonalite required to form hundreds of metres thick of quartz-arenite beds is considerable. Point-counting of the Bell Lake basement has shown that the rocks are quartz-rich, however a more in depth petrographic study of the Beniah Lake basement rocks would improve the understanding of the source rocks for the quartz-arenites of this area. Other studies suggest that intense chemical weathering and rigorous transport of sediment with episodes of prolonged crustal stability would produce mineralogically mature rocks (Srinivasan \& Ojakanagas 1986; Eriksson et al. 1994; Donaldson \& de Kemp 1998). It is therefore conceivable that these 
factors played a role in producing the quartz-arenites of the Beniah and Bell Lake formations.

The quartz-arenite successions of the Beniah Formation could have resulted from multiple sedimentary cycles. Pre-existing arkose or litharenite sandstone bodies may have been eroded, reworked and redeposited, thus allowing for further removal of feldspars and lithic fragments. The abundance of mica in the Beniah Formation sandstones is consistent with an initial presence of feldspar grains that were mechanically broken down and chemically altered to clay minerals, such as illite and/or kaolinite. Subsequent metamorphism and addition of fluids produced muscovite and other phyllosilicates. Several thin-sections display mica crystals that roughly preserve the form of the original feldspar grains (Plate 3.6 C). This suggests that the Beniah Formation sandstones were initially less mature than they currently appear.

Many quartz-arenite successions have been attributed to sedimentary recycling (Suttner et al. 1981; Chandler 1988). Feree et al. (1988) studied the relationship between petrographic maturity and the origin of quartz-arenites whereby subsequent sedimentary cycles resulted in converting initially arkosic and lithic arenites to pure quartz-arenite sandstones. The deconstruction of the feldspars and lithic fragments through recycling ultimately produces a mineralogically mature end-member. In contrast to this supposition, no known, older sedimentary rocks that could act as a source have been clearly identified in the Slave Province.

The finer-grained material from the SiSL, containing abundant biotite, chlorite, and sericite, indicate a mafic source. This is commensurate with the presence of pyroxenite and dunite layered complexes in the Beniah Lake area. Based on the stratigraphic evidence from Beniah Lake, these layered intrusions were emplaced near the basal portion of the Beniah Formation, immediately above the basement. Chromite grains from the quartzarenite beds show geochemical characteristics similar to those from the local dunite bodies (Fyson, unpublished notes), thus supporting that the detrital chromite was derived from the ultramafic sills. 


\subsection{Tectonic Influence on Sedimentation}

Early interpretations of the relationship between the quartz-arenite and ultramafic rocks at Beniah Lake suggested that the layered intrusions were anorogenic (Covello et al. 1988). According to Roach \& Fyson (1992), the protocontinental shelf upon which the Beniah Formation sedimentary rocks were deposited underwent limited extensional events whereby isolated crustal fractures tapped an ultramafic source from the mantle and facilitated the emplacement of the layered complexes. This supports the notion that ultramafic layered bodies are commonly associated with rifts (Raymond 1995).

Coarsening-upward successions have also been interpreted to be the products of source area uplift and erosion following tectonic activity (Hartly 1993). Faulting along a marine shelf, with abrupt and significant tectonic movement, would favor marine flooding, thus increasing sedimentation rates and producing coarsening-upward successions (Mueller et al. 2001). Although similar successions described by Prave et al. (1996) and Simonson (1984) have been interpreted to represent eustatic sea level change and basin subsidence as the key to their development, Johnson \& Baldwin (1996) and Reading \& Collinson (1996) argue for the influence of tectonism along a rifted continental margin. It is plausible that a combination of eustatic sea level change in the form of transgressive-progradational cycles, governed by periods of extension, resulted in the formation of coarsening-upward successions of the Beniah Formation.

Mafic dyke swarms have been documented in various locations in the Slave Province, however many of these dykes have ages of $2.7 \mathrm{Ga}$ or younger (Helmstaedt et al. 1986; Lambert et al. 1992; MacLachlan \& Helmstaedt 1995; Bleeker et al. 1999) Based on structural measurements and deformation patterns, at least two series of mafic dykes have been found to predate deposition of the Yellowknife Supergroup. These include mafic dykes mapped in the Fenton-Brown lakes area (James \& Mortensen 1992) and in the Sleepy Dragon Basement Complex (Kusky 1990). There are probably several generations of dyke swarms in the Slave Province and until precise ages are established, it is possible that some of these are related to the $2.8-2.9 \mathrm{Ga}$ basin-forming event and could be feeders to the local volcanic flows that conformably overlie the Beniah Formation. 
The depositional contact between the sedimentary rocks and overlying pillowed flows provides evidence that mafic volcanism is temporally and spatially related to the Beniah Formation and conceivably reflects the late stages of crustal attenuation. Initial rifting, possibly generated by the presence of a hot spot, is attended by stretching and subsidence of the lithosphere (Dickinson 1980) resulting in magma upwelling and rising of the mantle. Episodic extensional events caused faulting and down-dropping of the protocontinental shelf, eventually tapping into volcanic sources below, which use the faults as conduits to reach the surface. The result is the emplacement of effusive volcanic flows that cover the shallow marine sedimentary rocks of the Beniah Formation.

\subsubsection{Tectonism and Basin Development}

The Slave Province hosts many quartz-arenite successions in addition to the Beniah and Bell Lake formations, including those mapped at Brown Lake; Patterson Lake and Winter Lake. Figure 5.1 illustrates the location of these basins as well as the extent of the gneissic basement complexes mapped by Bleeker et al. (1999) and Isachsen \& Bowring (1997). It is observed that the basement and overlying $\sim 2.8 \mathrm{Ga}$ sedimentary rocks are all found adjacent to north-trending crustal-scale faults, such as the Beniah Lake and the ancestral Jackson Lake fault zones (Corcoran et al. 1998). The boundaries of an early Archean continent can be outlined using the location of these basement and cover sequences (Figure 5.1).

Figure 5.2 illustrates the proposed tectonic scenario for the Slave Province based on the basement-cover sequences and their spatial relationship with the north-trending crustalscale faults. It is probable that the crustal-scale fault zones, reflecting extension from riftrelated tectonism, directly influenced sedimentation of the cover successions (Figure 5.2 A1). Subsequent periods of extension attenuated the basement and faulted, down-dropped blocks became sites for ca $2.8 \mathrm{Ga}$ sedimentary basins, which were filled by clastic debris derived from the adjacent topographic highs (Figure $5.2 \mathrm{~A}-2$ ). Each rifting phase began with a basal siltstone-dominated sedimentary unit, reflecting flooding of the platform due to extension. As tectonic uplift, in conjunction with basin subsidence continued, increased 


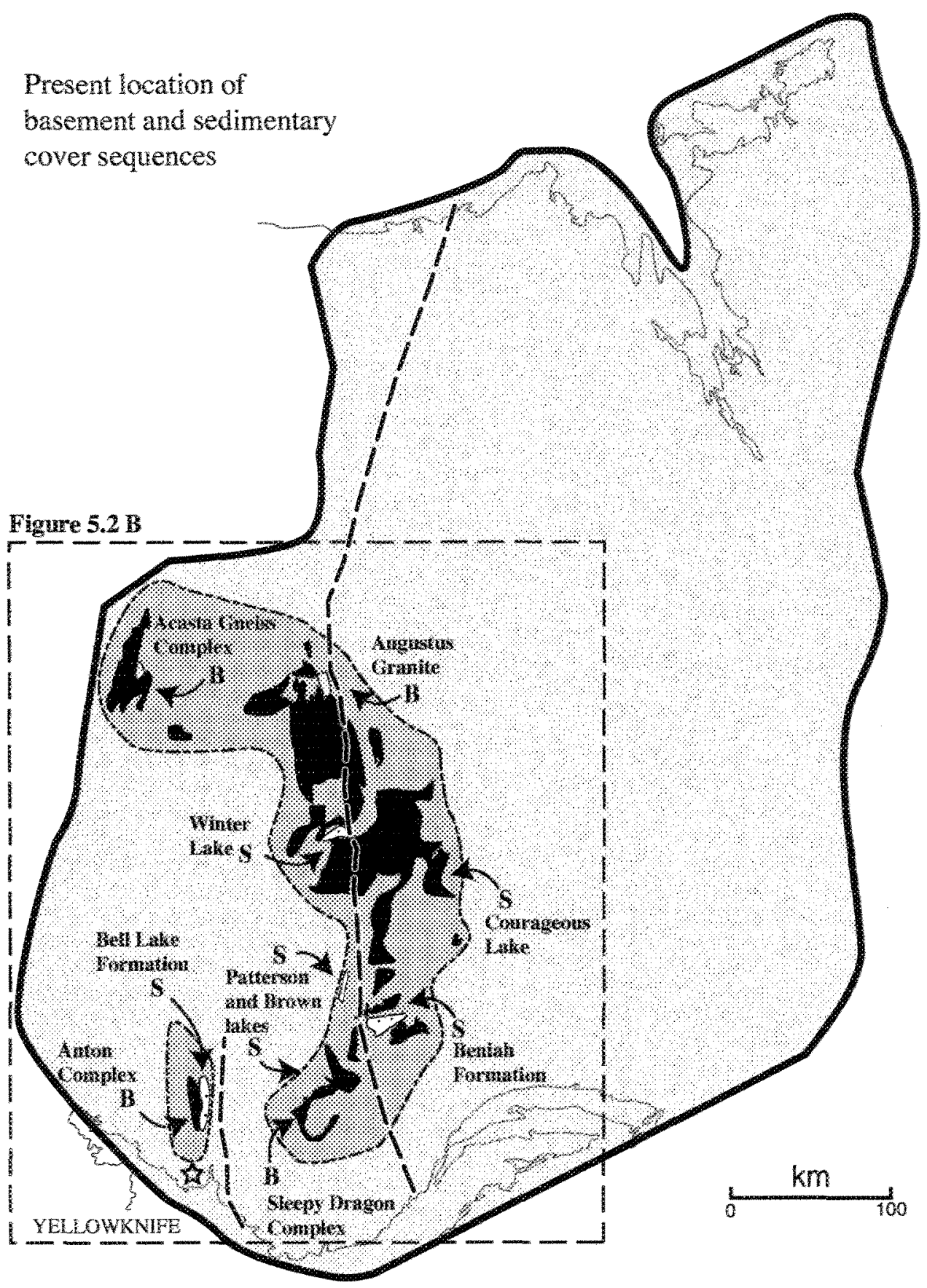

Figure 5.1. Distribution of the basement-cover sequences throughout the Slave Province. The location of the basement rocks (B) and sedimentary basins (S) are derived from Bleeker et al. (1999) and Isachsen \& Bowring (1997). 


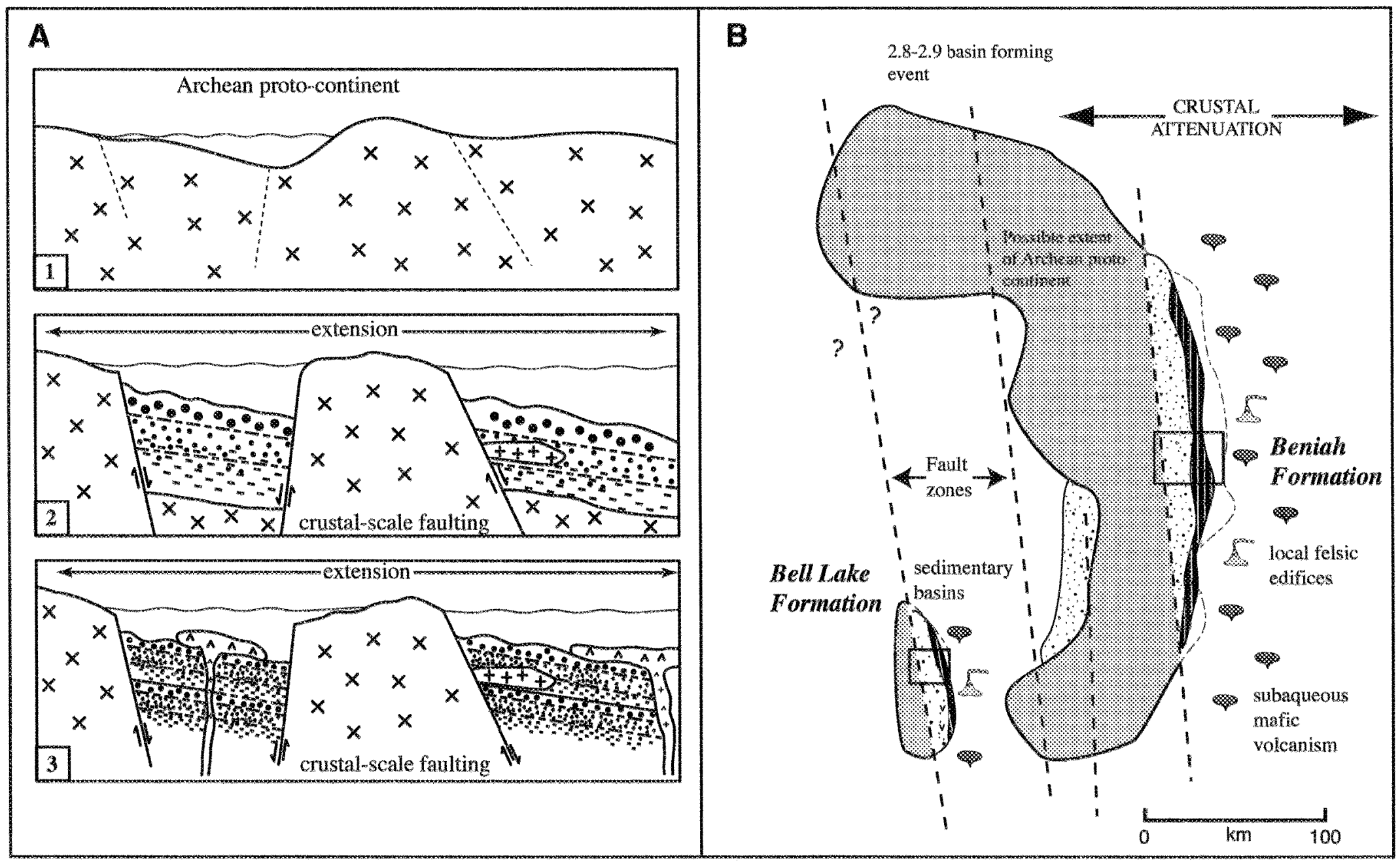

Figure 5.2. Proposed tectonic scenario for the formation of the siliciclastic sedimentary basins throughout the Slave Province including the Beniah and Bell Lake formations. (A) Cross section of basin-forming event. (A-1) Archean protocontinent. (A-2) Early stages of rifting, faulting and development of coarsening upward sequences. (A-3) Late stages of rifting with contemporaneous volcanism. The vertical scale has been exagerated to illustrate the coarsening-upward successions. (B) Plan view of basement-cover sequences for the entire Slave Province (see Fig. 5.1). 
erosion rates along faults and/or the basin margin produced coarser-grained lithofacies such as the quartz-arenite and sandstone-siltstone lithofacies. The final stages of extension resulted in the emplacement of effusive subaqueous volcanic flows that locally cover the sedimentary sequence (Figure $5.2 \mathrm{~A}-3$ ). Both rapid transgression of a platform with progressive basin filling and slow transgression along the shores of a crustal block in an estuarine setting could give rise to coarsening-upward successions however, extension from rift-related tectonism is favored.

It is inferred that quartz-arenite sequences are the result of several sub-basinal events rather than one extensive basin (Figure 5.2 B), because the sedimentary cover sequences vary in thickness $(<0->700 \mathrm{~m})$ and dissimilarities are observed in the lithofacies stacking from one sequence to the next. Nevertheless, it is clear that a widespread development of sedimentary basins formed on a proto-continental shelf that underwent phases of extensional tectonism and crustal attenuation approximately 2.8 billion years ago.

\subsection{Paleogeographic Reconstruction}

\subsubsection{Beniah Formation}

It has been established that the Beniah Formation represents a sedimentary succession deposited in a shallow marine shelf-type setting with tide, wave and minor storm influence. The lithofacies provide evidence for the presence of tidal channels (WPSL and SaSL) within an estuarine embayment complex, subaqueous coastal gravel bars (QPSL), migrating sand dunes (QAL) and interstratified subtidal silt-sand plains (IFSL). A 3-D model corresponding to the paleogeographic reconstruction of the Beniah Formation is illustrated in Figure 5.3.

The model shows a coastal setting with an embayment; the extension of an estuary fed by a braided river system in the hinterland. Within the estuary-embayment complex, tidal channels and shoals are formed. The channels contain medium- to coarse-grained cross-bedded sands, corresponding to the SaSL. Channel levees contain predominantly planar to wavy laminated, rippled, fine-grained sand and silt (SiSL). In the open coastal area, wave and current conditions are stronger, giving rise to coarser-grained sediment. 


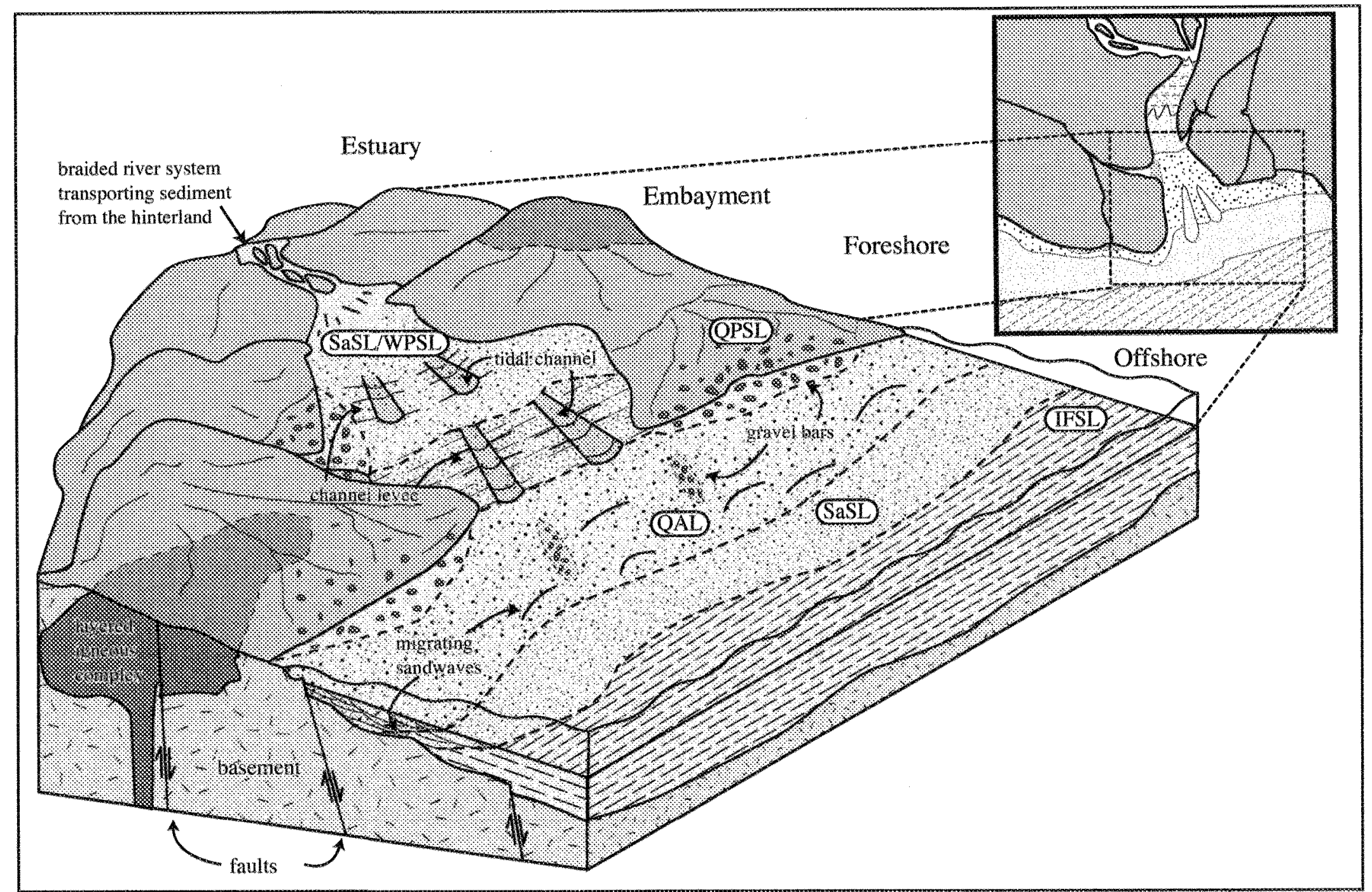

Figure 5.3. Paleogeographic reconstruction of the Beniah Formation based on sedimentary structures and lithofacies association. IFSL - iron formation sublithofacies; PWSL - planar-to wavy-bedded sublithofacies; QAL - quartz-arenite lithofacies; QPSL - quartz-pebble conglomerate sublithofacies; SaSL - sandstone-siltstone lithofacies. 
This is represented by the QPSL in the form of coastal and longitudinal gravel bars. Tide and wave action is persistent in the shoreface resulting in the formation of laterally extensive migrating sandwaves (QAL). The transition from shoreface to offshore is characterized by smaller-scale bedforms and a reduction in grain size, consistent with the SaSL and BIFSL.

The model also depicts faulting of the basement rocks and the presence of the igneous layered complex. They are the result of periodic extension and crustal thinning along a rifted margin. Continuous periods of crustal attenuation and rifting result in effusive volcanic activity, as well as the emplacement of mafic dykes. Figure 5.4 represents the final stages of basin development whereby extension of the shelf gives rise to effusive volcanic flows that cover the sedimentary rocks..

\subsubsection{Bell Lake Formation}

The lithofacies and corresponding sedimentary structures for the Bell Lake Formation can be utilized to reconstruct depositional setting (Figure 5.5). An unprotected, tidedominated coastal setting with reduced topographic highs in the hinterland analogous to the east coast of the USA is envisaged. Stacked tabular bodies of blanket sands, formed by migrating sandwaves, cover the upper shoreface of this passive margin. In the stratigraphic record, this corresponds to the planar bedded and tabular cross-bedded sandstones of the QAL that directly overlie the basement. Rhythmically layered sand and silt, generated by tides, are more prominent in the middle to lower shoreface and are represented by the SaSL and BIFL.

\subsection{Archean Analogues}

The following section will examine examples of Archean supracrustal sequences from locations around the world and compare them with the Beniah and Bell Lake formations. Various constituents including basement composition, lithofacies morphology, the presence or absence of volcanic activity, age and the overall thickness of the sequences will be considered. 


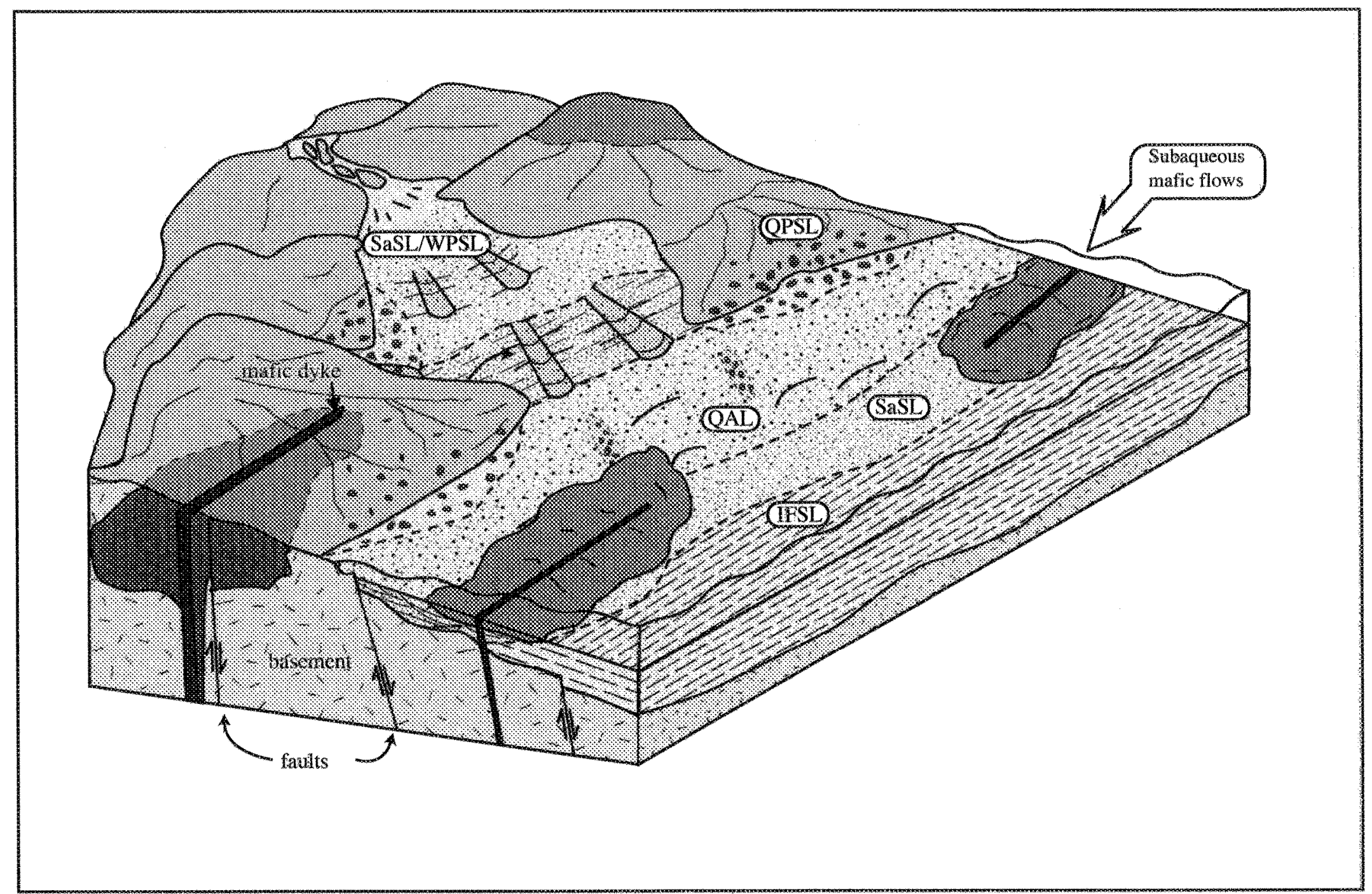

Figure 5.4. Contemporaneous effusive volcanism daxing the final stages of development of the Beniah Formation ca. $2.8 \mathrm{Ga}$. 


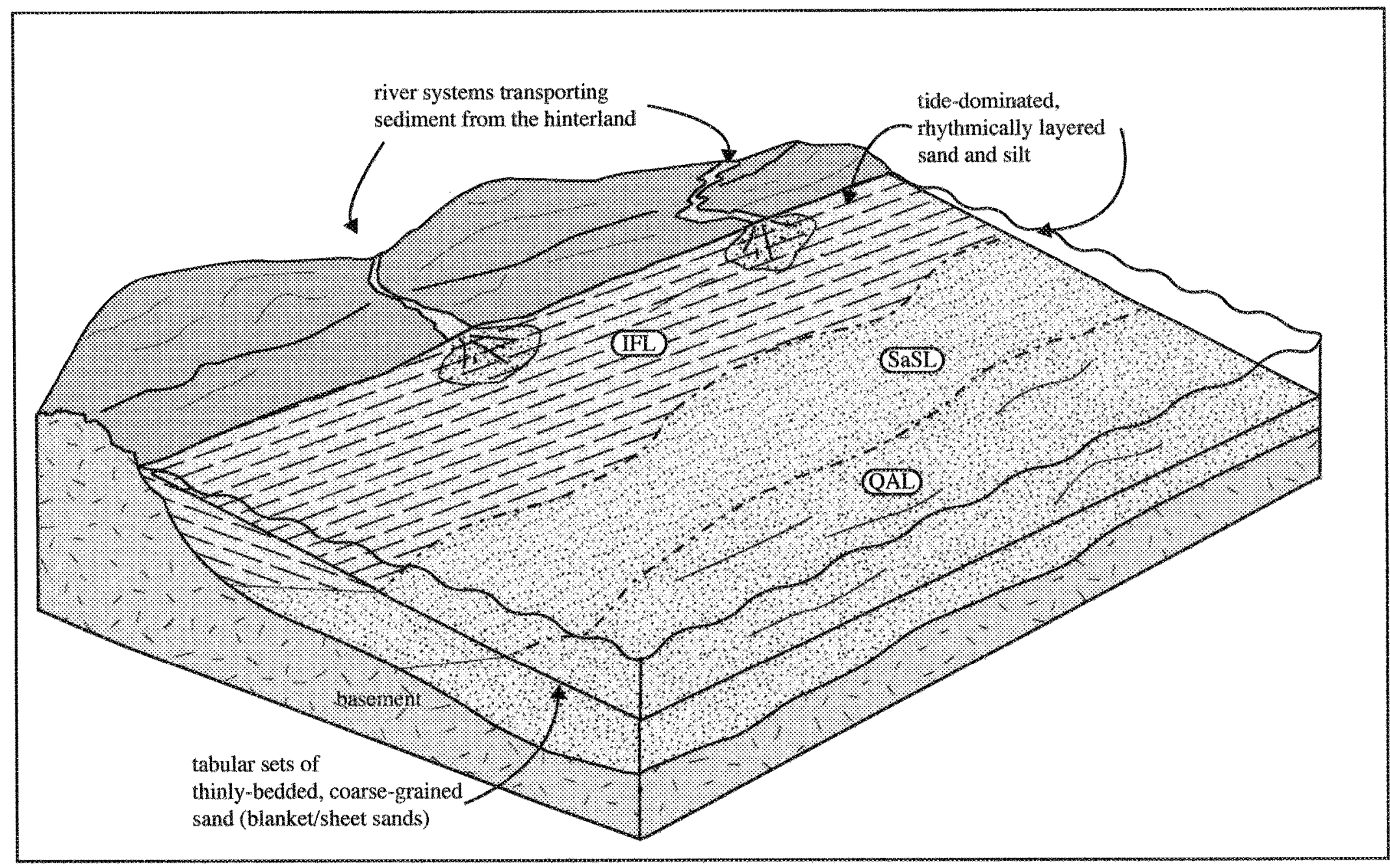

Figure 5.5. Paleogeographic reconstruction of the Bell Lake Formation based on sedimentary structures and lithofacies association. The model represents the shoreface of an unprotected siliciclastic shelf. IFL - iron formation lithofacies; QAL - quartz-arenite lithofacies; SaSL sandstone-siltstone lithofacies. 
The Bababudan Group from the Dharwar Craton of India characterized by a series of predominantly siliciclastic sedimentary and mafic volcanic rocks (ca $3200-3000 \mathrm{Ma}$ ) up to $1800 \mathrm{~m}$ thick that unconformably overlie a $>3200 \mathrm{Ma}$ gneissic basement (Srinivasan \& Ojakangas 1985). The sedimentary rocks contain texturally submature to mature crossbedded (planar and herringbone) sandstone and thin basal, clast supported quartz-pebble conglomerate interpreted to be of a braided-alluvial origin. Associated mafic volcanic rocks are also of subaerial origin. Paleocurrent analyses of cross-beds from the quartz-arenites indicate a predominant trend to the south-southeast and support a continental fluvial environment of deposition, rather than a shallow marine tidal setting. The general lack of argillite in the quartz-arenites also supports this inference. Minor pelite and iron-formation however, are interpreted as shallow-marine deposits. The authors infer that the maturity of the quartz-arenites and quartz-pebble conglomerate is a result of intense weathering of the basement granite-gneiss and deposition of the sediment on a stable platform. In addition, the mafic volcanic rocks are interpreted to reflect episodic rifting of the stable platform. The abundance of gabbroic sills that transect the Bababudan Group supports this supposition.

The Buhwa greenstone belt of the Zimbabwe Craton consists primarily of 2.9-3.1 Ga sedimentary rocks with local mafic and ultramafic volcanic rocks unconformably overlying an older gneissic basement (Eriksson \& Fedo 1994; Eriksson et al. 1994; Fedo \& Eriksson 1996). Volcanic rocks directly overly the basement and are interstratified with the banded iron-formations up-section. The age of the basement is poorly constrained and range between 3.2 $\mathrm{Ga}(\mathrm{Rb}-\mathrm{Sr})$ and $3.5 \mathrm{Ga}(\mathrm{Pb} / \mathrm{Pb})$ (Hawkensworth et al. 1975; Taylor et al. 1991, respectively).

The sedimentary succession in the Buhwa greenstone belt is divisible into three units including quartz-arenite, interbedded quartz-arenite and siltstone, and siltstone-rich units containing iron-formation and displays an upward-fining trend. Sedimentary structures, such as tangential cross-bedding, symmetrical ripple marks, mudstone drapes, and local hummocky cross-stratifications, are indicative of deposition on a shallow shelf with wave, tide and storm influence. The paleotectonic setting of the Buhwa greenstone belt, 
interpreted by Fedo \& Eriksson (1996), is considered to be a passive margin, stable shelftype setting, based on the lithological assemblages. However, the presence of mafic and ultramafic volcanic rocks indicates some crustal instability and may be associated with rifting.

A sedimentary assemblage from the Keeyask Lake area of Northwestern Ontario includes tabular-planar and tangential cross-bedded quartz-arenites with ripple marks, reactivation surfaces and pebble lag, all characteristic of deposition in a shallow-marine environment (Thurston \& Chivers 1990; Donaldson \& de Kemp 1998). In addition, the assemblage contains stromatolite interbeds, quartz-pebble conglomerate and banded ironformation. The $2980 \mathrm{Ma}$ Keeyask Lake assemblage directly overlies a $\sim 3.0 \mathrm{Ga}$ tonalitic batholith and is capped by komatiitic and tholeitic flows. The presence of the quartz-rich sedimentary assemblages of the Keeyask Lake rocks indicates crustal stability during the early Archean. In contrast, the direct association of quartz-arenites with ultramafic flows and sills reflects extensional tectonics in the initially stable crust (Donaldson \& de Kemp 1998).

\subsubsection{Correlative Stratigraphy}

The Archean quartz-arenites from India, Zimbabwe and Ontario share similarities with those of the Slave Province. Figure 5.6 illustrates stratigraphic sections from these Archean cratons including the Bababudan Group, the Buhawa belt, the Keeyask Lake assemblage and both the Beniah and Bell Lake formations of the Slave Province. Primarily, the lithological assemblages are identical, as each includes quartz-arenite, quartz-pebble conglomerate, heterolithic sandstone-siltstone, and banded iron-formation. In addition, the sedimentary structures indicate deposition on a shallow marine continental shelf and all examples unconformably overly a tonalitic gneissic basement, however examples of fluvial and subaerial settings are present (e.g. Bababudan Group). Mafic to ultramafic volcanic rocks are primarily found at the top of these sequences, but are also located at various stratigraphic levels, as shown for the Bababudan Group and the Keeyask Lake assemblage. 


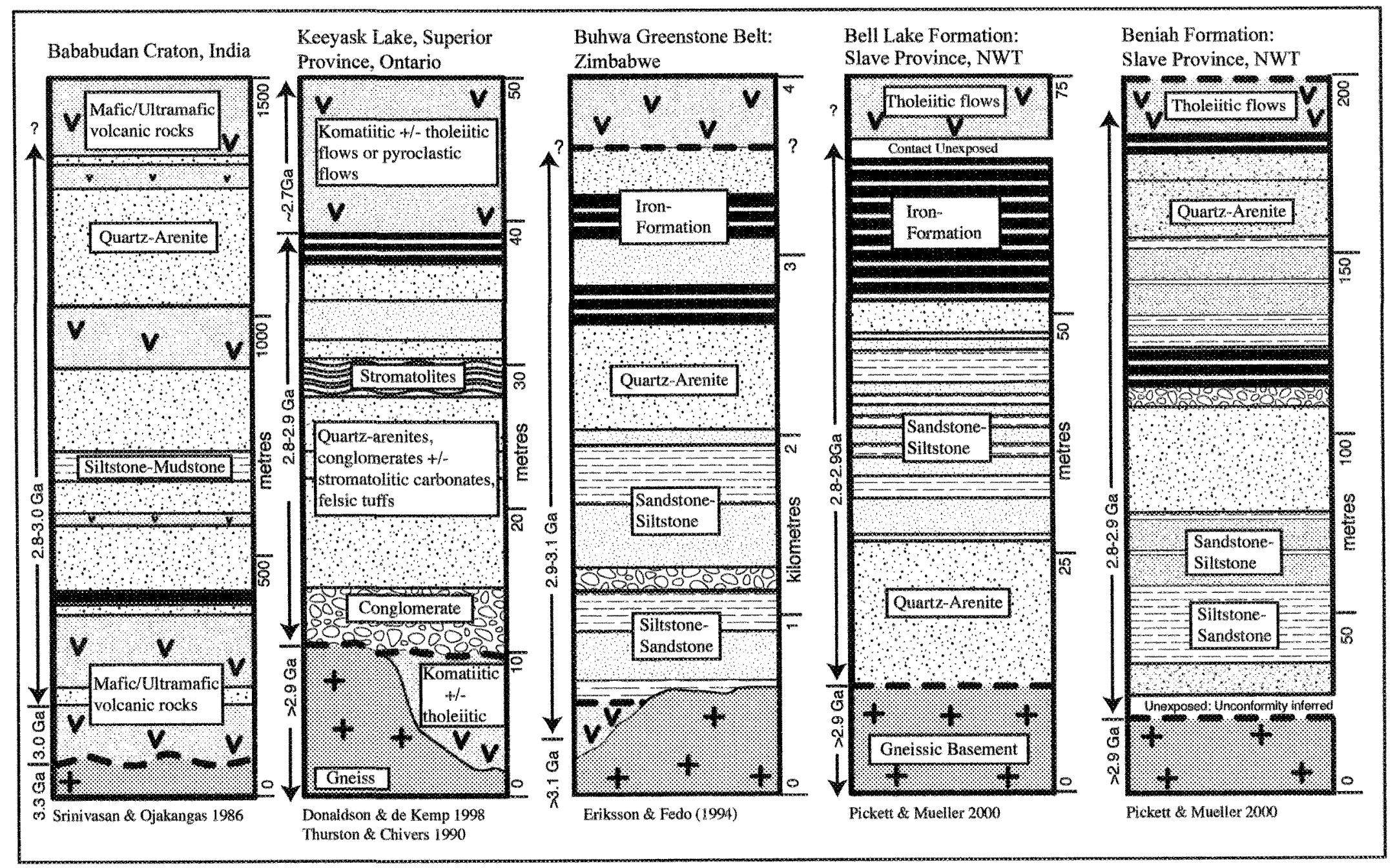

Figure 5.6. World-wide stratigraphic correlation of early Archean quartz-arenite successions and related rocks. Descriptions of the corresponding lithological units for each composite stratigraphic section can be found in the text as well as a complete reference list for each author(s). 
Contemporaneous volcanism, comparable to the mafic flows of the Beniah Formation, has been found in both the Keeyask Lake assemblage and the Bababudan Group (Donaldson \& de Kemp 1998; Eriksson \& Fedo 1994, respectively). In contrast, an unconformity/fault is interpreted to separate sedimentary from overlying volcanic rocks in the Buhwa belt. Age constraints for each of the sedimentary assemblages ranges from 2.8 to $3.0 \mathrm{Ga}$ and are concordant with the depositional age of the Beniah and Bell Lake formations. Little can be said about the similarities of sequence thickness, as the range varies from 50 to $1500 \mathrm{~m}$, with the Buhwa greenstone belt attaining a thickness of up to 4 $\mathrm{km}$.

The volcano-sedimentary sequences reflect a worldwide deposition of shallowmarine sediments atop a sialic, proto-continental crust approximately 2.9 billion years ago. Early crustal stability is indicated by the compositional maturity of the rocks, however evidence of extensional tectonics and crustal attenuation persist with the identification of abundant dyke/sill complexes and mafic to ultramafic volcanic flows towards the top of the sequences.

\subsection{Archean Climatic and Atmospheric Conditions}

Modern quartz-arenite deposits are less common than their ancient equivalents. Firstly, the necessary conditions for extreme chemical and mechanical weathering are limited to few geographic areas. Tropical latitudes provide the most favorable conditions for creating quartz-rich sands, such as those of the Orinoco River Basin, Venezuela (Johnsson et al.1988). However, precise circumstances, including humid climate, high residence times and high abrasion rates, are required (Suttner et al.1981; Pettijohn et al. 1987; Chandler 1988. Soegaard \& Eriksson 1989).

In the Archean, it is believed that an extreme climate and a closer moon orbit played considerable roles in establishing the conditions required to produce quartz-arenites (Chandler 1988; Donaldson \& de Kemp 1998; Corcoran et al. 1998, 1999). For example, elevated surface temperatures up to $85^{\circ} \mathrm{C}$ (Kasting, 1993), high $\mathrm{CO}_{2}$ (Young 1991) and a prevalent humid atmosphere (Des Marais 1994) would easily increase rates of chemical 
weathering, thus influencing sandstone composition. In addition, Corcoran et al. (1998) supported that these parameters along with high sea-level systems tracts, a proximal prominent granitic source and abundant high-energy tide- and wave- influence could create first cycle quartz-arenites in both passive, stable margins as well as in tectonically active areas. Finally, a more dynamic Earth-Moon system in the Archean greatly increased the magnitude of tides, creating tidal deposits unique to their time (Mueller et al. 2001). The alternation between high and low tides and wave reworking, resulting in elevated abrasion rates and higher net transport of grains, allowed for the accumulation of mineralogically mature sediment. Furthermore, in the absence of largely developed continents, longer wavelength fetch would produce higher amplitude shoaling waves on a platform and increase overall sediment interaction. It is proposed that the deposition and development of the Beniah Formation was influenced by a combination of these components attributing to the deposition of the Archean quartz-arenite succession.

\subsection{Conclusions}

The Beniah Formation contains mineralogically mature sedimentary rocks that were deposited in a shallow marine, shelf-type environment between 2.8 and $2.9 \mathrm{Ga}$. The sedimentary rocks were influenced predominantly by tide- and wave-activity and less so by storms, resulting in the formation of the composite bedforms during deposition. Architectural elements such as tidal channels, gravel bars and migrating sandwaves are consistent with the presence of an estuarine-embayment opening to a shoreface to offshore setting. A proposed modern setting is Chesapeake Bay, located along the east coast of the USA, in a passive margin setting. The presence of large-scale, tidally-influenced migrating sandwaves and longitudinal gravel bars are also consistent with this depositional setting.

The lithofacies and corresponding sedimentary structures of the Bell Lake Formation complement the inference of deposition along a shallow-marine shelf, although differing slightly in the fact that upward-fining, rather that upward-coarsening successions were found. The stratigraphy of the Bell Lake Formation is consistent with deposition in an open, unprotected coastal setting, giving rise to thin, extensive blankets of sandstone and 
siltstone rather than in an elaborate embayment complex as seen in the Beniah Formation sedimentary record.

Mapping along the Beniah Lake Fault zone has revealed the presence of a major unconformity between the $2.8 \mathrm{Ga}$ and the $2.6 \mathrm{Ga}$ sedimentary rocks. An outcrop in central Beniah Lake area (Location C-2) marks an unconformity between the Beniah Formation sedimentary rocks and the $2.7 \mathrm{Ga}$ volcanic rocks, analogous to the Beaulieu River Volcanic belt. The discovery of a depositional contact between volcaniclastic siltstone and mafic pillowed flows in Location B-2 indicates that locally, contemporaneous volcanism occurred during deposition of the Beniah Formation. At Bell Lake, petrography and detailed mapping have led to the confirmation that the contact between the granitic gneisses and quartz-arenites is unconformable rather than intrusive.

Lithofacies stacking in the Beniah Formation reveals several coarsening-upward successions, interpreted to reflect the attenuation of an Archean proto-continental crust under the influence of rifting and extensional tectonism as well as transgressiveprogradational events related to eustatic sea level changes. Contemporaneous volcanism, ultramafic layered complexes and abundant cross-cutting-dykes provide evidence for extension. Transgression reflects the immediate response to the extensional events adjacent to the faults that form along the proto-continental shelf. The rocks at Beniah Lake in addition to other quartz-rich sedimentary basins support crustal attenuation and a potential incipient break-up of the Slave Province ca. $2.8 \mathrm{Ga}$.

Higher $\mathrm{CO}_{2}$ levels, elevated surface temperatures and a closer orbiting moon facilitated the formation of these thick Archean quartz-arenite deposits. Deposition in a high-energy, shallow-marine environment and the erosion of quartz-rich plutonic sourcerocks were also important attributes. Archean analogues from India, Africa and other parts of Canada reveal comparable ages, as well as depositional and tectonic settings to those of the Beniah and Bell Lake formations. This indicates that the accumulation of quartzarenites on Archean proto-continents played a significant role in the Earth's early crustal evolution. 


\section{REFERENCES}

Adkins, R. M. and Eriksson, K. A. 1998. Rhythmic sedimentation in a Mid-Pennsylvanian delta-front succession, Magoffin Member (Four Corners Formation, Breathitt Group), Eastern Kentucky: A near-complete record of daily, semi-monthly, and monthly tidal periodicities. In Tidalites: Processes and Products. Edited by SEPM, Special Publication No. 61, pp. 85-94.

Allen, G. P. 1991. Sedimentary processes and facies in the Gironde estuary: a recent model for macrotidal estuarine systems. In Clastic Tidal Sedimentology. Edited by D. G. Smith, G.E. Reinson, B. A. Zaitlin and R. A. Rahmani. Canadian Society of Petroleum Geologists, pp. 349-370.

Allen, J. R. L. 1980. Sand waves: A model of origin and internal structure. Sedimentary Geology, 26; 281-328.

Allen, J. R. L. 1981. Lower Cretaceous tides revealed by cross-bedding with mud drapes. , Nature, 289; 579-581.

Ashley, G. M. 1990. Classification of large-scale subaqueous bedforms: a new look at an old problem. Journal of Sedimentary Petrology, 60: 160-172.

Bailey, E.H. and Stevens, R.E., 1960. Selective staining of K-feldspar and plagioclase on rock slabs and thin sections. The American Mineralogists: 45, pp.1020-1025.

Basu, A, Young, S. W., Suttner, L. J., James, W. C. and Mack, G. H. 1975. Re-evaluation of the use of undulatory extinction and polycrystallinity in detrital quartz for provenance interpretation. Journal of Sedimentary Petrology, 45: 873-882.

Blatt, H., Middleton, G. V. and Murray, R. C. 1980 . Origin of Sedimentary Rocks, $2^{\text {nd }}$ Edition. Prentice Hall, Englewood Cliffs, N.J.

Bleeker, W. and Ketchum, J. 1998. Central Slave Basement Complex, Northwest Territories: its autochthonous cover, décollement and structural topology. Current Research, Part C: 9-19.

Bleeker, W., Ketchum, J. F. M., Jackson, V. and Villeneuve, M. E. 1999. The Central Slave Basement Complex, Part 1: its structural topology and autochthonous cover. Canadian Journal of Earth Sciences, 36: 1-27. 
Bowring, S. A., Williams, I. S. and Compston, W. 1989. $3.96 \mathrm{Ga}$ gneisses from the Slave Province, Northwest Territories, Canada. Geology, 107: 971-975.

Chakraborty, C. and Bose, P. K. 1990. Internal structures of sandwaves in a tide-storm interactive system: Proterozoic Lower Quartzite Formation, India. Sedimentary Geology, 67: 133-142.

Chandler, F. W. 1988. Quartz arenites: review and interpretation. Sedimentary Geology, 58: $105-126$.

Chown, E. H., N'dah, E. and Mueller, W. U. 2000. The relation between iron-formation and low temperature hydrothermal alteration in an Archean volcanic environment. Precambrian Research, 101: 263-275.

Corcoran, P. L., Mueller, W. U. and Chown, E. H. 1998. Climatic and tectonic influences on fan deltas and wave-to tide-controlled shoreface deposits: evidence from the Archean Keskarrah Formation, Slave Province, Canada. Sedimentary Geology, 120: 125-152.

Corcoran, P. L., Mueller, W. U. and Padgham, W. A. 1999. Influence of tectonism and climate on lithofacies distribution and sandstone and conglomerate composition in the Archean Beaulieu Rapids Formation, Northwest Territories, Canada. Precambrian Research, 94: 175-204.

Covello, L., Roscoe, S. M., Donaldson, J. A., Roach, D. and Fyson, W. K. 1988. Archean quartz arenites and ultramafic rocks at Beniah Lake, Slave Structural Province, N.W.T. Current Research, Paper 88-1C: 223-232.

Dalrymple, R. W. 1992. Tidal Depositional Systems. In Facies Models: Response to Sea Level Change. Edited by R. G. Walker and N. P. James. Geological Association of Canada, pp. 195-218.

de Mowbray, T., and Visser, M. J. 1984. Reactivation surfaces in subtidal channel deposits, Oosterschelde, Southwest Netherlands. Journal of Sedimentary Petrology, 54: 811-824.

Des Marais, D. J. 1994. The Archean atmosphere: its composition and fate. In Archean Crustal Evolution. Edited by K. C: Condie. Elsevier; pp. 528.

Dickinson, W. R. 1980. Plate tectonics and key petrologic associations. In The continental crust and its mineral deposits. Edited by D. W. Strangway. Geological Association of Canada, Special Paper 20, pp. 341-360. 
Dickinson, W. R. and Suczek, C. A. 1979. Plate tectonics and sandstone composition. American Association of Petroleum Geologist, Bulletin, 63: 2164-2182.

Donaldson, J. A. and de Kemp, E. A. 1998. Archean quartz arenites in the Canadian Shield: examples from the Superior and Churchill Provinces. Sedimentary Geology, 120: $153-176$.

Donaldson, J. A. and Ojakangas, R. W. 1977. Orthoquartzite pebbles in Archean conglomerate, North Spirit Lake, northwestern Ontario. Canadian Journal of Earth Sciences, 14: 1980-1990.

Duke, W. L. and Prave, A. R. 1991. Storm- and tide-influenced prograding shoreline sequences in the Middle Devonian Mahantango Formation, Pennsylvania. In Clastic Tidal Sedimentology. Edited by D.G. Smith, G.E. Reinson, B. A. Zaitlin and R. A. Rahmani. Canadian Society of Petroleum Geologists, pp. 349-370.

Ehlers, T. A. and Chan, M. A. 1999. Tidal sedimentology and estuarine deposition of the Proterozoic Big Cottonwood Formation, Utah. Journal of Sedimentary Petrology, 69: 1169-1180.

Eriksson, K. A. 1977. Tidal deposits from the Archaean Moodies Group, Barberton Mountain Land, South Africa. Sedimentary Geology, 18: 257-281.

Eriksson, K. A. and Fedo, C. M. 1994. Archean synrift and stable-shelf sedimentary successions. In Archean Crustal Evolution. Edited by K. C. Condie. pp. 171-204.

Eriksson, K. A., Krapez, B. and Fralick, P. W. 1994. Sedimentology of Archean greenstone belts: signatures of tectonic evolution. Earth-Science Reviews, 37: 1-88.

Fedo, C. M. and Eriksson, K. A. 1996. Stratigraphic framework of the $-3.0 \mathrm{Ga}$ Buhwa Greenstone Belt: a unique stable-shelf succession in the Zimbabwe Archean Craton. Precambrian Research, 77: 161-178.

Ferree, R. A., Jordan, D. W., Kertes, R. S., Savage, K. M. and Potter, P. E. 1988. Comparative petrographic maturity of river and beach sand, and origin of quartz arenites. Journal of Geological Education, 36: 79-85.

Folk, R. L. 1980. Petrology of Sedimentary Rocks. Hemphill Publishing Co., pp.184.

Foscolos, A. E. 1990. Catagenesis of argillaceous sedimentary rocks. In Diagenesis. Edited by I. A. Mcllreath and D. W. Morrow. Geoscience Canada, Reprint Series 4 pp. 177187. 
Fralick, P. and Barrett, T. J. 1995. Depositional controls on iron formation associations in Canada. In Sedimentary Facies Analysis. Edited by A. G. Plint. Blackwell Science, pp. 137-156.

George, A. D. 1994. Tidal sedimentation in part of the Late Silurian Grampians Basin, Southeastern Australia. Journal of Sedimentary Research, B64: 311-325.

Hamblin, A. P. and Walker, R. G. 1979. Storm-dominated shallow marine deposits: the Fernie-Kootenay (Jurassic) transition, southern Rocky Mountains. Canadian Journal of Earth Sciences, 16: 1673-1690.

Harms, J. C., Southard, J. B., Spearing, D. R. and Walker, R. G. 1975. Depositional environments as interpreted from primary sedimentary structures and stratification sequences. Short Course Notes, Society of Economic Paleontologists and Mineralogists, pp. 161.

Hart, B. S. and Plint, A. G. 1995. Gravelly shoreface and beachface deposits. In Sedimentary Facies Analysis, Edited by A. G. Plint. Blackwell Science, pp. 75-99.

Hartly, A. J. 1993. Sedimentological response of an alluvial system to source area tectonism: the Seilao Member of the Late Cretaceous to Eocene Purilactic Formation of northern Chile. In Tectonic Controls and Signatures in Sedimentary Successions. Edited by L. E. Frostick and R. J. Steel. International Association of Sedimentologists, pp. 489-500.

Hawkensworth, C. J., Moorbath, S., O'Nions, R. K. and Wilson, J. F. 1975. Age relationships between greenstone belts and 'granites' in the Rhodesian Archean craton. Earth and Planetary Science Letters, 25: 251-262.

Helmstaedt, H. and Padgham, W. 1986. A new look at the stratigraphy of the Yellowknife Supergroup at Yellowknife, N.W.T.- implications for the age of gold -bearing shear zones and Archean basin evolution. Canadian Journal of Earth Sciences, 23: 454 475.

Helmstaedt, H., Padgham, W. A. and Brophy, J. 1986. Multiple dikes in Lower Kam Group, Yellowknife greenstone belt: Evidence for Archean sea-floor spreading? Geology, 14: 562-566.

Henderson, J. B. 1970. Stratigraphy of the Yellowknife Supergroup, Yellowknife BayProsperous Lake area, District of Mackenzie. Geological Survey of Canada Paper, 70-26: 1-12. 
Henderson, J. B. 1975. Sedimentology of the Archean Yellowknife Supergroup at Yellowknife, District of Mackenzie. Geological Survey of Canada Bulletin, 246: 162.

Henderson, J. B. 1981. Archean basin evolution. In Precambrian Plate Tectonics. Edited by A. Kröner. Elsevier, pp. 213-235.

Henderson, J. B. 1985. Geology of the Yellowknife-Hearne Lake area, District of Mackenzie. Geological Survey of Canada Memoir, 414: 135.

Henderson, J. B., van Breemen, O. and Loveridge, W. D. 1987. Some U-Pb zircon ages from Archean basement, supracrustal and intrusive rocks, Yellowknife-Hearne Lake area, District of Mackenzie. Geological Survey of Canada Bulletin, 114: 111-121.

Homewood, P. and Allen, P. 1981. Wave-,tide-, and current-controlled sandbodies of Miocene Molasse, Western Switzerland. AAPG Bulletin, 65: 2534-2545.

Hrabi, R. B., Grant, J. W., Godin, P. D., Helmstaedt, H. and King, J. E. 1993. Geology of the Winter Lake supracrustal belt, central Slave Province, District of Mackenzie, Northwest Territories. Current Research, Paper 93-1C: 71-81.

Hrabi, R. B. and Helmstaedt, H. 1994. Diverse metavolcanic sequences and late sedimentary deposits: Implications for early and late tectonic evolution in the Winter Lake belt. In Exploration Overview 1994 Northwest Territories; Mining, Exploration and Geological Investigation. Edited by R. Kusick and S. P. Goff, pp. 38.

Isachsen, C. E. and Bowring, S. A. 1994. Evolution of the Slave craton. Geology, 22: 917-920.

Isachsen, C. E. and Bowring, S. A. 1997. The Bell Lake group and Anton Complex: a basement-cover sequence beneath the Archean Yellowknife greenstone belt revealed and implicated in greenstone belt formation. Canadian Journal of Earth Sciences, 34: 169-189.

Isachsen, C. E., Bowring, S. A. and Padgham, W. A. 1991. U-Pb zircon geochronology of the Yellowknife volcanic belt, NWT, Canada. Journal of Geology, 99: 55-67.

Jackson, V. A. 1996. Preliminary Geology of part of the Lower Supracrustal Succession in the Bell Lake Area (85 J/16). Map EGS 1996-17. Department of Indian Affairs and Northern Development, Yellowknife, NWT. 
James, D. T. and Mortensen, J. K. 1992. An Archean metamorphic core complex in the southern Slave Province: basement-cover structural relations between the Sleepy Dragon Complex and the Yellowknife Supergroup. Canadian Journal of Earth Sciences, 29: 2133-2145.

Johnson, H. D. and Baldwin, C. T. 1996. Shallow clastic seas. In Sedimentary Environments: Processes, Facies and Stratigraphy. Edited by H. G. Reading. Blackwell Science Ltd., pp. 232-280.

Johnson, H. D. and Levell, B. K. 1995. Sedimentology of a transgressive, estuarine sand complex: the Lower Cretaceous Woburn Sands (Lower Greensand), southern England. In Sedimentary Facies Analysis. Edited by A. G. Plint. Blackwell Science, pp. 17-46.

Johnsson, M. J., Stallard, R. F. and Meade, R. H. 1988. First-cycle quartz arenites in the Orinoco river basin, Venezuela and Columbia. Joumal of Geology, 96: 263-277.

Kasting, J. F. 1993. Earth's early atmosphere. Science, 259: 920-926.

Klein, G. 1970. Tidal origin of a Precambrian quartzite- The lower fine-grained quartzite (Middle Dalradian) of Islay, Scotland. Journal of Sedimentary Petrology, 40: 973983.

Kusky, T. M. 1990. Evidence for Archean ocean opening and closing in the Southern Slave Province. Tectonics, 9: 1533-1563.

Laird, M. G. 1995. Coarse-grained lacustrine fan-delta deposits (Pororari Group) of the northwestern South Island, New Zealand: evidence for Mid-Cretaceous rifting. In Sedimentary Facies Analysis. Edited by A. G. Plint. International Association of Sedimentology, pp. 197-217.

Lambert, M., B. Ernst, R. E. and Dudas, F. O. L. 1992. Archean mafic dyke swarms near the Cameron River and Beaulieu River volcanic belts and their implications for tectonic modeling of the Slave Province, Northwest Territories. Canadian Journal of Earth Sciences, 29: 2226-2248.

Maclachlan, K. and Helmstaedt, H. 1993. The relationships between the Dwyer and Chan Formations and the Anton Granite, Yellowknife Greenstone Belt: implications for the origin of gabbroic rocks in the Chan Formation. Queen's University, EGS 1993-06, pp. 9.

MacLachlan, K. and Helmstaedt, H. 1995. Geology and geochemistry of an Archean mafic dike complex in the Chan Formation: basis for a revised plate-tectonic model 
of the Yellowknife greenstone belt. Canadian Journal of Earth Sciences, 32: 614 630.

Miller, D. J. and Eriksson, K. A. 1997 Late Mississippian prodeltaic rhythmites in the Appalachian basin: A hierarchal record of tidal and climatic periodicities. Journal of Sedimentary Research, 67: 653-660.

Mortensen, J. K., Henderson, J. B., Jackson, V. A. and Padgham, W. A. 1992. U-Pb geochronology of Yellowknife Supergroup felsic volcanic rocks in the Russell Lake and Clan Lake areas, southwestern Slave Province, N.W.T. Geological Survey of Canada Paper, 91-2: 1-7.

Mueller, W. U., Corcoran, P. L. and Donaldson, J. A. 2001. Sedimentology of a tideinfluenced high energy Archean coastline: The Jackson Lake Formation, Slave Province, Canada. International Association of Sedimentology. In Press.

Mueller, W. U., Corcoran, P. L. and Eriksson, P. G. 1998. Volcanic and pyroclastic rocks: recognition, depositional processes and implications for massive sulfide exploration. Short Course Notes; UQAC, Dalhousie University, and Pretoria University, $21 \mathrm{p}$.

Mueller, W. U. and Donaldson, J. A. 1994. Sedimentology of the late-orogenic sedimentary Jackson Lake Formation in the Slave Province. Indian and Northern Affairs Development, pp. 1-13.

Mueller, W. and Dimroth, E. 1987. A terrestrial-shallow marine transition in the Archean Opemisca Group east of Chapais, Quebec. Precambrian Research, 37: 29-55.

Nio, S.-D. and Yang, C.-S. 1991. Diagnostic attributes of clastic tidal deposits: a review. In Clastic Tidal Sedimentology. Edited by D.G.Smith, G. E. Reinson, B. A. Zaitlin, and R. A. Rahmani. Canadian Society of Petroleum Geologists, pp. 3-28.

Northrup, C. J., Isachsen, C., Bowring, S. A. 1997. Tectonic evolution of the Point Lake greenstone belt: insights from U-Pb geochronology and $\mathrm{Sm}-\mathrm{Nd}$ isotope geochemistry, GAC/MAC Abstract Volume, Ottawa, 1997, pp. A-109.

Northrup, C. J., Isachsen, C. and Bowring, S. A. 1998. Tectonic evolution of the Point Lake greenstone belt and adjacent gneisses, central Slave craton, N.W.T., Canada. Canadian Journal of Earth Sciences, 36: 1043-1059.

Okazaki, H. and Masuda, F. 1995. Sequence stratigraphy of the late Pleistocene PalaeoTokyo Bay: barrier islands and associated tidal delta and inlet. In Tidal Signatures in Modern and Ancient Sediments. Edited by B. W. Flemming and A. Bartholomä. Blackwell Science, pp. 275-288. 
Padgham, W. A. 1983. Gold deposits in the Northwest Territories, $11^{\text {th }}$ Geoscience Forum, DIAND, Yellowknife, NWT.

Padgham, W. A. and Fyson, W. K. 1992. The Slave Province: a distinct Archean craton. Canadian Journal of Earth Sciences, 29: 2072-2086.

Pettijohn, F. J., Otter, P. E. and Siever, R. 1987. Sand and Sandstone. Springer-Verlag, pp. 176-186.

Pickett, C. and Mueller, W.U. 2000. Lithofacies characteristics and petrography of stable Archean shelf sequences: Slave Province, NWT. In Cook, F. and Erdmer, P. (compilers). Slave-Northern Cordillera Lithospheric Evolution (SNORCLE) Transect and Cordilleran Tectonics Workshop meeting (Feb. 25-27), University of Calgary, Lithoprobe Report No. 72, pp. 11-24.

Plint, A G., Eyles, N. and Walker, W. 1992. Controls of sea level change. In Facies Models: Response to Sea Level Change. Edited by R. G.Walker and N. P James. Geological Association of Canada, pp. 15-25.

Prave, A. R., Duke, W. S. and Slattery, W. 1996. A depositional model for storm- and tide-influenced prograding siliciclastic shorelines from the Middle Devonian of the central Appalachian foreland basin, USA. Sedimentology, 43: 611-629.

Prothero, D. R. and Schwab, F. 1996. Sedimentary Geology. W.H. Freeman and Co., pp. 575.

Raymond, L. A. 1995. Igneous Petrology. In Petrology: The Study of Igneous, Sedimentary and Metamorphic Rocks. Edited by J. L. Hahn. Wm. C. Brown Publishers, pp. 262.

Reading, H. G. and Collinson, J. D. 1996. Clastic coasts. In Sedimentary Environments: Processes, Facies and Stratigraphy. Edited by H. G. Reading. Blackwell Science Ltd., pp. 154-231.

Reineck, H.E. and Singh, I.B. 1980. Depositional Sedimentary Environments. Springer, Heidelberg, pp. 549.

Relf, C., Chouinard, A., Sandeman, H. and Villeneuve, M.E. 1994. Contact relationships between the Anialik River volcanic belt and the Kanguyyak gneiss belt, northwestern Slave Province, N.W.T.; In Current Research, Part C, Geological Survey of Canada, Paper 94-C: 49-59. 
Rice, R. J., Long, D. G. F., Fyson, W. K. and Roscoe, S. M. 1990. Sedimentological evaluation of three Archean metaquartzite- and conglomerate-bearing sequences in the Slave Province, N.W.T.; In Current Research, Part C, Geological Survey of Canada, Paper 90-1C: 305-322.

Roach, D. 1990. Geology of the Beniah Lake Area. Indian and Northern Affairs Canada, EGS 1990-2.

Roach, D. and Fyson, W. K. 1992. The geology of the Beniah Lake area, Slave Structural Province. Ottawa-Carleton Geoscience Centre, Open File Report \# 2484, Geological Survey of Canada, pp. 47-50.

Rollinson, H. G. 1994. Using Geochemical Data: Evaluation, Presentation, Interpretation. Longman Scientific \& Technical, pp. 352.

Roscoe, S. M., Stubley, M. and Roach, D. 1989. Archean quartz arenites and pyritic paleoplacers in the Beaulieu River supracrustal belt, Slave Structural Province, N.W.T. Current Research, Part C, Geological Survey of Canada, Paper 89-1C: 199214.

Roscoe, S. M. 1990. Quartzose arenites and possible paleoplacers in Slave Structural Province, N.W.T. In Current Research, Part C, Geological Survey of Canada, Paper 90-1C: 231-238.

Rust, B. R. and Koster, E. H. 1984. Coarse alluvial deposits. In: Facies Models. Edited by R. G. Walker. Geoscience Canada, Reprint Series, pp. 53-69

Simonson, B. M. 1984. High-energy shelf deposits: Early Proterozoic Wishart Formation, Northeast Canada. The Society of Economic Paleontologists and Mineralogists, 251268.

Simpson, E. L. and Eriksson, K. A. 1991. Depositional facies and controls on parasequence development in siliclastic tidal deposits from the Lower Proterozoic, upper Mount Guide Quartzite, Mount Isa Inlier, Australia. In Clastic Tidal Sedimentology. Edited by D.G.Smith, G. E. Reinson, B. A. Zaitlinand and R. A. Rahmani. Canadian Society of Petroleum Geologists, pp. 371-387.

Soegaard, K. and Eriksson, K. A. 1989. Origin of thick, first-cycle quartz arenite successions: Evidence from the $1.7 \mathrm{Ga}$ Ortega Group, Northern New Mexico. Precambrian Research, 43: 129-141. 
Soegaard, K. and Eriksson, K. A. 1985. Evidence of tide, storm, and wave interaction on a Precambrian siliciclastic shelf: The 1700 M.Y. Ortega Group, New Mexico. Journal of Sedimentary Petrology, 55; 672-684.

Srinivasan, R. and Ojakangas, R. W. 1986. Sedimentology of quartz-pebble conglomerates and quartzites of the Archean Bababudan Group, Dharwar Craton, South India: Evidence for early crustal stability. Journal of Geology, 94: 199-214.

Strachan, R. A. 1986. Shallow marine sedimentation in the Proterozoic Moine succession, Northern Scotland. Precambrian Research, 32: 17-33.

Streckeisen, A. 1979. Classification and nomenclature of volcanic rocks, lamprophyres, carbonatites, and melilitic rocks; recommendations and suggestions of the IUGS Subcommission on the Systematics of Igneous Rocks. Geology, 7: 331-335.

Stubley, M. P. 1997. Geological compilation of the Carp Lake Area. NTS 85P adn southeastern 850. Map EGS 1997-07, Department of Indian Affairs and Northern Development, Yellowknife, NWT.

Stubley, M. P. and Befin, N. J. 1993. Geology of the Smokey Lake area, southern Slave Province (parts of NTS 85P/3 and 6). Map EGS 1993-5. Department of Indian Affairs and Northern Development, Yellowknife, NWT.

Suttner, L. J., Basu, A. and Mack, G. H. 1981. Climate and the origin of quartz arenites. Journal of Sedimentary Petrology, 51: 1235-1246.

Taylor, P. N., Kramers, J. D., Moorbath, S., Wilson, J. F., J.L., O. and Martin, A. 1991. $\mathrm{Pb} / \mathrm{Pb}, \mathrm{Sm}-\mathrm{Nd}$ and $\mathrm{Rb}-\mathrm{Sr}$ geochronology in the Archean Craton of Zimbabwe. Chemical Geology, 87: 175-196.

Thurston, P. C. and Chivers, K. M. 1990. Secular variation in greenstone sequence development emphasizing Superior Province, Canada. Precambrian Research, 46: 21-58.

van Breemen, O., Davis, W. J. and King, J. E. 1992. Temporal distribution of granitoid plutonic rocks in the Archean Slave Province, northwest Canadian Shield. Canadian Journal of Earth Sciences, 29: 2186-2199.

Van Wagoner, J. C., Mitchum, R. M., Campion, K. M., and Rahmanian, V. D. 1990. Siliciclastic Sequence Stratigraphy in Well Logs, Cores, and Outcrops: Concepts for 
High-Resolution Correlation of Time and Facies. In AAPG Methods in Exploration Series, N0. 7. The American Association of Petroleum Geologists, pp. 55.

Villeneuve, M. E. 1994. Correlating within and between Slave Province greenstone belts using U-Pb dating. Exploration Overview 1994, Northwest Territories, DIAND, pp. 60 .

Viser, M. J. 1980. Neap-spring cycles reflected in Holocene subtidal large-scale bedform deposits: a preliminary note. Geology, 8: 542-546.

Walker, R. G. 1992. Facies, facies models and modern stratigraphic concepts. In Facies Models: Response to Sea Level Change. Edited by R. G.Walker and N. P James. Geological Association of Canada, pp. 1-14.

Walker, R. G. and Plint, A. G. 1992. Wave- and storm-dominated shallow marine systems. In Facies Models: Response to Sea Level Change. Edited by R. G.Walker and N. P James. Geological Association of Canada, pp. 219-238.

Williams, H., Turner, F. J. and Gilbert, C. M. 1982. Petrography, An Introduction to the Study of Rocks in Thin-Section.W.H. Freeman and Co., pp. 626.

Williams, H., Turner, F. J. and Gilbert, C. M. 1954. Petrology. W. H. Freeman, pp.406.

Young, G. M. 1991. The geological record of glaciation: revelance to the climatic history of the Earth. Geoscience Canada, 18: 100-108. 